PNL-3853

UC-63

\title{
Photovoltaic Product Directory and Buyers Guide
}

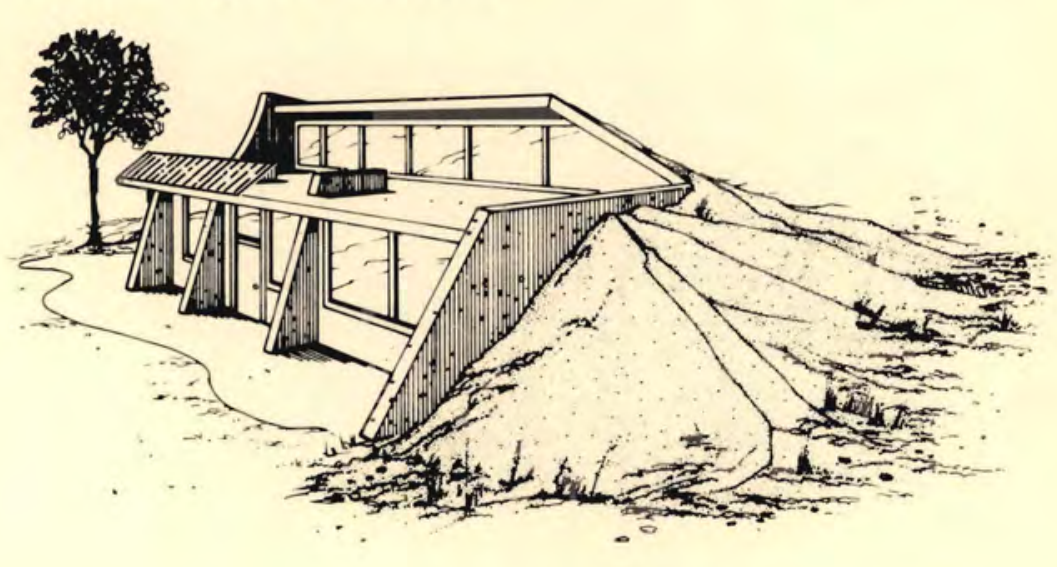

June 1981

Prepared in association with the Solar Energy Industries Association for the U.S. Department of Energy under Contract DE-AC06-76RLO 1830

Pacific Northwest Laboratory Operated for the U.S. Department of Energy by Battelle Memorial Institute 


\section{DISCLAIMER}

This document was prepared as an account of work sponsored by an agency of the United States Government. Neither the United States Government nor Battelle Memorial Institute nor any of their employees, makes any warranty, express or implied, or assumes any legal liability or responsibility for the accuracy, completeness, or usefulness of any information, apparatus, product, or process disclosed, or represents that its use would not infringe privately owned rights. Reference herein to any specific commercial products, process, or service by trade name, trademark, manufacturer, or otherwise, does not necessarily constitute or imply its endorsement, recommendation, or favoring by the United States Government or Battelle Memorial Institute. The views and opinions of authors expressed herein do not necessarily state or reflect those of the United States Government thereof, and shall not be used for advertising or product endorsement purposes.

\section{PACIFIC NORTHWEST LABORATORY operated by \\ BATTELLE \\ for the \\ UNITED STATES DEPARTMENT OF ENERGY \\ Under Contract DE-AC06-76RLO 1830}

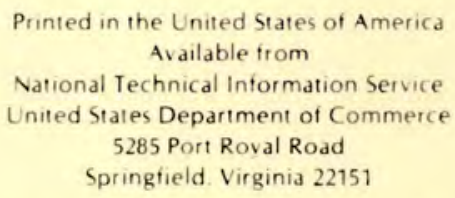

- Pages Setling Price

$\begin{array}{lr}001-025 & \$ 4.00 \\ 026-050 & \$ 4.50 \\ 051-075 & \$ 5.25 \\ 076-100 & \$ 6.00 \\ 101-125 & \$ 6.50 \\ 126-150 & \$ 7.25 \\ 151-175 & \$ 8.00 \\ 176-200 & \$ 9.00 \\ 201-225 & \$ 9.25 \\ 226-250 & \$ 9.50 \\ 251-275 & \$ 10.75 \\ 276-300 & \$ 11.00\end{array}$


PHOTOVOLTAIC PRODUCT DIRECTORY AND BUYERS GUIDE

R. L. Watts

S. A. Smith

R. P. Mazzucchi

June 1981

Prepared for

the U.S. Department of Energy

under Contract DE-AC06-76RL0 1830

Pacific Northwest Laboratory

Richland, Washington 99352 
The authors wish to acknowledge the support, encouragement and contributions of a number of individuals and organizations associated with the Department of Energy Photovoltaic Program and the photovoltaics industry.

At the Department of Energy, ideas and funding were contributed by the staff of the Photovoltaics Division including Andrew Krantz, Elaine Smith and Paul Macock. Planning assistance and support were given by George Tenet, Ray Kendall and the PV executive council of the Photovoltaics Division of the Solar Energy Industries Association.

We would also like to express our appreciation to John Hesse and the Jet Propulsion Laboratory staff and John Bozek of NASA Lewis Research Center and to Robert Koontz, Tom West, and Peter Thompson of SERI for reviewing the draft.

We would also like to thank Roger Baird, Clem Bloomster, Ted Blumenstock, Bob Brown, Bill Brussear, Richard Campbell, Molly Craven, Jim Cullen, Dennis Delans, Joh Eckel, Candy Eliason, Rita Harrington, Mike Keeling, Brian Kennedy, Bill Lamb, Jo-Mari Lett, Vic Luke, Bob McGinnis, Stephen Madigan, Jim Marler, Jim Merrill, Mike Nelson, Jim Padula, K. V. Ravi, Vince Rice, Rob Robinson, Rick Scott, Ishaq Sharayer, Jim Skane, Diane Smith, Bob Stewart, Ron Strathman, Sam Taylor, Mary Trigg, Fritz Wald, Bob Walker, Vern Weekman, John Wurmser, and Jack Zohar. 
PREFACE

Photovoltaic (PV) generation of electricity marks the dawn of a new energy era. In total silence PV systems remarkabley and simply convert light directly into electricity. This electricity powers the tools of civilization from the mountain tops to the seas and into the far reaches of outer space. It is now possible to build a home anywhere you desire or even travel to the moon and have the conveniences of a secure and reliable PV power supply. In recognition of the energy savings potential of PV systems for terrestrial applications, the Department of Energy in conjunction with industry has conducted research and development to accelerate price reductions and product adaptation. This effort has succeeded brilliantly, bringing this space age dream down to earth so that in many applications it is now cost effective to use PV energy supplies.

Photovoltaics are providing energy for an ever growing number of applications worldwide. More than ten thousand residences now use PV power to provide for daily electrical needs. Vacation chalets and remote residences enjoy the advantages of simple and easily maintained PV power supplies. More than ten thousand navigational beacons and warning lights, using stored photovoltaic power, provide safe passage for ships and aircraft. The list of viable applications continues to grow as inventive thinkers ponder the possibilities of PV technology. Although it is not yet cost-effective to use PV electricity as if it were provided by a central utility, there are many applications where PV is now the most cost effective and reliable power supply. Where utility lines are difficult to access or where energy management and lifestyle changes conserve electricity, PV systems are viable today. PV systems are also particularly useful for applications where portability is desired or where energy needs coincide with solar intensity for such applications as ventilating and water pumping.

The information presented in this directory should be of interest to a wide audience, for it describes products and appliances that can be used in or on the home, farm, or factory, as well as on the road or seas and in remote areas of the great outdoors. Reliable and cost-effective PV powered products are available for those who are willing to seek out and apply them. This directory is intended to help you decide whether or not currently marketed photovoltaic products are appropriate for your needs. 
1.0 INTRODUCTION

2.0 BACKGROUND INFORMATION ON ELECTRICITY AND PHOTOVOLTAICS • $\quad 2.1$

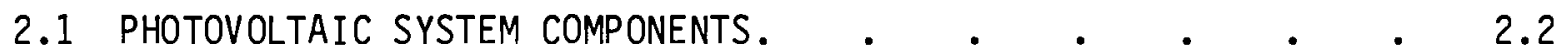

2.2 ELECTRICAL DEFINITIONS.$\quad \cdot \quad \cdot \quad \cdot \quad \cdot \quad \cdot \quad \cdot \quad \cdot \quad \cdot \quad \cdot \quad \cdot 3$

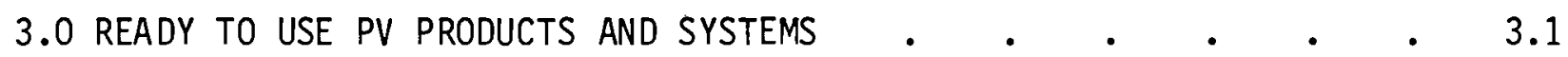

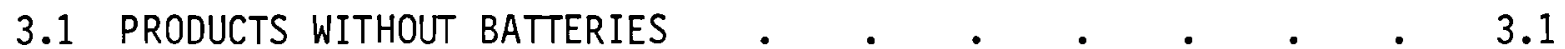

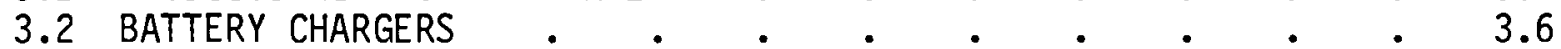

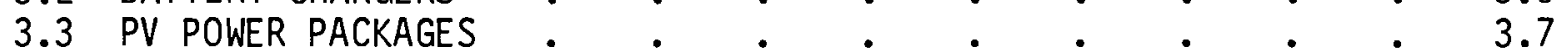

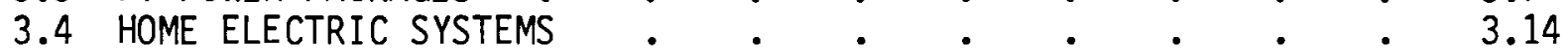

3.5 SYSTEMS WITHOUT BATTERIES. $. \quad . \quad . \quad \cdot \quad \cdot \quad \cdot \quad \cdot 3.14$

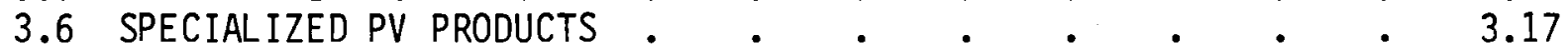

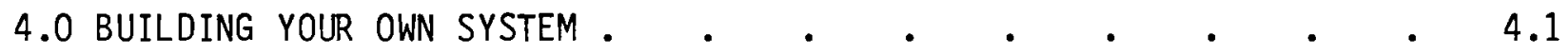

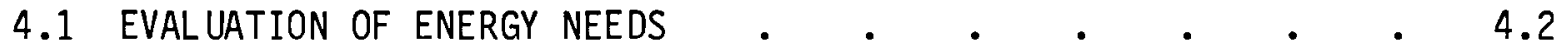

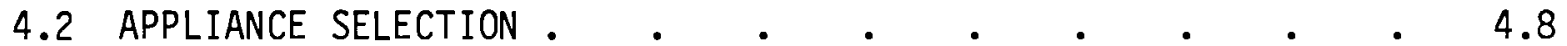

4.3 ARRAY SIZING AND SELECTION $\cdot$ •

4.4 BATTERY SIZING AND SELECTION.$\quad \cdot \quad \cdot \quad \cdot \quad \cdot \quad \cdot \quad \cdot \quad 4.19$

4.5 SELECTING POWER CONDITIONING EQUIPMENT $\cdot . \quad \cdot \quad \cdot \quad \cdot 4.24$

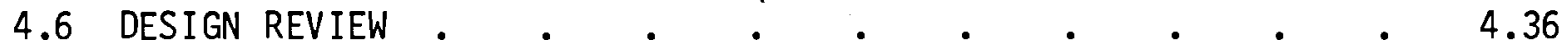

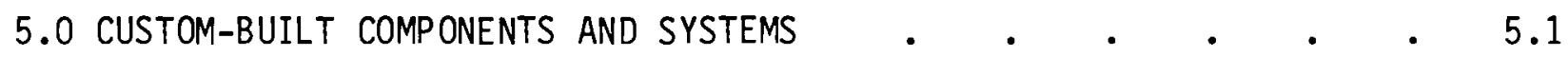

5.1 CUSTOM SYSTEMS CURRENTLY IN OPERATION $\quad . \quad \cdot \quad \cdot \quad \cdot \quad \cdot 5.1$

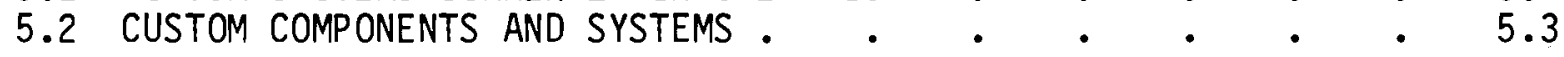

6.0 WHEN TO CHOOSE PV . . . . . . . . . . . . . . 6.1

6.1 WHERE PV CLEARLY MAKES SENSE . . . . . . . . . 6.2

6.2 WHERE PV MAY MAKE SENSE $\cdot \quad \cdot \quad \cdot \quad \cdot \quad \cdot \quad \cdot \quad \cdot \quad \cdot 6.7$

6.3 PURCHASING A PV SYSTEM $\quad \cdot \quad \cdot \quad \cdot \quad \cdot \quad \cdot \quad \cdot \quad \cdot \quad \cdot 6.23$

7.0 USER EXPERIENCES WITH PHOTOVOLTAICS $\quad . \quad \cdot \quad \cdot \quad \cdot \quad \cdot \quad \cdot \quad 7.1$

7.1 SOUTHERN CALIFORNIA INSTALLATIONS $\quad \cdot \quad \cdot \quad \cdot \quad \cdot \quad \cdot \quad \cdot \quad 7.1$

7.2 NORTHERN CALIFORNIA INSTALLATIONS $\cdot \quad \cdot \quad \cdot \quad \cdot \quad \cdot \quad \cdot 7.8$

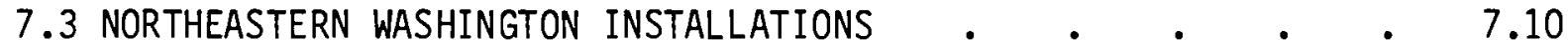

7.4 SUMMARY OF USER EXPERIENCES WITH PV.$\quad \cdot \quad \cdot \quad \cdot \quad \cdot \quad \cdot 7.17$

APPENDIX I

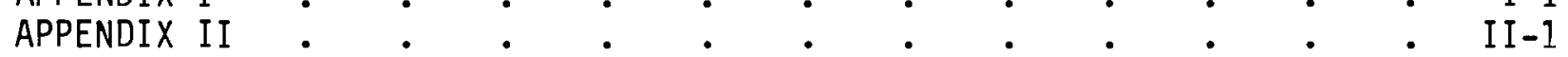

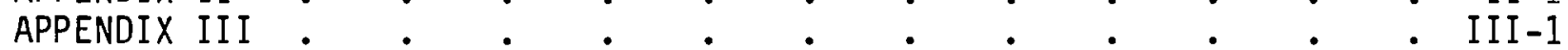

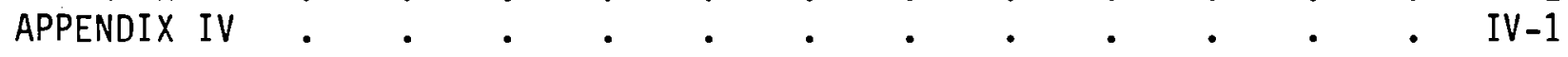




\subsection{INTRODUCTION}

A major obstacle to the widespread acceptance and use of photovoltaics (PV) has been the lack of practical information on how these systems work, and the types of systems and products available in 1981. The purpose of this directory is to provide up-to-date information on the PV industry in a form that you can easily use in becoming better acquainted with PV. The directory also includes as complete a listing as possible of the sources of PV products as of the spring of 1981. This directory/buyer's guide includes material to explain the language (used in the industry), the operation, design guidelines, and approximate list prices of currently available PV systems and their components.

The directory/buyer's guide is intended to be a comprehensive compilation of PV products, applications, and manufacturers. The focus is to identify and discuss PV products and system components that can be purchased off-the-shelf or ordered from catalogs that are available as of the spring of 1981 . The discussions are written from your perspective as a potential buyer and are intended to reveal products that can meet your needs. Of course, the information should also be of value to manufacturers as it identifies opportunities to meet developing market demands.

The format of the directory has been selected to provide help for anyone interested in PV, while providing an organization which can be easily referenced by professionals in the field. The directory/buyer's guide is organized to:

- help you understand photovoltaic systems (Chapter 2),

o show what is available off-the-shelf and help you start to use it (Chapter 3),

- design your own system if you are more daring, and to help you select from available products, (Chapter 4),

- direct you to sources for expert help for the challenging applications (Chapter 5),

- help you decide if PV products can meet your needs (Chapter 6), and

o provide information on actual PV user experiences (Chapter 7). In addition to the text, we have included four appendices to provide more detailed information in the following areas: 
o information on various financial incentives available from state and federal governments (Appendix I),

- sources of additional information on photovoltaics (Appendix II),

- a matrix indicating the sources of various types of PV products (Appendix III), and

o a listing of the addresses of PV product suppliers (Appendix IV).

The material presented is based upon information from publications and programs sponsored by the Department of Energy, responses to an inquiry of PV product manufacturers, and publications from private entities. A literature search of material dealing with PV manufacturers, products, and projects yielded leads on information in the first and third categories. The information from the second category resulted from announcements in the trade press publicizing the compilation of the directory, and inquiries mailed to all identified entities producing photovoltaic products or products amenable to PV power supplies. Once a draft of the catalog was completed, four workshops were held in Washington D.C., Boston, Phoenix and Los Angeles, to ensure that all product information is accurate and up to date.

Some firms have undoubtedly been overlooked due to the rapid growth of the industry. Since we have made efforts which far exceed those that most potential purchasers would exercise to identify PV products, we feel justified in asserting that this directory is comprehensive. We have painstakingly attempted to contact all firms listed in directories prepared by the Solar Energy Industries Association, Department of Energy, Solar Energy Research Institute, Solar Engineering Magazine, and the Solar Age Resource Guide, among others. Firms that have been overlooked are requested to contact the authors to insure that they will be included in the next update.

A11 of the information on products contained in this directory has been assembled on the basis of catalogs and data sheets submitted to us by PV suppliers. Since it is not within the scope of this effort to test and verify claims by manufacturers, we recommend that purchasers obtain additional information from PV users, suppliers, and other reliable sources. Reputable product suppliers often offer warranties and maintain lists of satisified customers for substanciation of their claims. Neither Battelle nor the government recommends the purchase or use of any specific product or supplier. 


\subsection{BACKGROUND INFORMATION ON ELECTRICITY AND PHOTOVOLTAICS}

This chapter is intended to introduce PV technology and provide basic information useful for readers who are unfamiliar with PV energy systems. After briefly summarizing the historical development of photovoltaics, we provide a description of the building blocks of a PV system. Finally a short glossary of electrical terms is included to help you in understanding the operation and specification of PV products.

The derivation of the term "photovoltaic" is from two Latin words: "photo" meaning of, or produced by, light; and "voltaic" meaning of, or producing, an electric current and voltage. Photovoltaic, or solar cell, technology is an exciting alternative source of energy that converts sunlight directly into electricity without any moving parts. Photovoltaic systems operate efficiently in a wide range of applications including small, low-power devices for remote communication instruments; mid-size systems for residences and schools; and large power systems for high-demand operation.

Vigorous efforts are under way within the Department of Energy's National Photovoltaic Program to increase the number of PV systems installed across the country. These installations, which are discussed in Chapter 5, promote greater public awareness of the practicality of PV, fortify confidence in their use, and help stimulate growth of the industry. Industry growth and better manufacturing techniques have dramatically improved the economic attractiveness of PV. Continued encouragement of PV power generation will aid in the orderly transition from an economy based on fossil fuel to one founded on alternative sources of energy.

In 1954, scientists at Bell Laboratories reported an improved solar cell that enabled PV technology to be used as a practical energy source. The primary use of solar cells was to power spacecraft equipment. In 1975, ERDA began a research and development program to hasten production of solar cells and promote their use. The program has grown to include hundreds of scientists who work in industry, universities, and laboratories across the country and has brought about significant advancements in efficiency, durability, and system cost effectiveness. 
Today, most of the reliable and inexpensive solar cells are made of singlecrystal silicon. Silicon is the second most abundant element on earth. It is found, for example, in various kinds of sand. After an extensive purification process, silicon crystals are "grown" and then cut into slices to form the basis of the solar cells. When sunlight strikes the solar cell, internal electrons are energized and electricity is generated. Useful electricity is drawn off through wires attached to the cells. (a)

\subsection{PHOTOVOLTAIC SYSTEM COMPONENTS}

The following material provides brief definitions of the components in a typical PV system. Not all PV systems have or need all of these components, but they are introduced here for your information.

Photovoltaic Cells are discs or squares of specially treated silicon (or other material) that generate a voltage, when exposed to light.
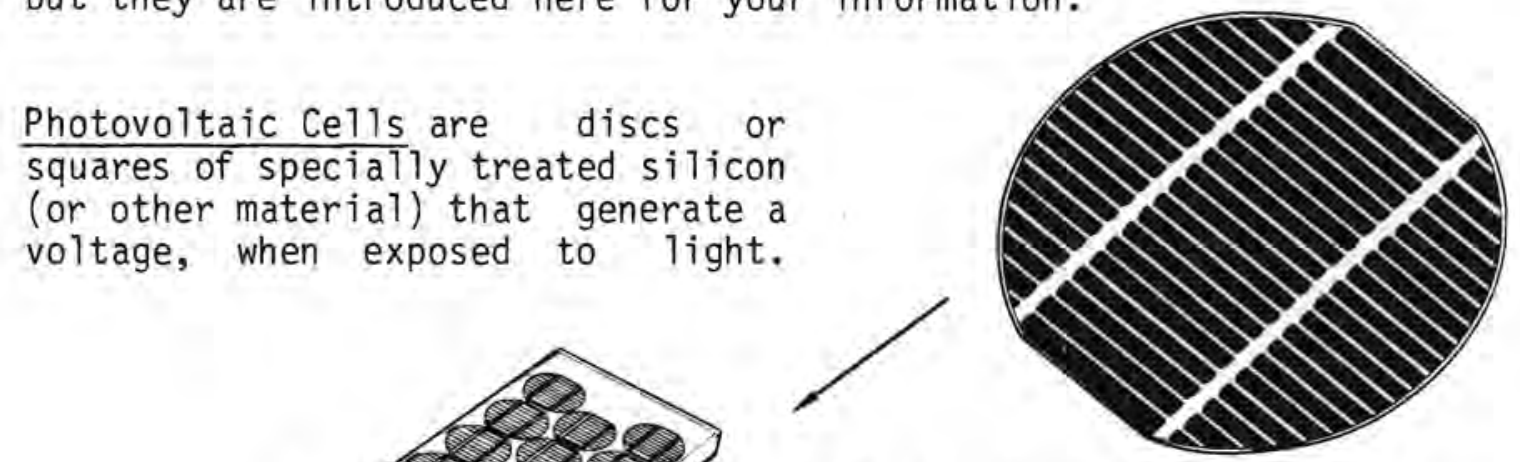

Photovoltaic Modules contain a number of PV cells that are encapsulated (sealed) between metal and transparent plates. Modules are either flatplates or use special designs to concentrate the sunlight on the cells. The electrical output of the modules depends on the efficiency and number of cells.

A Photovoltaic Array is a group of PV modules connected together to produce a predetermined voltage for either energy storage or to be used directly (without energy storage) by a direct current DC appliance.

(a) Solar Energy Research Institute 1980. Photovoltaics Solar Electric Power Systems. SERI/SP-433-487. Golden, Colorado. 


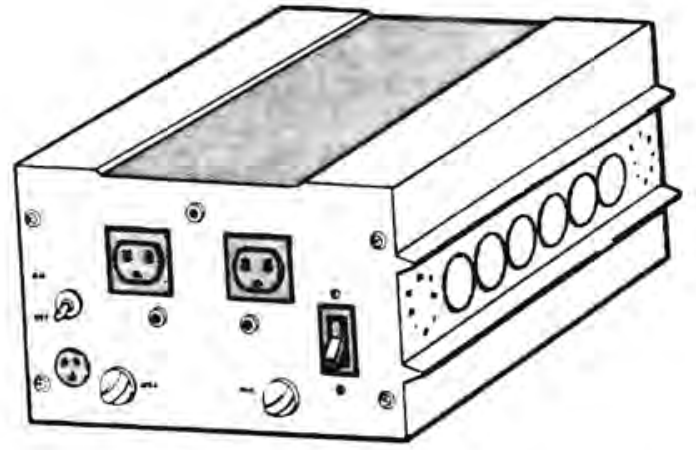

Charge Controllers protect the battery system from both excessive charge and discharge.

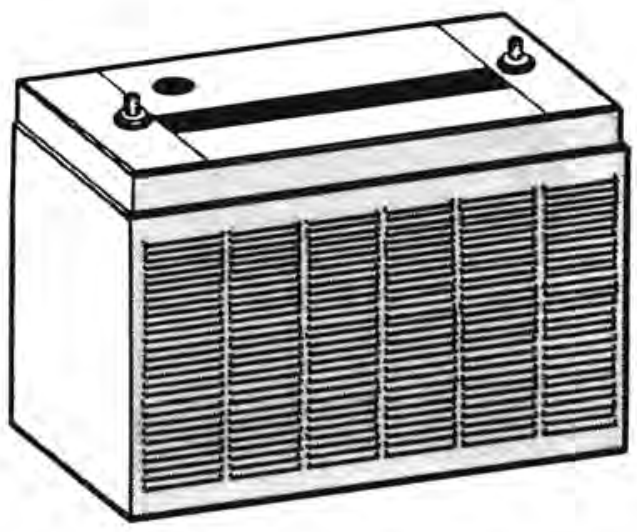

End-Use equipment (i.e., load) can be selected from a wide variety of $A C$ and $D C$ products including fluorescent lights, refrigerators, pumps, fans, etc.
Inverters change the direct current (DC) produced by the cells or stored in the batteries to alternating current ( $A C)$ for use with $A C$ products and app 1 i ances.

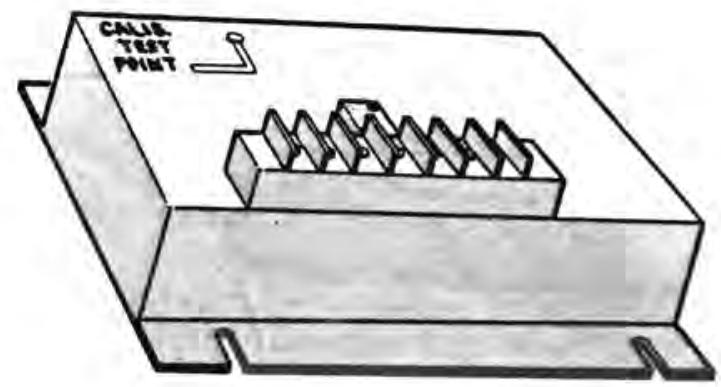

Energy Storage is usually done with lead acid batteries. The type and size depend on the requirements of the specific application.

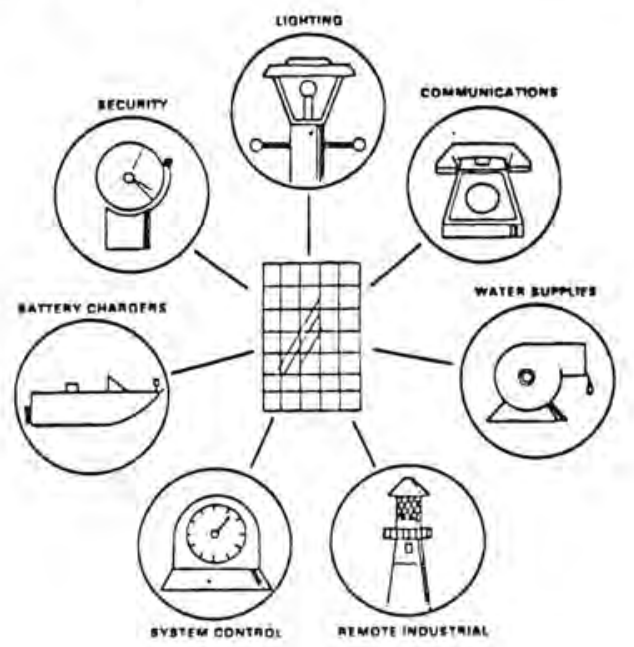

\subsection{ELECTRICAL DEFINITIONS}

If you are the type of person who frequently reads Electrical World, and knows the difference between ampere, volt, watt, power and energy, you can skip this section. In this section we provide definitions of some of the basic elements of electricity. This information will help you in reading catalogs 
supplied by PV manufacturers/distributors, and it will help you when expressing your energy needs to these people.

Ampere (A) is a standard unit of current. It is the rate of flow of a charge past a given point in an electrical circuit. This is analogous to the quantity of water passing by a given point in a garden hose. The two types of electrical current are direct $(D C)$ and alternating $(A C)$. It is not really that important to know the specific details of these currents, only that some products/ appliances operate strictly on DC or AC and some, such as portable TV sets, and certain universal (brush type) motors can run on either.

Lumen (1m) is a measurement of the amount of light produced by an incandescent or fluorescent light bulb. A $100 \mathrm{~W}$ incandescent light bulb produces about 2000 lumens of light.

Voltage $(V)$ is a measurement of potential difference between two points or an electromotive force. In layman's terms it is the force that causes the current to flow through a wire. Most automobile batteries are either 6 or 12 volts.

Watt $(W)$ is a unit of power. One watt is the amount of power that is supplied when a current of one ampere is driven by a potential difference (i.e., force) of one volt. If you look at a typical light bulb, it will state that it requires 25, 50, or $100 \mathrm{~W}$ of power to operate. A watt is not a measurement of the amount of light given off by a light bulb.

Watt-Hour (Wh) is a unit of energy measured as the product of power (i.e., one watt) and time (one hour). If a $25 \mathrm{~W}$ light bulb is operated for one hour, it will use 25 Wh of electricity.

Ampere-Hour (Ah) is sometimes used as a unit of energy where voltage is fairly constant. For instance, storage batteries have a fairly constant voltage and are frequently rated in terms of ampere hours of capacity. Similarly, an electric clock requires a fairly constant current and its energy requirements can also be specified in Ah. Ampere-hours can be changed to watt hours by multiplying by the voltage of the system. In a $6 \mathrm{~V}$ system with 2 Ah of capacity, the total would be $6 \times 2=12$ WATT HOURS of energy. In a $12 \mathrm{~V}$ system with 2 Ah of capacity, there would be 24 WATT HOURS of energy. 


\subsection{READY TO USE PV PRODUCTS AND SYSTEMS}

This chapter is written for people who want the conveniences of modern electric living and a) own recreational vehicles or water craft, b) own a remote retreat home or live in a locality where there is no dependable utility, or c) who would like to achieve a measure of energy independence using a renewable energy resource. It is also written for farmers, industrialists, and construction worker who wish to use electrical or electronic equipment away from power lines. One can watch television, read at night, wash clothes, drink pure water, keep food and medicines fresh, and stay cool in hot weather by using products that are powered by photovoltaics without dependence on an electric utility system. Remote communications, corrosion protection, crop irrigation and stock watering are other examples of modern PV use.

The following sections give an idea of the various types of PV products and systems currently available off-the-shelf.. These PV systems are pre-engineered to meet specific end uses and include all the components necessary to be placed into immediate service. The PV systems have been sorted into five categories which are: Products Without Batteries, Battery Chargers, Power Packages, Home Electric Systems, and Partial Systems. For each we discuss typical applications and list the available products. Approximate prices are of ten given but in an age of continuing inflation, they can quickly be out of date.

\subsection{PRODUCTS WITHOUT BATTERIES}

Some electrical needs occur, or can be shifted to occur, only when the sun shines. Such applications are termed "sun synchronous" and do not require the use of storage batteries. Energy for cooling work and living areas, and irrigation pumping are ideal candidates for PV power supplies. Such items as attic fans, casa blanca fans, evaporative coolers for RV's and residences, circulating pumps for solar hot water heaters, and domestic or agricultural water pumps are available with PV power supplies.

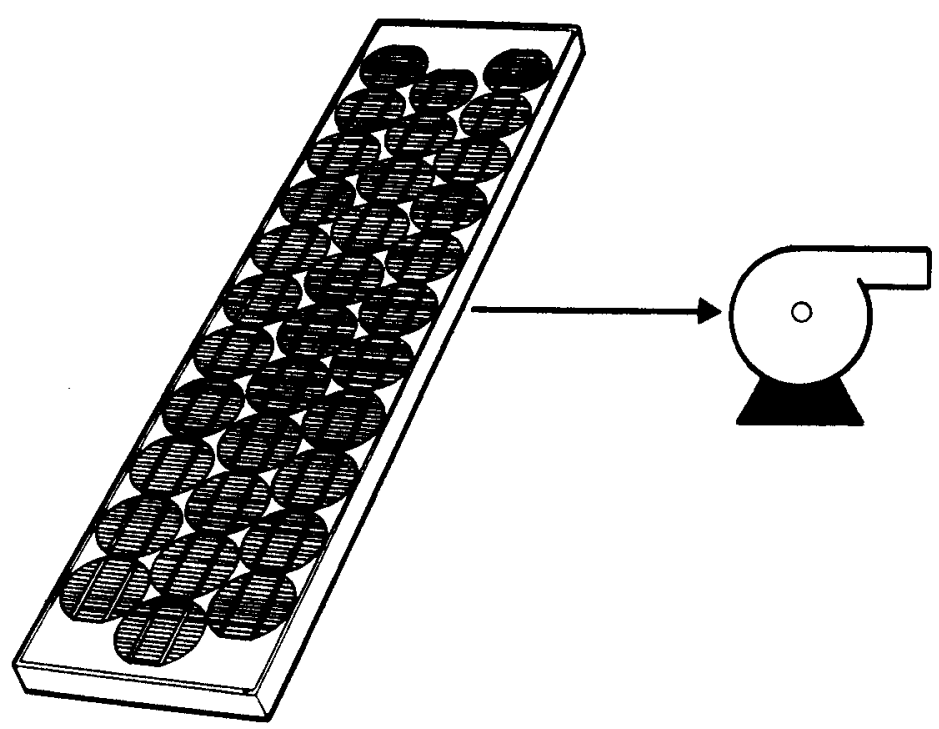


These are efficient PV applications because the output of the arrays is immediately utilized to the desired end. For example, PV powere dexhaust fans installed in buildings, vehicles, and boats are used to prevent overheating -the more intensely the sun shines, the more rapidly the fan removes excess heat. Furthermore, these systems are the most maintenance free and long-lived because of their inherent simplicity and freedom from electical storage requirements. Table 3.1 lists some of the commercial fans available.

TABLE 3.1. PV Powered Fans and Vents

\begin{tabular}{|c|c|c|c|c|}
\hline $\begin{array}{c}\text { Item } \\
\text { Catalog No. }\end{array}$ & Description & Company & Rating & $\begin{array}{l}\text { Approx. } \\
\text { List } \\
\text { Price } \\
\end{array}$ \\
\hline Solar Vent "SV" & $\begin{array}{l}\text { Replacement for } 12 " \\
\text { Wind Turbine Roof } \\
\text { Vent }\end{array}$ & $\begin{array}{l}\text { Braden Wire } \\
\& \text { Metal } \\
\text { Products }\end{array}$ & $N A *$ & $\$ 225.00$ \\
\hline $\begin{array}{l}\text { Parmak Solar } \\
\text { Vent Fan }\end{array}$ & Attic Fan & Parker McCrory & $N A^{*}$ & $\$ 298.95$ \\
\hline Solar Breeze & $\begin{array}{l}\text { 12" diameter Fan with } \\
\text { Matched PV Module }\end{array}$ & Photowatt & 500 CFM & \\
\hline Solar-Turbin & $\begin{array}{l}\text { Sun or wind powered } \\
\text { Ventilation Fan }\end{array}$ & Photowatt & 1400 CFM & \\
\hline Solar Fan & $\begin{array}{l}\text { Solar Powered Attic } \\
\text { Fan \#138 }\end{array}$ & $\begin{array}{l}\text { Solar Thermal } \\
\text { Inc. }\end{array}$ & $\begin{array}{l}800-1400 \\
\text { CFM in } \\
\text { attic use }\end{array}$ & \\
\hline The Solarvent & $\begin{array}{l}\text { Sunpowered Ventilating } \\
\text { Fan. 5-Blade 8" Dia- } \\
\text { meter Aluminum Fan }\end{array}$ & Solarex Corp. & $\begin{array}{l}250 \text { CFM } \\
6 \text { Watt } \\
4-60 \\
\text { Unipanel }\end{array}$ & $\$ 299.95$ \\
\hline $\begin{array}{l}\text { Solar Attic } \\
\text { Fan PVF 1204A }\end{array}$ & $\begin{array}{l}\text { 3-Blade Fan for Vent } \\
\text { Use in Buildings \& } \\
\text { Attics }\end{array}$ & $\begin{array}{l}\text { United Energy } \\
\text { Corp. }\end{array}$ & 3.6 Watts & \\
\hline $\begin{array}{l}\text { Solar Ceiling } \\
\text { Fan PVF } 1212 C\end{array}$ & $\begin{array}{l}\text { 3-Blade Fan of "Casa } \\
\text { Blanca" Type }\end{array}$ & $\begin{array}{l}\text { United Energy } \\
\text { Corporation }\end{array}$ & 20.3 Watts & \\
\hline Casa Blanca Fan & 3 blade "Casa Blance" & $\begin{array}{l}\text { WM Lamb Co. \& } \\
\text { Energy House }\end{array}$ & $2000 \mathrm{cfm}$ & $\$ 465$ \\
\hline
\end{tabular}


One attractive feature of these fans is that they can be retrofitted to existing buildings by the handyman without shock or fire hazard, often at a lower cost than connecting to the building power supply. In addition, controllers are unnecessary since the array automatically fulfills the control requirements. Thus, they are frequently installed in houses that actually have utility power available.

Another product contributing to living comfort is the photovoltaic-powered evaporative cooler for cooling recreational vehicles and residences. The three sizes presently available with matched PV power supplies are listed in Table 3.2.

A PV powered circulating pump for a conventional solar collector can improve system performance and reliability. It does this by circulating the fluid rapidly through the collector, when the sun is at full brightness, and pumps slowly, when the sun is partly obscured. This "proportional control" is said to enhance the efficiency of a solar water heating system by as much as $15 \%$ above that possible from conventional systems that use household current and temperature sensitive instruments to provide system control.

TABLE 3.2 Evaporative Coolers with Matched PV Power Supplies

\begin{tabular}{|c|c|c|c|c|}
\hline Item & Description & Company & Rating & $\begin{array}{l}\text { Approx. } \\
\text { List } \\
\text { Price }\end{array}$ \\
\hline RV Cooler & $\begin{array}{l}\text { LA-8 } \\
\text { RV Evaporator Cooler } \\
\text { with } 2 \text { ASI 16-2000 } \\
\text { panels }\end{array}$ & $\begin{array}{l}\text { Wm Lamb Co. \& } \\
\text { Energy House }\end{array}$ & 600 CFM & $\$ 1470$ \\
\hline $\begin{array}{l}\text { Evaporator } \\
\text { Cooler }\end{array}$ & $\begin{array}{l}\text { LA-9 } \\
\text { Residential Evaporative } \\
\text { Cooler with } 2 \text { ASI-16- } \\
2000 \text { Solar Panels }\end{array}$ & $\begin{array}{l}\text { Wm Lamb Co. \& } \\
\text { Energy House }\end{array}$ & 1200 CFM & $\$ 1375$ \\
\hline $\begin{array}{l}\text { Residential } \\
\text { Evaporative } \\
\text { Cooler }\end{array}$ & $\begin{array}{l}\text { Residential Evaporative } \\
\text { Cooler Using DC Motors } \\
\text { with } 450 \mathrm{~W} \text { of ASI 16- } \\
2000 \text { Solar Panels }\end{array}$ & $\begin{array}{l}\text { Wm Lamb Co. \& } \\
\text { Energy House }\end{array}$ & $\begin{array}{l}5000 \text { CFM } \\
1 / 2 \text { hp fan } \\
\text { Motor With } \\
\text { Circulating } \\
\text { Pump }\end{array}$ & $\$ 7200$ \\
\hline
\end{tabular}


Some pumps available for this purpose with matched PV modules are listed in Table 3.3.

Another practical sun synchronous application is the pumping of water for irrigation and other uses into storage tanks or directly onto the land. Systems that are available from Applied Solar Energy/Solar Electric International and Rainbird are shown in Table 3.4.

An additional system is available from Energy House and Wm. Lamb Co. for deep well pumping. This unit is designed for residential and stock watering applications or for providing water for campsites and golf courses. It uses the tested lift jack principle used on windmills for decades with a $1 / 2 \mathrm{hp} D C$ motor located on the ground surface. The design is adaptable to lifts to $80^{\prime}$

\section{TABLE 3.3 Low Flow Rate PV Pump Systems}

\begin{tabular}{|c|c|c|c|c|}
\hline Item \& Catalog No. & Description & Company & Rating & $\begin{array}{l}\text { Approx. } \\
\text { List } \\
\text { Price }\end{array}$ \\
\hline $\begin{array}{l}\text { Circulating Pumps } \\
\text { Model } 1500 \& 8200\end{array}$ & $\begin{array}{l}\text { DC pump w/match- } \\
\text { ing PV array }\end{array}$ & $\begin{array}{l}\text { A.Y. McDonald } \\
\text { Mfg. Co. }\end{array}$ & $\begin{array}{l}200 \text { Watts } \\
\text { and larger } \\
\text { pumps }\end{array}$ & $\begin{array}{l}\$ 2500 \\
\text { and up }\end{array}$ \\
\hline PV Power Pak & $\begin{array}{l}\text { 1-30 Watt Panel } \\
\& \text { Circulating } \\
\text { Pump }\end{array}$ & $\begin{array}{l}\text { Mid Pacific } \\
\text { Solar Corp. }\end{array}$ & 33 Watt Pump & $\$ 500$ \\
\hline PV Power Pak \#1000 & $\begin{array}{l}\text { 1-20 Watt Pane } 1 \& \\
\text { Circulating Pump }\end{array}$ & Solar Disc & $\begin{array}{l}20 \text { Watt Pane } 1 \\
\& \text { Circulating } \\
\text { Pump }\end{array}$ & $\$ 400$ \\
\hline PV Power Pak \#1500 & $\begin{array}{l}\text { 1-30 Watt Panel \& } \\
\text { Circulating Pump }\end{array}$ & Solar Disc & $\begin{array}{l}30 \text { Watt Panel } \\
\& \text { Circulating } \\
\text { Pump }\end{array}$ & $\$ 500$ \\
\hline $\begin{array}{l}\text { Hot Water Circulator } \\
12 \text { DC-2 }\end{array}$ & $\begin{array}{l}\text { 2-20 Watt \#1212 } \\
\text { PV Modules }\end{array}$ & $\begin{array}{l}\text { United Energy } \\
\text { Corp. }\end{array}$ & $\begin{array}{l}11 \mathrm{ft} \text { of head } \\
5 \mathrm{gpm}\end{array}$ & \\
\hline $\begin{array}{l}\text { Hot Water Circulator } \\
24 \text { DC } 2\end{array}$ & $\begin{array}{l}2-20 \text { W \#1212 } \\
\text { PV Modules }\end{array}$ & $\begin{array}{l}\text { United Energy } \\
\text { Corp. }\end{array}$ & $\begin{array}{l}11 \mathrm{ft} \text { of head } \\
5 \mathrm{gpm}\end{array}$ & \\
\hline $\begin{array}{l}\text { Hot Water Circulator } \\
\text { \#12 OC1 }\end{array}$ & $\begin{array}{l}1-20 \text { Watt \#1212 } \\
\text { PV Module \& } \\
\text { Circulating Pump }\end{array}$ & $\begin{array}{l}\text { United Energy } \\
\text { Corp. }\end{array}$ & $\begin{array}{l}4 \mathrm{ft} \text { of head } \\
3 \mathrm{gpm}\end{array}$ & \\
\hline
\end{tabular}




\section{TABLE 3.4 Medium and High Flow Rate Water Pumps with Matched PV Power Supply}

Name of Product

A. Y. McDonald

Remote pumping system.

Models $8200 \& 1500$ for

high capacity \& high

heat applications.

SE I-SUn Pump

Model 250M (medium lift:

$2.51 \mathrm{t} / \mathrm{sec}(4.5 \mathrm{~m})$

Model 250L (low lift:

$61 \mathrm{t} / \mathrm{sec} 2 \mathrm{~m})$

Emergency Water Supply Package

Rain Bird

Irrigation Pumping

System Model CSB 33B

Irrigation Pumping System CSB 50B for medium head applications for low head application

\author{
Specifications
}

Single \& dual impeller, selfpriming centrifugal pumpina systems using DC motors. Systems connect directly to solar array or battery.

The lightweight, portable Sun Pump is a self-contained system comprising a 250-watt PV array, a pumpset, a Maximum Power Controller (MPC), and a mount ing frame. It is particularly well suited for use in rural areas and other places not served by an electric grid.

Designed to provide safe drinking water for up to 5,000 people from lake, stream, or open well. The system includes a PV-powered pump, a chlorinator and 2 25,000-litre collapsible storage tanks.

$1 / 3$ HP single stage self priming centrifugal pumping system with DC motor \& long life brushes $396 \mathrm{~W}$ solar array. Incl. battelies, controls support hdwe. \& wiring.

(a $15^{\prime}-20^{\prime}$ Head Typical

30 - 45 GPM capacity

$1 / 2$ HP single stage self priming centrifugal system WDC motor \& long life brushes, $528 \mathrm{~W}$ solar array, Incl. batteries Rontrols support hdwe. \& wiring.

(a 20' - 30' Head.

$35-45$ GPM

Irrigation Pumping System CSB $100 B$ for medium head applications

CSB $150 \mathrm{~B}$

CSB $200 B$
$1 \mathrm{HP}$ single stage self priming centrifugal system with $D C$ motor long life brushes 1,056 $\mathrm{W}$. Array incl. batteries, cohtrols, support hdwe. \& wiring. D.0. ExC. $11 / 2 \mathrm{HP}$ and $1584 \mathrm{~W}_{\mathrm{p}}$
array.

0.0. Exc. 2.0 HP

$\$ 2,112 W^{2}$ array

a $40^{\circ}$ - $50^{\prime}$ Head

45 - 90 GPM
Approx. Price

$\$ 4,900-\$ 20,000$

(with array,

support hard-

ware and

wiring).

$\$ 6,250$ for single units; quant ity discounts

available

$\$ 10,000$

$\$ 8,115$

To Delete

Batteries \&

Controls

order CSB

330

a $\$ 5,691$

$\$ 9,480.75$

To Delete

Batteries \&

Controls Order

CSB 50D

(A) $\$ 7,326.75$.

$\$ 16,962.75$

To Delete

Batteries \&

Controls

Order CSB 1000

a $13,929.75$

$\$ 22,917$

To Delete

Batteries \&

Controls

Order CSB 1500

(a 19,884

$\$ 30,035.25$

To Delete

Batteries \&

Controls.

CSB 2000

(A) $\$ 26,123.25$ 
or less and up to about $380^{\prime}$ with correspondingly reduced flow (the greater lift is accompanied by reduced flow). Contact Wm Lamb or Energy House for fu11 details on this system that sells for about $\$ 6,650$.

The TriSolarCorp makes a variety of custom designed pumping systems. Their pumping systems utilize a special power matching circuit with improved pumping efficiency in the morning and afternoon.

\subsection{BATTERY CHARGERS}

Sun-powered battery chargers can be added to an existing battery powered appliance or system to provide additional power and to maintain batteries at a high charge level. PV powered battery chargers are available in a variety of sizes and voltages to match the battery. For as little as $\$ 20$ one can purchase a charger for 3,6 or 9 volt nickel cadmium (flashlight size) batteries. Much larger systems are available for industrial or recreational use. Currentiy marketed battery charger systems are listed in

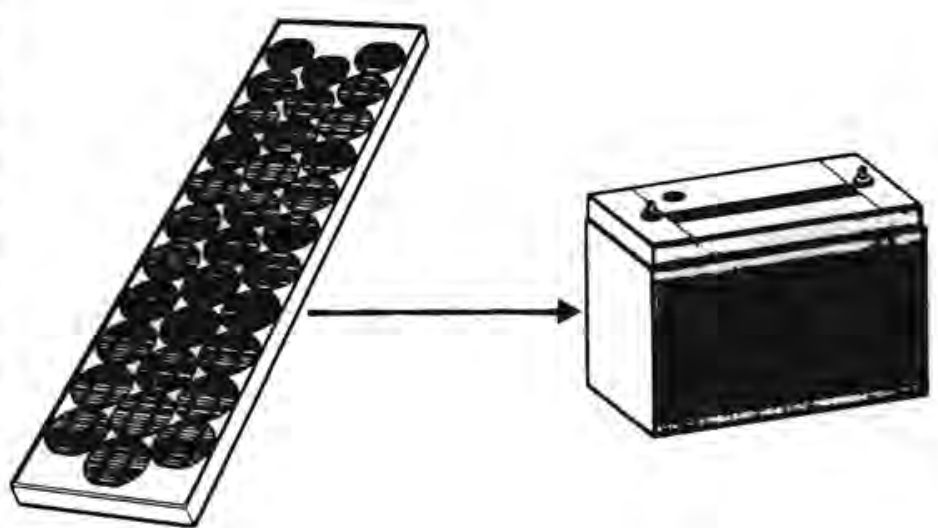
Table 3.5.

In instances where a backup generator is available, it isn't absolutely essential to size the PV battery charger precisely. You can start with a small PV unit and add more modules if desired. One caution here is in order - you may save money by buying one charge controller large enough to handle the final complement of modules you may desire. Adding PV modules would then be fairly simple so long as the rated capacity of the charge controller and wiring is not exceeded, and the batteries charging rate is not exceeded. 
TABLE 3.5. PV Powered Battery Chargers

\begin{tabular}{|c|c|c|c|c|c|}
\hline Application & $\begin{array}{c}\text { Supplier } \\
\text { Description } \\
\end{array}$ & $\begin{array}{l}\text { Catalog } \\
\text { Number } \\
\end{array}$ & Rating & $\begin{array}{l}\text { Charge } \\
\text { Controller } \\
\end{array}$ & $\begin{array}{l}\text { Approx. } \\
\$ \text { List* } \\
\end{array}$ \\
\hline $\begin{array}{l}\text { Rechargeable } \\
\text { Flashlight }\end{array}$ & Energy House & $\begin{array}{l}\text { Sunstor } \\
\text { Jr. }\end{array}$ & $\begin{array}{l}\text { AA-3-5 hr } \\
\text { C 6-10 hr } \\
\text { D } 8-12 \mathrm{hr}\end{array}$ & Not Needed & $\$ 12.50$ \\
\hline Nicad Pack & $\begin{array}{l}\text { Solarex, } \\
\text { Multivolt }\end{array}$ & 5520400 & $\begin{array}{l}50 \text { ma } 3 \text {, } \\
6 \text { or } 9 \mathrm{~V}\end{array}$ & Not Needed & $\$ 20$ \\
\hline Boats \& RVs & $\begin{array}{l}\text { Solarex, } \\
\text { Marine }\end{array}$ & $\begin{array}{l}1270 \text { MP } \\
\text { HE51MP }\end{array}$ & $\begin{array}{l}0.65 \mathrm{~A} \text { O } \\
12 \mathrm{~V} / 2.1 \mathrm{~A} \\
014 \mathrm{~V}\end{array}$ & Included & $\$ 445$ \\
\hline$"$ & $\begin{array}{l}\text { Free Energy } \\
\text { Systems Marine } \\
\text { can be walked } \\
\text { on when mountec }\end{array}$ & $\begin{array}{l}12-33 \mathrm{SL} \\
129 \mathrm{SL}\end{array}$ & $\begin{array}{l}2.0 \mathrm{~A} 0 \\
14 \mathrm{~V} / 0.6 \mathrm{~A} \\
014 \mathrm{~V}\end{array}$ & $\begin{array}{ll}\text { BVR } & 12-2 \\
\text { BVR } & 12-07\end{array}$ & \\
\hline$"$ & $\begin{array}{l}\text { United Energy } \\
\text { Corporation }\end{array}$ & $\begin{array}{l}1204 \\
1212\end{array}$ & $\begin{array}{l}0.3 \text { \& } 12 \mathrm{~V} \\
1.1 \mathrm{~A} \text { \& } 12 \mathrm{~V}\end{array}$ & $\begin{array}{l}\text { Not Needed? } \\
\text { Not Needed? }\end{array}$ & \\
\hline $\begin{array}{l}\text { Marine } \\
\text { Environment }\end{array}$ & $\begin{array}{l}\text { Tideland Sig- } \\
\text { nal Hermeti- } \\
\text { cally sealed } \\
\text { in glass }\end{array}$ & MG 600 & $0.6 \mathrm{~A} @ 6 \mathrm{~V}$ & $\begin{array}{l}\text { Not Needed } \\
\text { with pure } \\
\text { lead batteries }\end{array}$ & \\
\hline
\end{tabular}

*For panel including blocking diode and charge controller if needed.

\subsection{PV POWER PACKAGES}

PV power packages consist of panels, storage batteries, and power conditioning equipment. These systems are available from a variety of sources in many sizes. Their performance depends upon the type of electrical needs and the amount of sunshine available.

Two basic types of power packages are available -- those that provide direct current (DC) only and those that also provide alternating current $(A C)$. The major difference between the systems is the presence of an "inverter" which converts $D C$ into $A C$ power. Due to the power requirement of the inverter, $A C$ systems are significantly less efficient than their $D C$ counterparts. For more detailed information on inverter efficiencies the reader is directed to Section 4.5 . 
When selecting a PV power package there are several key issues to consider in addition to whether $A C$ or $D C$ power is needed. These include:
$0 \quad$ the expected peak load
0 the average energy requirements
0 the expected climate conditions
0 the required system reliability

The storage and power conditioning systems must be large enough to handle the maximum or peak load. In the case of $A C$ power, this usually occurs when induction motors are started -- check the "surge" power requirements. In the case of DC power, it is the sum of the appliance ratings which will be used at the same time. Not only must this peak be met by storage, but the daily and seasonal average power requirements must be considered to insure that the batteries are maintained at a satisfactory level of charge.

Two climatic factors are of primary importance; the expected levels of solar insolation (sunshine intensity), and the expected temperature extremes. Obviously the amount of sunshine available will dictate the size of the PV array. Temperature is important since it affects the performance of the array and the storage systems. If freezing conditions are expected the batteries must be suitably protected.

Finally, the issue of system reliability requirements must be considered. If power is needed for essential uses such as navigational or safety lighting, the system must be oversized to insure that sufficient power is available under any circumstances such as extended cloudy periods. PV systems for such applications should be discussed with a supplier who understands potential liability risks. On the other hand, if the system is used for recreational purposes or intermittent applications,oversizing might not be economically attractive. The sizing of PV power packages must be done properly. A report by NASA Lewis, DOE/NASA/0195-81/1 "PV Stand Alone Systems Preliminary Engineering Design Handbook" will be helpful in this task. A preliminary or "first out" sizing procedure is outlined in Chapter 4. 


\subsubsection{Power Packages}

Most suppliers of PV modules have sold a sizeable number of custom designed DC power packages, but at present, only a few maintain an inventory of standard systems or and sent catalog sheets. Most module manufacturers will assist potential purchasers design and specify a PV system to meet personal needs. However, this section considers only those systems available off-the-shelf. The purchaser of a DC power system must keep in mind that many common $A C$ home appliances cannot be used without purchasing a DC to AC inverter. There are, however, a growing number of DC appliances which are discussed in Section 4.2.

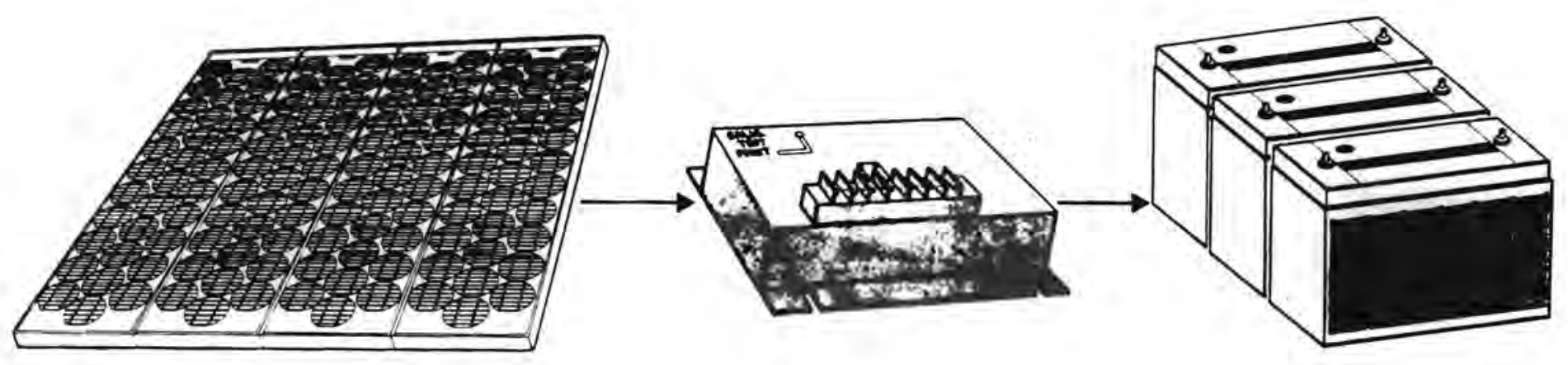

Purchasing a PV power package and using it for a variety of purposes is quite straightforward. The power packages work in any climate; however, the energy output is directly related to the amount of sunshine striking the panels. Seasonally, the systems can supply more power in the summer than in the winter in northern climates. As long as the electrical needs are adjustable and the user can tolerate reduced availabilities during periods of low insolation, the performance information supplied by the system manufacturer may be sufficient to size a satisfactory system.

These systems are intended to supply power where it is inconvenient or excessively expensive to make a connection to a utility grid. Utility lines to connect an individual user usually cost in excess of $\$ 10,000$ per mile and are often maintained at the purchaser's expense. With the current tax credit situation, it is possible to install a modest sized solar electric generator 
system and have no subsequent utility bills for a comparable investment. It is particularly attractive to install a modest system and add capacity each year while the tax credit lasts. The economic benefits of such a strategy is discussed in detail in section 6.4, and additional information on state tax credits is provided in Appendix I.

These power packages are rated in their ability to satisfy a given load measured in ampere hours (or watt hours) per day or week. Guidance in estimating your anticipated power needs is provided in section 4.1. Most of the currently available PV power packages are rated far below the average energy requirements for conventional residential applications. This is a consequence of the currently relatively high price of PV power compared to that available from utility grids. It makes more economic sense to make expenditures to minimize your electrical needs at first than to purchase huge PV arrays initially. Table 3.6 lists some DC power packages currently available.

Marine power systems are utilized in increasing numbers for critical applications other than the marine environment for which they were specifically designed due to their reputation for higher reliability. Due to the rather stiff competition for PV system sales in most instances the buyer can get what he's paying for. For applications where human life is at stake or liability of property loss exists, the purchase of premium quality components and professional design services are an absolute must.

\subsubsection{AC Power Packages}

With an adequately sized $A C$ power package one can operate conventional household appliances. Special AC power packages can be designed to connect to the electric utility supply lines so that excess power can be sold to the utility (with utility approval). These will become more common in the future, but at the present time they are retatively rare. The systems listed in this section are not intended to connect to conventional AC power grids.

An AC power package typically costs more than DC counterparts for three reasons: a) there is the added cost of an inverter, b) PV array sizes and battery storage must be increased $15 \%$ or more to make up for inverter losses, and c) typical AC appliances have been designed with little regard for 
TABLE 3.6. DC Power Package

\begin{tabular}{|c|c|c|c|c|}
\hline Application & Description & Supplier/Mfg. & $\begin{array}{l}\text { Typical } \\
\text { Average } \\
\text { Rating }\end{array}$ & $\begin{array}{l}\text { Approx. } \\
\text { List Price }\end{array}$ \\
\hline $\begin{array}{l}\text { Home Electric } \\
\text { Power System } \\
\text { with Modules } \\
\text { Mounted Out- } \\
\text { doors. }\end{array}$ & $\begin{array}{l}\text { 4-33 Watt PV } \\
\text { Modules (Model } \\
\text { ASI } 16-2000) \text {. } \\
3 \text { batteries } \\
105 A H, 12 \text { V each } \\
\text { (Delco 2000). } \\
\text { 1-Control Panel } \\
\text { 1-Pkg. Mounting } \\
\text { Hardware. }\end{array}$ & Arco Solar & 44AH/Day & $\$ 2500$ \\
\hline $\begin{array}{l}\text { Home Electric } \\
\text { Power Systems } \\
\text { with Modules } \\
\text { and Batteries } \\
\text { Outdoors. Con- } \\
\text { trols are in- } \\
\text { doors. } \\
\text { (Modei P-1-12) }\end{array}$ & $\begin{array}{l}\text { 1-33 Watt PV } \\
\text { Module } \\
\text { (Mode I ASI } 16 \\
-2000 \text { ). } \\
1 \text { Battery } 105 \\
\text { AH, 12V (Delco } \\
2000 \text { ). } \\
1 \text { Control } \\
\text { Pane } 1 \\
1 \text { Set Cables } \\
\text { \& Wires }\end{array}$ & $\begin{array}{l}\text { Solarwest } \\
\text { Electric }\end{array}$ & 7.5-13AH/Day & $\$ 900$ \\
\hline Mode 1 P-2-12 & $\begin{array}{l}\text { Same as above } \\
\text { but includes: } \\
2 \text { PV Modules } \\
2 \text { Batteries }\end{array}$ & $\begin{array}{l}\text { Solarwest } \\
\text { Electric }\end{array}$ & 15-27 AH/Day & $\$ 1550$ \\
\hline Mode 1 P-3-12 & $\begin{array}{l}\text { Same as above } \\
\text { but includes: } \\
3 \text { PV modules } \\
2 \text { batteries }\end{array}$ & $\begin{array}{l}\text { Solarwest } \\
\text { Electric }\end{array}$ & 22.5-40 AH/Day & $\$ 2200$ \\
\hline Model $\mathrm{H}-4-12$ & $\begin{array}{l}\text { Same as above } \\
\text { but includes } \\
4 \text { PV Modules } \\
3 \text { batteries }\end{array}$ & $\begin{array}{l}\text { Solarwest } \\
\text { Electric }\end{array}$ & 30-53 AH/Day & $\$ 2650$ \\
\hline $\begin{array}{l}\text { Industrial Grade } \\
\text { Systems for High } \\
\text { Reliability Uses. }\end{array}$ & $\begin{array}{l}185 \text { Standard } \\
\text { Solar Generators } \\
\text { for High Risk } \\
\text { Applications. }\end{array}$ & $\begin{array}{l}\text { Tideland } \\
\text { Signal Corp. }\end{array}$ & $\begin{array}{l}2 \text { AH/Day } \\
06 \text { V DC. } \\
55 \text { AH/Day } \\
\text { 0 } 6 \text { V DC } \\
\text { (other volt- } \\
\text { ages are } \\
\text { available) }\end{array}$ & $\begin{array}{l}\$ 533 \& \\
\text { up } \\
\$ 8745\end{array}$ \\
\hline
\end{tabular}




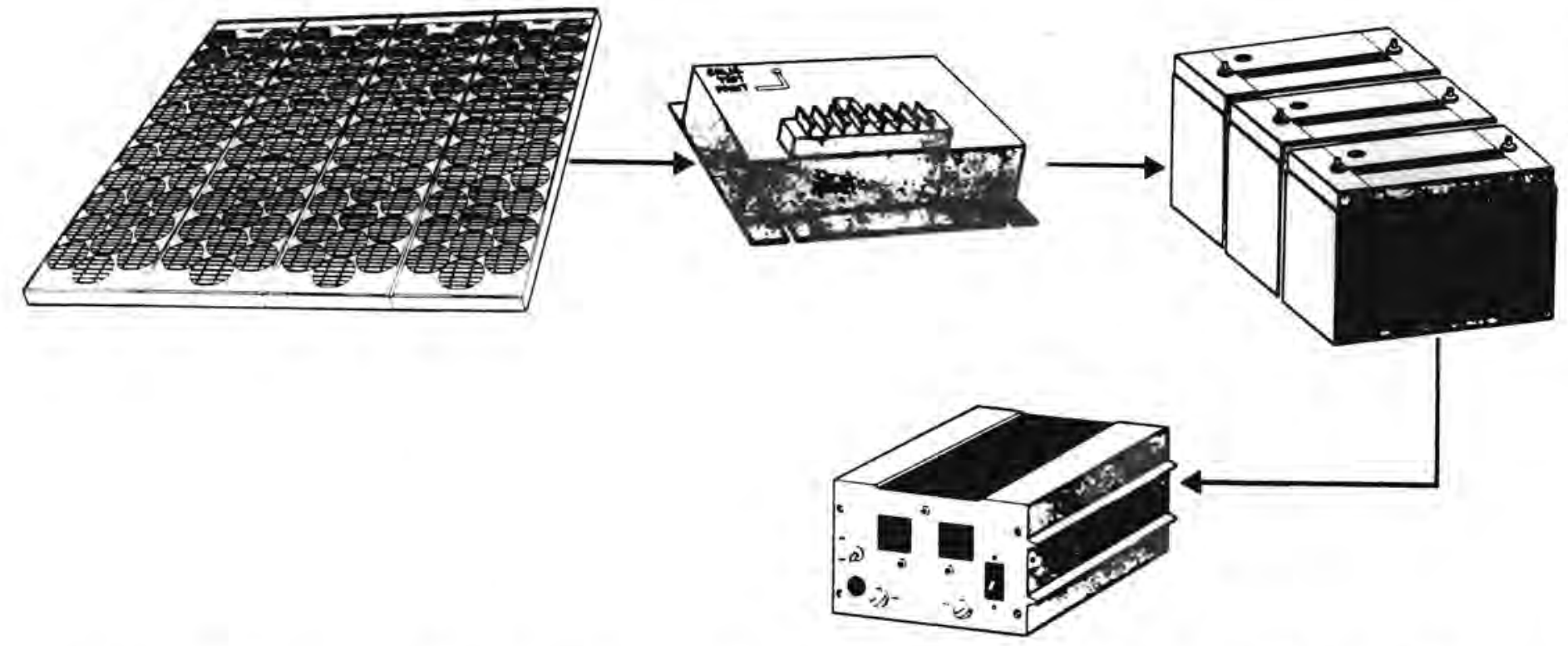

energy efficiency. For example, a typical incandescent AC powered light bulb requires 100 watts of power, whereas a highly efficient special DC powered fluorescent bulb requires about 25 watts to supply the same amount of light.

Although a 12 volt $D C$ system is the least costly and most energy efficient approach to energy independence, many desire to use AC appliances such as TV consoles, sophisticated stereo equipment, vacuum cleaners, hair dryers, etc. that he already owns. Since all of the AC power packages use the DC power supplied by the PV panels, it is possible and indeed may be advantageous, to investigate the possibility of installing a hybrid AC/DC system.

Ideally, a hybrid would supply DC power to everything except those appliances which require an $A C$ power supply. This would minimize inverter cost and power losses. Since inverters consume power even if no power is being drawn from them, it is important to place the inverters so they can be easily turned off or use remote or automatic switching mechanisms. If you are considering a hybrid system, make sure that the DC power is available at 12 volts. One of the systems listed in Table 3.7 stores electricity at 12 volts DC and has an inverter for supplying 1000 watts of AC load. This system could easily be used as a hybrid system by connecting a suitable fuse box to the battery. 


\section{TABLE 3.7. AC Power Packages}

\begin{tabular}{|c|c|c|c|c|}
\hline Manufacturer & Application & Description & Rating & Price \\
\hline ARCO SOLAR & $\begin{array}{l}\text { Remote residential- } \\
\text { comerical, indus- } \\
\text { trial }\end{array}$ & $\begin{array}{l}1 \text { energy block } \\
\text { consists of: } \\
1 \text { KW peak PV } \\
\text { modules, } \\
10 \text { Kwhr of } \\
\text { batteries, } \\
1 \text { set of } \\
\text { mounting struc- } \\
\text { tures, } \\
1 \text { ea. std. (NEMA) } \\
\text { control housing, } \\
1 \text { charge con- } \\
\text { troller, } \\
2 \text { sets fuses \& } \\
\text { circuit break- } \\
\text { ers, } \\
1 \text { set of voltage } \\
\text { surge arresters, } \\
1 \text { inverter (chosen } \\
\text { from the following): }\end{array}$ & $\begin{array}{l}\text { 2Kwhr/day } \\
\text { 4Kwhr/day } \\
\text { depending } \\
\text { on location. }\end{array}$ & \\
\hline & & $\begin{array}{l}25 \text { Series } \\
\text { (CAT \# 25-A-EBI) }\end{array}$ & $\begin{array}{l}2,500 \mathrm{~W} \\
\text { continuous }\end{array}$ & \\
\hline & & $\begin{array}{l}50 \text { Series } \\
\text { (CAT\# 50-A-EBI) }\end{array}$ & $\begin{array}{l}5,000 \mathrm{~W} \\
\text { continuous }\end{array}$ & \\
\hline & & $\begin{array}{l}100 \text { Series } \\
(C A T \# 100-A-E B I)\end{array}$ & $\begin{array}{l}10,000 \mathrm{~W} \\
\text { continuous }\end{array}$ & \\
\hline $\begin{array}{l}\text { SOLARWEST } \\
\text { Electr ic } \\
\text { Model AC12-12 }\end{array}$ & $\begin{array}{l}\text { Remote mobile homes } \\
\& \text { residences, } \\
\text { commercial }\end{array}$ & $\begin{array}{l}\text { 12-33 W } \\
\text { PV modules } \\
\quad \text { (Model ASI 16- } \\
2000 \text { ), } \\
8 \text { batteries } \\
\text { (Model Delco } \\
2000 \text { ), } \\
1 \text { charge controller } \\
\text { (Model UCC 12) } \\
1 \text { inverter } \\
\text { (Model Best 1000) }\end{array}$ & $\begin{array}{l}90-160 \mathrm{AH} / \\
\text { day } \\
\text { O12 V DC } \\
\text { (available } \\
\text { in this } \\
\text { rating but } \\
\text { fusing must } \\
\text { be added) or } \\
120 \vee A C 60 \\
\text { hz. }\end{array}$ & $\$ 8,400$ \\
\hline MODEL AC $16-24$ & & \multicolumn{2}{|l|}{$\begin{array}{l}\text { Same as above except, } \\
16 \text { PV modules } \\
12 \text { batteries } \\
1 \text { charge controller } \\
\text { (Model UCC } 24 \text { ) } \\
\text { i inverter } \\
\text { (Model Best } \\
2500 \mathrm{~W} \text { ) }\end{array}$} & $\$ 1.1,000$ \\
\hline MODEL AC $24-24$ & & $\begin{array}{l}\text { Same as above } \\
\text { except: } \\
24 \text { PV Modules } \\
16 \text { batteries }\end{array}$ & $\begin{array}{l}24 V D C \\
\text { not usable } \\
\text { for most } \\
\text { appliances } \\
\text { (use } A C \\
\text { only) at } \\
\text { rating of } \\
\text { not more } \\
\text { than } 2500 \mathrm{~W} \\
\text { for } 1840- \\
3265 \text { Whrs/ } \\
\text { day total. }\end{array}$ & $\$ 15,000$ \\
\hline
\end{tabular}




\subsection{HOME ELECTRIC SYSTEMS}

Home electric systems arre comprised of the components in the power packages 1 isted above as well as one or more matched appliances. These systems are an especially easy way to get started with PV. Only complete home electric systems are included here. Several firms offer appliances or appliance packages that leave out some key element. These are listed in Section 3.5. The starter systems currently available are listed in Table 3.8 .

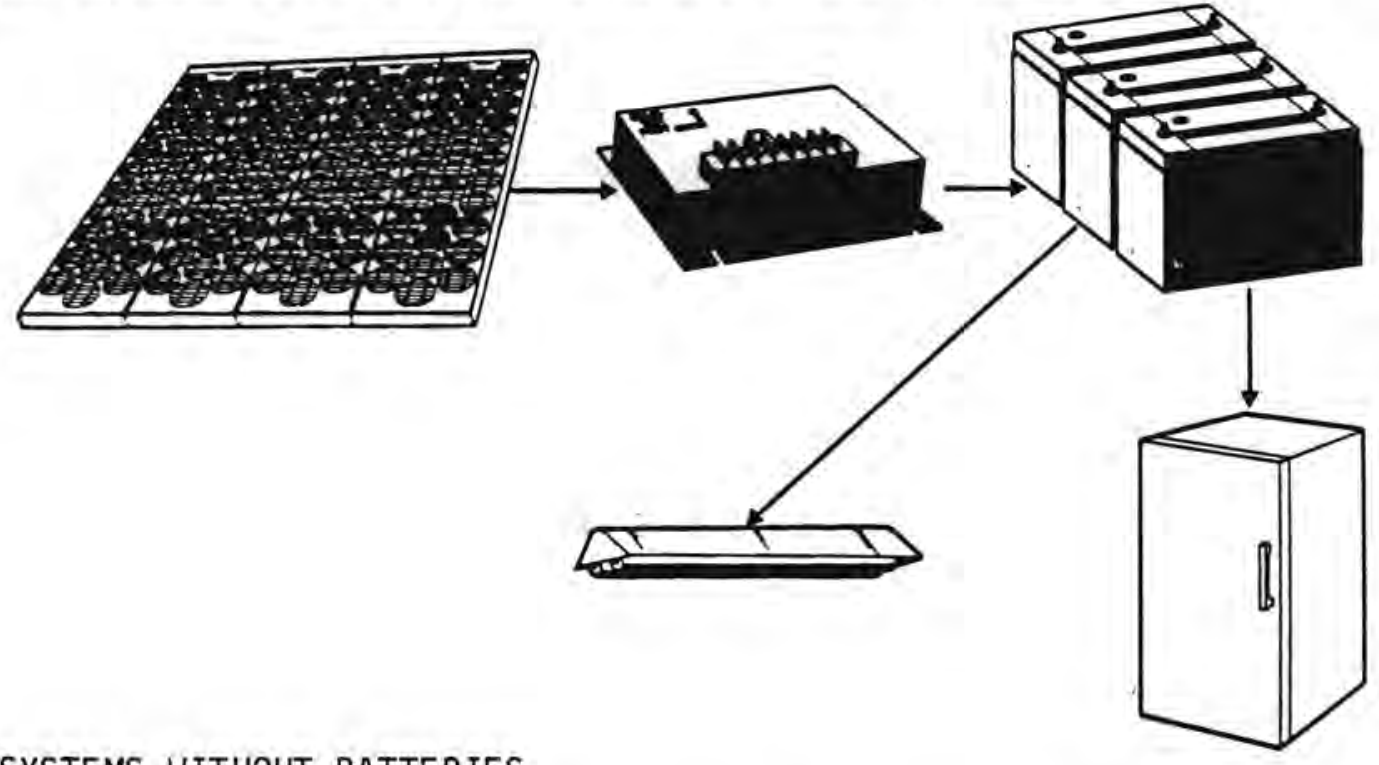

\subsection{SYSTEMS WITHOUT BATTERIES}

The following PV systems are complete except for batteries that can be purchased separately. Care should be taken in selecting batteries to assure system performance and reliability. Table 3.9 lists some systems without batteries.

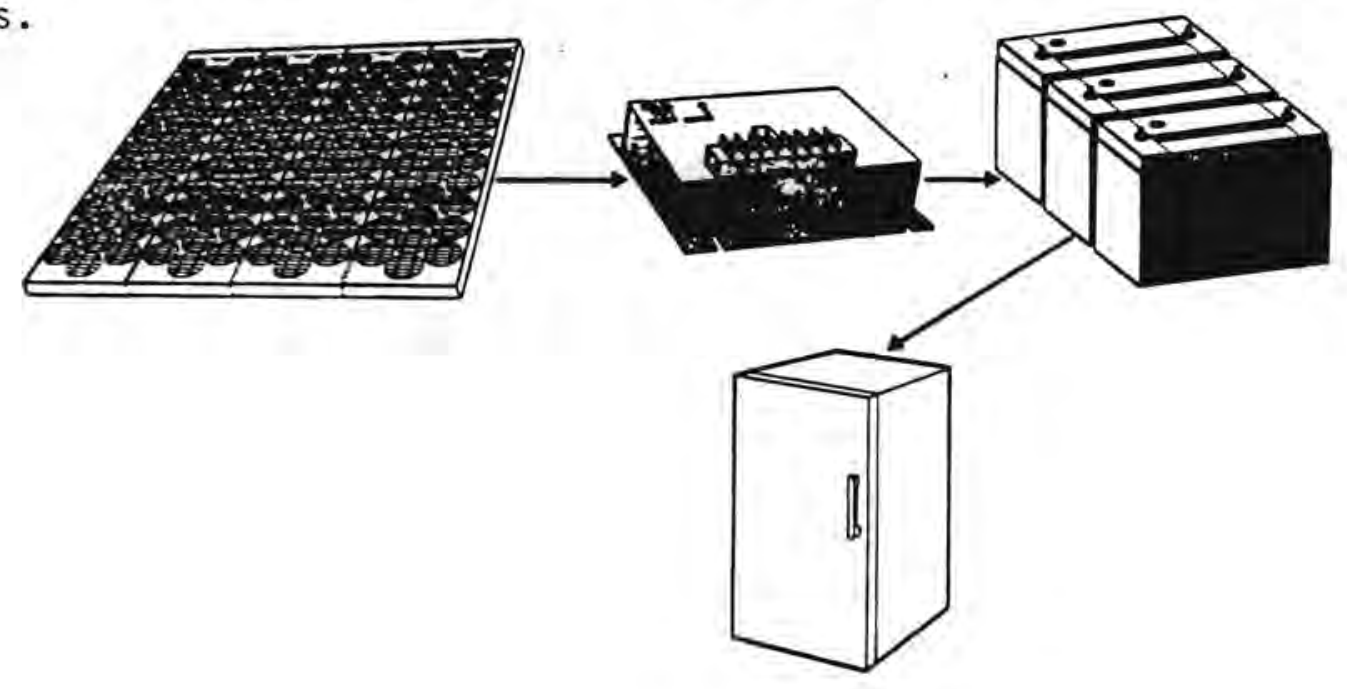




\section{TABLE 3.8. Home Electric Power Packages}

\begin{tabular}{|c|c|c|c|c|}
\hline $\begin{array}{l}\text { Supplier/Mfa. } \\
\text { Model \& No. }\end{array}$ & Appliance (s) & & Description & $\begin{array}{l}\text { Approx. } \\
\text { List } \\
\text { Price }\end{array}$ \\
\hline \multirow[t]{5}{*}{ ARCO SOLAR } & $\begin{array}{l}\text { Refrigerator } \\
\text { fluorescent } \\
\text { lights }\end{array}$ & & $\begin{array}{l}13.7 \mathrm{cu} \mathrm{ft} \\
\text { refrigerator } \\
\text { (Model WSP 1.2-6), }\end{array}$ & \\
\hline & & & $\begin{array}{l}220 \text { W } 1500 \text { lumen } \\
\text { fluorescent lights } \\
\text { (Model REC } 32-6 \text { ), }\end{array}$ & \\
\hline & & & $\begin{array}{l}433 \text { W PV Modules } \\
\text { (Model ASI 16-2000), }\end{array}$ & \\
\hline & & & $\begin{array}{l}3 \text { batteries } 105 \mathrm{AH} \\
\text { (Model Delco } 1150)\end{array}$ & \\
\hline & & $\cdot$ & $\begin{array}{l}1 \text { controller, hard- } \\
\text { ware \& wiring. }\end{array}$ & \\
\hline ARCO SOLAR & $\begin{array}{l}\text { Fluorescent } \\
\text { lights }\end{array}$ & & $\begin{array}{l}\text { Same as above w/o } \\
\text { refrigerator, add, } \\
140 \mathrm{~W} 3000 \text { lumen } \\
\text { fluorescent liaht }\end{array}$ & \\
\hline $\begin{array}{l}\text { Free Energy } \\
\text { Systems }\end{array}$ & $\begin{array}{l}\text { Fluorescent } \\
\text { lights }\end{array}$ & & $\begin{array}{l}1 \text { PV Module } \\
\text { (Model 129-SL) } \\
1 \text { battery } 28 \text { AH } \\
\text { gel cell, } \\
18 \mathrm{~W} 12 \mathrm{~V} \text { fluores- } \\
\text { cent light. }\end{array}$ & $\$ 499$ \\
\hline Motorola & Refrigerator & & $\begin{array}{l}\text { 1-4 cu. ft. } \\
\text { refrigerator } \\
4 \text { PV modules } \\
\text { 1 support structure } \\
3 \text { Delco } 2000 \\
\text { batteries } \\
2 \text { chg. controllers }\end{array}$ & NA \\
\hline SOLAREX & $\begin{array}{l}\text { Healthcare } \\
\text { refrigerator }\end{array}$ & & $\begin{array}{l}1 \text { refrigeratorl } \\
\text { freezer } \\
\text { w/controls \& } \\
\text { batteries, } \\
3 \text { PV Modules } \\
\text { (Powerline) }\end{array}$ & $\$ 5800$ \\
\hline \multirow[t]{2}{*}{$\begin{array}{l}\text { Solarwest } \\
\text { Electric }\end{array}$} & Fluorescent & light & $\begin{array}{l}115 \text { W } 8701 \mathrm{~m} \\
\text { fluorescent light } \\
\text { (Model REC 115) } \\
\text { 1 35 W PV module } \\
\text { (Model AST 16-2000) } \\
\text { 1 battery } 105 \text { AM } \\
\text { (Model Delco 2000) } \\
1 \text { controller }\end{array}$ & $\$ 924.50$ \\
\hline & Fluorescent & light & $\begin{array}{l}415 \mathrm{~W} 1050 \mathrm{~lm} \\
\text { fluorescent lights } \\
\text { (Model REC 1]0) } \\
333 \mathrm{~W} \text { PV modules } \\
\text { (Model ASI 16-2000) } \\
3 \text { batteries 105 Ah } \\
\text { (Model Delco 2000) } \\
\text { 1 controller }\end{array}$ & \\
\hline
\end{tabular}




\section{TABLE 3.9. Partial PV Systems}

\begin{tabular}{|c|c|c|c|c|}
\hline $\begin{array}{l}\text { Supplier/ } \\
\text { Mfg. } \\
\end{array}$ & Appliance & Description & $\begin{array}{l}\text { Parts } \\
\text { Missing }\end{array}$ & Price \\
\hline $\begin{array}{l}\text { Jim Cullen } \\
\text { Enterprises }\end{array}$ & $\begin{array}{l}\text { Fluorescent \& } \\
\text { incandescent } \\
\text { lighting }\end{array}$ & $\begin{array}{l}133 \mathrm{~W} \text { PV module } \\
122 \mathrm{~W} \text { fluorescent } \\
\text { lamp (table) conver- } \\
\text { sion kit. } \\
140 \mathrm{~W} \text { Double bullet } \\
\text { light incandescent }\end{array}$ & $\begin{array}{l}\text { Batteries } \\
- \\
t\end{array}$ & $\$ 500.00$ \\
\hline $\begin{array}{l}\text { MOTOROLA } \\
\text { (MSP 20001) }\end{array}$ & $\begin{array}{l}\text { Fluorescent } \\
\text { lights }\end{array}$ & $\begin{array}{l}\text { 1 } 20 \text { W peak } \\
\text { PV Module } \\
\text { (Model MSP 23A20), } \\
\text { 1 control module, } \\
120 \mathrm{~W} 810 \text { lumens } \\
\text { fluorescent light, } \\
1 \text { Wiring harness, } \\
1 \text { module support } \\
\text { hardware kit. }\end{array}$ & $\begin{array}{l}\text { Batteries } \\
60-80 \mathrm{AH} \\
\text { capacity }\end{array}$ & \\
\hline $\begin{array}{l}\text { MOTOROLA } \\
\text { (MSP T2OR20) }\end{array}$ & Television & $\begin{array}{l}120 \text { W peak } \\
\text { PV module } \\
\text { (Model MSP23A20), } \\
1 \text { control module, } \\
1 \text { wiring harness } \\
1 \text { module support } \\
\text { hardware kit }\end{array}$ & $\begin{array}{l}\text { Batteries } \\
60-80 \mathrm{AH}, \\
\text { capacity, } \\
\text { TV set } \\
12 \text { V DC }\end{array}$ & \\
\hline $\begin{array}{l}\text { Solarwest } \\
\text { Electric }\end{array}$ & $\begin{array}{l}\text { F luorescent } \\
\text { light }\end{array}$ & $\begin{array}{l}133 \mathrm{~W} \text { PV module } \\
1 \text { charae controller } \\
115 \mathrm{~W} 870 \text { lumens } \\
\text { fluorescent light }\end{array}$ & $\begin{array}{l}\text { Battery } \\
105 \mathrm{AH}\end{array}$ & $\$ 774.50$ \\
\hline $\begin{array}{l}\text { Standard } \\
\text { collectors } \\
\text { Inc. }\end{array}$ & Refrigerator & $\begin{array}{l}333 \mathrm{~W} P V \\
\text { modules, } \\
1 \text { charge con- } \\
\text { troller, } \\
1 \text { refrigerator } \\
5.1 \text { to } 7.1 \mathrm{cu} \mathrm{ft} .\end{array}$ & $\begin{array}{l}\text { Batteries } \\
85 \mathrm{AH} \\
\text { capacity }\end{array}$ & $\begin{array}{l}\$ 2300 \text { with } \\
\text { choice of } \\
\text { refrigera- } \\
\text { tor. }\end{array}$ \\
\hline $\begin{array}{l}\text { Western } \\
\text { Solar } \\
\text { Refrigeration }\end{array}$ & $\begin{array}{l}\text { Fluorescent } \\
\text { lights }\end{array}$ & $\begin{array}{l}140 \mathrm{~W} \text { pear } \mathrm{PV} \\
\text { array, } \\
120 \mathrm{~W} \text { fluores- } \\
\text { cent } 1 \text { ight }\end{array}$ & Batteries & $\$ 975.00$ \\
\hline \multirow[t]{2}{*}{$\begin{array}{l}\text { Western } \\
\text { Solar } \\
\text { Refrigeration }\end{array}$} & Refrigerator & $\begin{array}{l}\text { Solar Modules } \\
4 \text { cu.ft. refrig- } \\
\text { erators } \\
\text { Mtg. \& Wiring \& } \\
\text { Controls } \\
\text { Different number } \\
\text { of panels for } \\
\text { different climates. }\end{array}$ & Batteries & $\begin{array}{l}\$ 4,000 \\
\text { to } \$ 6,500\end{array}$ \\
\hline & $\begin{array}{l}\text { Fluorescent } \\
\text { lights }\end{array}$ & $\begin{array}{l}333 \text { W PV Modules } \\
1 \text { charge controller } \\
415 \mathrm{~W} 1050 \text { lumen } \\
\text { fluorescent lights }\end{array}$ & $\begin{array}{l}\text { Batteries } \\
105 \mathrm{AH}\end{array}$ & $\$ 1910.00$ \\
\hline
\end{tabular}




\subsection{SPECIAL IZED PV PRODUCTS}

Table 3.10 lists some specialized off-the-shelf products that use PV power sources. The list includes several novelty items, educational items, and other particularly useful PV applications.

\section{TABLE 3.10. Specialty PV Appliances}

\begin{tabular}{|c|c|c|c|c|}
\hline Item & Description & Specifications & $\begin{array}{l}\text { Mfg. } \\
\text { Supplier }\end{array}$ & $\begin{array}{l}\text { Approx. } \\
\text { Price }\end{array}$ \\
\hline $\begin{array}{l}\text { Parmak Electric } \\
\text { Fencer }\end{array}$ & $\begin{array}{l}\text { Completely self- } \\
\text { contained electric } \\
\text { fencer - in one } \\
\text { unit inc. gel } \\
\text { battery \& solar } \\
\text { module. }\end{array}$ & $\begin{array}{l}\text { Controls } 25 \text { Miles } \\
\text { of fence. Operates } \\
\text { up to } 21 \text { days in } \\
\text { total darkness. }\end{array}$ & $\begin{array}{l}\text { Parker-McCrory } \\
\text { Mfg. Co. }\end{array}$ & $\$ 75$ \\
\hline \multirow[t]{2}{*}{ AM Radios } & $\begin{array}{l}\text { Operates from dry } \\
\text { battery at night } \\
\text { from solar cells } \\
\text { during day time. }\end{array}$ & $\begin{array}{l}\text { AM band } 1.5 \mathrm{~V} \text {. } \\
\text { operating voltage, } \\
\text { dry battery used. }\end{array}$ & Solec Intern. & \multirow[t]{2}{*}{$\$ 40$} \\
\hline & $\begin{array}{l}\text { Operates from self- } \\
\text { contained recharge- } \\
\text { able battery } \\
\text { charged by self- } \\
\text { contained solar PV } \\
\text { module. }\end{array}$ & $\begin{array}{l}\text { AM band with } 3 \mathrm{~V} \\
\text { operation from } \\
2 \text { rechargeable } \\
\text { AA batteries }\end{array}$ & Solarex & \\
\hline Solar Flashlight & $\begin{array}{l}\text { Flashlight contains } \\
\text { rechargeable bat- } \\
\text { teries \& is sup- } \\
\text { plied with a plug } \\
\text { in solar PV charger }\end{array}$ & $\begin{array}{l}2.5 \mathrm{AH} \text { rechargeable } \\
\text { battery }\end{array}$ & Solarex & $\$ 30$ \\
\hline Solar Lantern & $\begin{array}{l}\text { Completely self- } \\
\text { contained Lantern } \\
\text { with rechargeable } \\
\text { battery }\end{array}$ & & Solarex & $\$ 25$ \\
\hline $\begin{array}{l}\text { Solar Bird \& } \\
\text { Game Feeders }\end{array}$ & $\begin{array}{l}\text { Automatic Bird \& } \\
\text { Game Feeders }\end{array}$ & & $\begin{array}{l}\text { Braden } \\
\text { Wire \& } \\
\text { Metal } \\
\text { Products }\end{array}$ & $\begin{array}{l}\$ 95 \\
\text { to } \\
\$ 335\end{array}$ \\
\hline $\begin{array}{l}\text { Petrous } \\
\text { "Solaris" } \\
\text { Calculator PV } \\
\text { powered }\end{array}$ & $\begin{array}{l}\text { Operates in most } \\
\text { any location where } \\
\text { there is normal } \\
\text { lighting level has } \\
\text { no batteries }\end{array}$ & Shell Oil Co. & Shell 0 il Co. & \multirow[t]{2}{*}{$\begin{array}{l}\$ 29 \\
\text { using } \\
\text { Shell } \\
0 i 7 \\
\text { credit } \\
\text { card } \\
\$ 29.95\end{array}$} \\
\hline $\begin{array}{l}\text { Teal Photon III } \\
\text { Solar calcula- } \\
\text { tor }\end{array}$ & $\begin{array}{l}\text { No batteries } \\
\text { needed }\end{array}$ & $\begin{array}{l}\text { LCD } 8 \text { digits } \\
\text { memory \& SQ RT }\end{array}$ & $\begin{array}{l}\text { Energy } \\
\text { House }\end{array}$ & \\
\hline
\end{tabular}




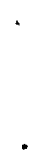




\subsection{BUILDING YOUR OWN SYSTEM}

The purpose of this chapter is to assist you in estimating your energy needs and to begin the design of a PV energy system to meet these needs. It is possible that after going through this procedure, you will discover that a. PV system is not the most suitable power source for your needs. Before making this decision, you should also read Chapter 7 which reports the actual experiences. However, until you have assessed your energy needs and the utility of a PV power supply, such a determination cannot be made. Consequently, we defer the question of the appropriateness of a PV system to Chapter 6 .

Many users are happy with PV Electric Systems (see Chapter 7) who selected their system without going through the procedures outlined in this chapter. They started with what they could afford. However, where requirements are demanding and inflexible, Chapter 4.0 must be used only as a preliminary estimating guide. The process here will be useful in helping you understand PV systems.

There are several tasks involved in designing your own PV system from scratch. We recommend a step by step approach consisting of the following six tasks:

Task 1. Evaluation of Energy Needs

Task 2. Select Appropriate Appliances

Task 3. Array Sizing and Selection

Task 4. Battery Sizing and Selection

Task 5. Select Power Conditioning Equipment

Task 6. Design Review

Although the process has several steps, the arithmetic is simple and the procedure should be straightforward for most readers. The best approach is to generate a rough estimate the first time through, and then refine the calculations on a second round.

Most PV manufacturers supply design guides for the asking that are tailored to their products or, alternatively, will assist serious inquirers in designing their systems with the use of sophisticated computer techniques. This 
service is extremely valuable and should be used after you have made anestimate using the process outlined here. The guidance offered here will allow you to understand the design process, will help you assess the appropriateness of a PV svstem, and can enhance your subsequent communications with suppliers.

In this discussion we do not emphasize applications such as warning beacons, navigation aids, etc. It's simply outside the scope of this presentation. There are companies in the business who understand these kinds of problems. They sell complete systems such as warning lights, etc. Two companies with experience in this field are Automatic Power (a Division of Pennwalt Corporation), and Tideland Signal Corporation. They assist customers with "risk and liability management". Properly designed PV systems are reported to be the most reliable power source in these applications, but designing these applications are not for the amateur.

\subsection{EVALUATION OF ENERGY NEEDS}

The key task involved in designing your own system is deciding how large a system you need or want. In practical terms, this will involve a decision about the size of your initial system, and ultimately how large a system you may need. Although most Americans use large amounts of electricity (particularly by world standards) very few have a notion of how much energy is used for particular applications. This is understandable since electricity, in this country, is about the cheapest in the world and is widely available. Given the rapid escalation of electricity rates, an analysis of your energy needs is useful whether you are planning a PV installation or not.

Another result of cheap electricity has been an apparent lack of concern regarding the energy efficiency of products. Increasing the energy efficiency of most appliances adds to their price; however, the value of the energy saved over the product lifetime usually exceeds this added cost. Consequently, when selecting new appliances for PV systems, energy efficient appliances are highly recommended. Refer to Section 4.2 for more information on appliance energy use.

The goal of this section is to help you estimate daily energy requirements in terms of watt hours/day. This requires an assessment of the following basic factors: 
0 the power requirements of applicances

0 the anticipated daily period of use for the applicances

0 the relative need or priority of appliance use

o the scheduling of appliance use

Subsequent sections in this chapter will help in the accomplishment of these tasks, and the example exercise at the end of this chapter will demonstrate how it is accomplished.

As you may recall from Chapter 2, a watt-hour is a unit of energy equivalent to the application of one watt of power for one hour. Since our goal is to determine the average number of watt hours required per day, we need to know the input power requirements (watts) of the appliances to be used and to estimate the average number of hours of daily use. The product of these two factors (derived by multiplication) is the estimate of watt-hours necessary per day.

We suggest that you use the format shown in Table 4.1 to tabulate your energy requirements and categorize the relative level of need. Before filling out this form in earnest we recommend that you finish reading this chapter so that you have some feeling of the system size and cost impacts of appliance selection and scheduling.

The power requirements of most appliances can usually be found in writing on the back of the appliance, in an owners handbook, or from a specifications sheet in terms of watts (see Table 4.2 for some typical power requirements). Some appliances are rated in terms of amps at a specified voltage and in this case the watts can be estimated by multiplying the figures. An important distinction to be made is whether the appliance requires $A C$ or $D C$ power. If $A C$ equipment is 1isted, you must add 15\% to the power requirement of the appliance to power the inverter which will be required. Enter the name and power requirements of the appliances you intend to use with a PV system in a form like Table 4.1 .

You must also list the $A C$ inverter as an appliance in order to include the "standby power" of this device. It will draw standby power when it is connected to the battery but no appliance is used. The $15 \%$ allowance takes care of 
TABLE 4.1. Estimate of PV System Size

\begin{tabular}{llccccc}
\multicolumn{1}{c}{} & \multicolumn{8}{c}{ Daily } & Energy & Requirement & & \\
Appliance & Power & Class & Class & Class & Percent & Storage \\
Req. & Req. & I & II & III & w/o Sun & Req. \\
\hline
\end{tabular}

DC Powered

$\mathrm{DC}$

AC Powered

AC TOTALS

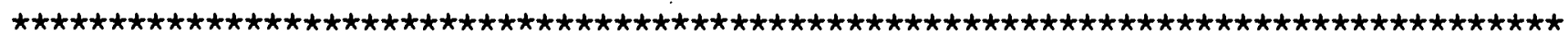

Power Conditioning

Peak Demands (watts): Inverter Capacity:

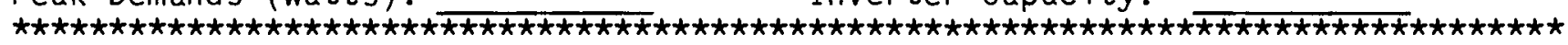
Battery Sizing

Storage Req.: watt-hours Depth of Charge Limit:

Number of Days Storage: Battery Capacity Req.:

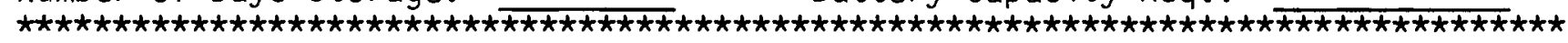
Array Sizing

Average Daily Load: Storage Req $X .2$ : Adjusted Total: watt-hours Sun hours per day: watt-hours Array Size (watts):

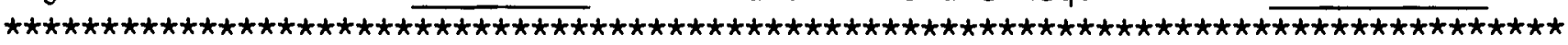


TABLE 4.2. Power Requirements for Common Appliances

High Efficiency $12 \mathrm{~V}$ DC Fluorescent

- 3000 lumens (approx. equal to $150 \mathrm{~W} \mathrm{Bulb)}$

$36 \mathrm{~W}$

- 2000 lumens (approx. equal to $100 \mathrm{~W} \mathrm{Bulb)}$

$24 W$

- 1500 lumens (approx. equal to $75 \mathrm{~W} \mathrm{Bu}$ lb)

$18 \mathrm{~W}$

Medium efficiency 12 V D.C. fluorescent

o 1700 lumens (slightly more than 75 W Bulb) 26 W

Standard light bulb (at 20 lumens/W)

o 2000 lumens (example) $100 \mathrm{~W}$

Ovens

o Microwave oven (120 V AC)

o Typical electric range (120 V AC)

$1.35 \mathrm{~kW}$

$10 \mathrm{~kW}$

Refrigerators

$07.1 \mathrm{cu} \mathrm{ft}, 12 \mathrm{~V} \mathrm{DC}$

$60 \mathrm{~W}$

o Standard $120 \mathrm{~V}$ AC

$500 \mathrm{~W}$

Stereo

- DC Car Type

$15 \mathrm{~W}$

o Home Stereo (AC)

$50 \mathrm{~W}$

Evaporative Coolers

- 5500 CFM

$455 \mathrm{~W}$

o 1200 CFM.

$70 \mathrm{~W}$

Sma11 Household Appliances

- Coffee perculator $115 \mathrm{~V}$ AC

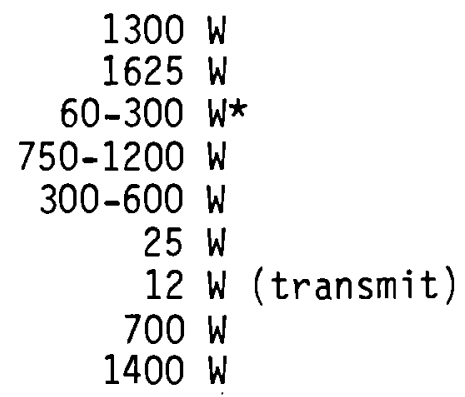

- Mr. Coffee $120 \mathrm{~V} \mathrm{AC}$

- Color TV

- Toaster

- Washing Machine

- Fan (smal1)

- C.B. Radio $12 \mathrm{~V}$

- Vacuum cleaner AC

- Hair dryer AC $1400 \mathrm{~W}$

ॠVaries considerably depending on size and model. 
inverter losses while it is supplying a normal load. Standby power can be considerable and can be avoided by using a "demand start" model or by turning the inverter on and off manually (see Section 4.5 .2 for a discussion).

The next step requires you to classify the power requirements and estimate the average daily hours of need. You can define the classes of power requirements however you wish, so long as you recognize that all uses are not equally important. The classifications we suggest are as follows:

Class I: Essential Uses not easily scheduled such as refrigeration

Class II: Priority Uses such as exhaust fans and appliances

Class III: Optional Uses such as power tools

The procedure is then to estimate the hours of appliance use in each of the classes, multiply by the power requirement and enter the figure under the appropriate use column.

In some instances entries will be more involved than it at first seems. Although refrigerators are used 24 hours/day, they typically draw current for only 6 to 12 hours/day depending upon the refrigerator and the usage. The energy efficiency labels required on new appliances by the Federal Trade Commission may be of help to complete this table. To assist you in estimating the energy needs of appliances or to see how yours compares with energy efficient ones, we refer you to Section 4.2 on appliance selection. Do not hesitate to contact appliance manufacturers before purchase.

There are some appliances that draw so little current that you don't need to worry about them or their period of use is so short as to be negligible in terms of average power consumption. Electric clocks and garbage disposals fall in these categories, respectively. However, it doesn't hurt to list them because you may need to account for them when sizing power conditioning equipment.

The timing of appliance use is important for it affects the size of battery storage and the capacity requirements of the power system. For each of the items in your appliance list, estimate what percentage of the time they will be used when the sun isn't shining (Table 4.3). You must use your discretion to determine what classes of use you include to calculate storage requirements, but we suggest the sum of classes I and II. Multiplying this percentage times 


\section{TABLE 4.3. Example PV System Entry}

\begin{tabular}{|c|c|c|c|c|c|c|}
\hline \multirow[b]{2}{*}{ Appliance } & \multicolumn{4}{|c|}{ Daily Fnerav Reauirement } & \multirow[b]{2}{*}{$\begin{array}{l}\text { Percent } \\
\text { w/o Sun }\end{array}$} & \multirow[b]{2}{*}{$\begin{array}{l}\text { Storage } \\
\text { Req. }\end{array}$} \\
\hline & $\begin{array}{l}\text { Power } \\
\text { Req. }\end{array}$ & $\begin{array}{c}\text { Class } \\
\text { I } \\
\end{array}$ & $\begin{array}{c}\text { C1ass } \\
\text { II }\end{array}$ & $\begin{array}{l}\text { Class } \\
\text { III }\end{array}$ & & \\
\hline AC Powered & & & & & & \\
\hline 3\&W Television & $50 *$ & 120 & 120 & & 50 & 120 \\
\hline
\end{tabular}

* Fifteen (15) percent is added for inverter power for AC appliances.

the daily use for each appliance and summing provides a baseline estimate for battery storage capacity. The smaller the number, the smaller the battery requirements and cost. Thus, some lifestyle changes which permit daytime use of the system may reduce overall system cost. This effect is discussed in more detail in Section 4.3.

For example, say you are considering the use of a $50 \mathrm{~W} \mathrm{AC} \mathrm{B \& W}$ television set. If you consider it essential to watch 2 hours of soap operas per day, and place a priority on watching an additional 2 hours in the evening, then your entry would appear as in Table 4.3.

Appliance scheduling will also affect the peak demands on the system and, therefore, its capacity rating. The peak demand on the system will occur when the maximum number of watts are drawn at one time. To determine this figure it is necessary to anticipate which combinations of simultaneous appliance use are necessary or desired. Typically, the lower the capacity rating, the lower the system costs. An additional factor which cannot be overlooked is that many AC appliances have higher power requirements when being started than during normal operation. Where $A C$ is used be sure to consider the "surge" power requirements when determining system capacity. More information on this issue is given in Section 4.5 .

If you've followed our suggested method, you have no doubt discovered that the arithmetic is much easier than deciding what to include. The technical aspects may be a bit confusing at first but really aren't hard. Making this table is something you must do yourself since each item is likely to be different or unique (some people like TV, others don't, etc.). It is advisable to 
be realistic, not idealistic here in order to be happy with the results later on. When you have completed this table, you will be more able to make several important decisions: a) Can you get along with DC alone?, b) If $A C$ is required, can small relatively inexpensive systems be used; for instance, to power a shaver or a radio? c) Do the AC needs outweigh the DC needs so much that a hybrid system will simply be a nuisance?, and d) Can you start with a smal1 system and work up in size over several years taking advantage of the tax breaks to their fullest?

\subsection{APPL IANCE SELECTION}

The selection of appliances to be powered by PV energy systems may entice you to exercise greater scrutiny than you're accustomed to. The task is not complex or confusing, but does require some additional investigation into the energy efficiency and power demands of the equipment. The information in this section should help you decide to become an informed "comparison shopper." In cases where you may not have the appliances you expect to use or you realize that what you do have requires an inordinate amount of power, be sure to consider the following guidelines in selecting new appliances.

There are four major factors for you to consider in addition to the others you commonly employ. These are:

- whether the appliance requires $A C$ or $D C$ current

0 the relative energy efficiency of the unit

0 the power demands of the unit when it is running

0 the percent of time it is actually running.

Clearly not all appliances are alike, even though they may appear identical and offer the same features. What you don't see is the amount of energy required to operate the equipment unless it is labeled with an appliance energy efficiency label. Often times you can compare the efficiency of equipment if you look in the owner's manual or on the back of the appliance for the power ratings.

First off, let's discuss the advantages of using DC powered appliances. These typically require a $12 \mathrm{~V}$ power supply or run off of batteries of various voltages. For application with PV power supplies (which by nature produce DC 
current) DC appliances may be preferred. In order to run an AC appliance from a PV power supply, an "inverter" must be employed which adds to the expense of the system and reduces the system efficiency. Some DC appliances may not be very efficient or durable, but the quantity and quality are improving rapidly. Some appliances are only available with $A C$ power requirements as yet and they must either be foregone or used in conjuction with an inverter. More information on inverters is presented in the next section.

Products for use with a DC power supply are becoming available in growing numbers, primarily due to demand for them by boat or recreational vehicle owners. Most cities now have distributors for such equipment which of ten have stock on display. We recommend that you look in the yellow pages under Recreational Vehicles to locate distributors in your area. Many have catalogs free for the asking which describe the variety of DC appliances available.

The energy efficiency of appliances be they AC or DC vary widely. When comparing efficiency you need to determine the energy consumed to accomplish a certain task. Often times this is made difficult by differences in the characteristics of the equipment, but if you can express energy use in common units the task is simplified. As mentioned previously, the energy efficiency labels required by the Federal Trade Comision on certain new appliances are invaluable indicators of the relative level of efficiency.

The tables which follow list a number of appliances specifically designed for 12 V DC application. They are generally quite energy efficient. We've deliberately left out $12 \mathrm{~V}$ light bulbs which are available from auto and hardware stores although they make perfect sense for intermittent short duty use. We've also not listed $115 \mathrm{~V} A C$ energy efficient appliances beginning to appear in most product lines in ordinary stoves. These appliances are typically much better than the older designs they replace but are not generally as well suited to application with small PV power supply systems as the DC appliances listed herein.

It is usually to your advantage to purchase the most efficient appliances available since they permit the power supply system costs to be minimized. Clearly a balance exists between added cost for the efficient appliance and the consequential savings in power system cost. In most all instances you will 
probably find after going through the sizing calculation that purchase of the most efficient appliance results in the lowest total cost. An illustrative example at the end of this section will bear this out.

Although light fixtures are commonly sold based upon the power (watts) they consume, buyers are really interested in the amount of light (1 umens) produced. A common home light bulb (incandescent type) will consume $100 \mathrm{~W}$ to provide 2000 $1 \mathrm{~m}$. This means you get $20 \mathrm{~mm} / \mathrm{W}$. A common fluorescent fixture rated at $20 \mathrm{~W}$ provides approximately $750 \mathrm{~lm}$ of 1 ight or about $40 \mathrm{~lm} / \mathrm{W}$. The common $120 \mathrm{VAC}$ fluorescent fixture is about twice as efficient as the incandescent bulb and furthermore, should outlast it. Very efficient DC fluorescent light fixtures available from many RV equipment centers can be twice again as efficient delivering about $80 \mathrm{~lm} / \mathrm{W}$. Those who are discomforted by the "flicker" of fluorescent lights will be glad to know that the high efficiency DC fixtures operate at a "flicker rate" many times as high as conventional bulbs which should be beyond human detection. Producers or distributors of some DC lighting fixtures claiming to produce in excess of $60 \mathrm{~lm} / \mathrm{W}$ are listed in Table 4.4 .

One of the lamps shown in Table 4.4 is a conversion for table 1 amps and is especially aesthetic in that it produces a warm tone to the room while giving light for working or reading.

Refrigerators are also available with widely differing efficiencies and power requirements. Some models have the capability of operating off of either DC or AC current as well as LPG. Although more expensive than the AC models currently available, they do not need inverters, therefore the DC models may be more cost effective. In addition the models which operate off of LPG also ensure that refrigerator temperatures will be maintained regardless of the availability of sunshine or the status of the batteries, allowing them to be shifted from class I to class II or III status (in filling out Table 4.1). Some of the DC refrigerators available are listed in Table 4.5. Additional refrigerators were included in Tables 3.8 and 3.9. Be sure to examine the peak power demands (while the compressor is running) as well as the normal amount of time the compressor must run to keep the refrigerator cold. 
TABLE 4.4. Efficient DC Light Fixtures

\begin{tabular}{|c|c|c|c|c|}
\hline Item & Description & Rating & Supplier Ap! & $\begin{array}{l}\text { roximate } \\
\text { rice } \\
\end{array}$ \\
\hline \multicolumn{5}{|c|}{$\begin{array}{l}\text { Fluorescent } \\
\text { Lighting }\end{array}$} \\
\hline $\begin{array}{l}20 \mathrm{~W} \\
\text { Fixture }\end{array}$ & $\begin{array}{l}25 " \text { unshaded tube and } \\
\text { fixture, } 83 \mathrm{~lm} / \mathrm{W}\end{array}$ & $\begin{array}{l}18 \mathrm{~W} \\
1500 \mathrm{~lm}\end{array}$ & $\begin{array}{l}\text { ARCO } \\
\text { Solar }\end{array}$ & \\
\hline $\begin{array}{l}40 \mathrm{~W} \\
\text { Fixture }\end{array}$ & $\begin{array}{l}49 " \text { unshaded tube and } \\
\text { fixture, } 83 \mathrm{~lm} / \mathrm{W}\end{array}$ & $\begin{array}{l}36 \mathrm{~W} \\
3000 \mathrm{~lm}\end{array}$ & $\begin{array}{l}\text { ARCO } \\
\text { Solar }\end{array}$ & \\
\hline Rev LII & $24.4 " \times 4.2 " \times 4.5 ", 61 \mathrm{~lm} / \mathrm{W}$ & $\begin{array}{l}19 \mathrm{~W} \\
1175 \mathrm{~lm}\end{array}$ & IOTA & $\$ 45$ \\
\hline $22 W$ & $\begin{array}{l}\text { Round } 91 / 2 " \text { Dia } \times 6 " \text { deep } \\
\text { table lamp conversion }\end{array}$ & $\begin{array}{l}15 \mathrm{~W} \\
1050 \mathrm{~lm}\end{array}$ & $\begin{array}{l}\text { Cul1en } \\
\text { Enterprises }\end{array}$ & $\$ 42$ \\
\hline $\operatorname{Rec} 110$ & $\begin{array}{l}\text { Round } 9.5 " \mathrm{Dia} \times 1.5 " \text { Deep } \\
\text { Approx. } 70 \mathrm{~lm} / \mathrm{W}\end{array}$ & $\begin{array}{l}15 \mathrm{~W} \\
1050 \mathrm{~lm}\end{array}$ & $\begin{array}{l}\text { Solarwest } \\
\text { Electric }\end{array}$ & $\$ 40$ \\
\hline Rec 116 & $\begin{array}{l}18 " \text { Long } \times 5.5^{\prime \prime} \text { Wide } \times 1.4 " \\
\text { Deep, } 72 \mathrm{~lm} / \mathrm{W}\end{array}$ & $\begin{array}{l}24 \mathrm{~W} \\
1740 \mathrm{~lm}\end{array}$ & $\begin{array}{l}\text { Solarwest } \\
\text { Electric }\end{array}$ & $\$ 30.50$ \\
\hline $\operatorname{Rec} 147$ & $\begin{array}{l}42 " \text { Long } \times 2.3^{\prime \prime} \text { Wide } x \\
1.3^{\prime \prime} \text { Deep, } 91 \mathrm{~m} / \mathrm{W}\end{array}$ & $\begin{array}{l}24 \mathrm{~W} \\
2200 \mathrm{~lm}\end{array}$ & $\begin{array}{l}\text { Solarwest } \\
\text { Electric }\end{array}$ & $\$ 30$ \\
\hline $\operatorname{Rec} 151$ & $\begin{array}{l}\text { 24" Long } \times 2.75 " \text { Wide } x \\
2.4 " \text { Deep, } 70 \mathrm{~lm} / \mathrm{W}\end{array}$ & $\begin{array}{l}18 \mathrm{~W} \\
1260 \mathrm{~lm}\end{array}$ & $\begin{array}{l}\text { Solarwest } \\
\text { Electric }\end{array}$ & $\$ 50$ \\
\hline Rec 153 & $\begin{array}{l}\text { 48" Long } \times 2.75 " \text { Wide } x \\
2.4 " \text { Deep, } 87 \mathrm{~lm} / \mathrm{W}\end{array}$ & $\begin{array}{l}36 \mathrm{~W} \\
3150 \mathrm{~lm}\end{array}$ & $\begin{array}{l}\text { Solarwest } \\
\text { Electric }\end{array}$ & $\$ 65$ \\
\hline \multicolumn{5}{|c|}{$\begin{array}{l}\text { Fluorescent } \\
\text { Thinlite }\end{array}$} \\
\hline$\# 116$ & $\begin{array}{l}\text { 18" Long } \times 5.5 " \text { Wide } \times 1- \\
3 / 8^{\prime \prime} \text { Deep, } 681 \mathrm{~m} / \mathrm{W}\end{array}$ & $\begin{array}{l}26 \mathrm{~W} \\
1760 \mathrm{Im}\end{array}$ & $\begin{array}{l}\text { Free Energy, } \\
\text { Energy House }\end{array}$ & $\$ 23.33$. \\
\hline$\# 126$ & $\begin{array}{l}21 " \text { Long } \times 5.5 " \text { Wide } \times 1 " \\
\text { Deep, } 661 \mathrm{~m} / \mathrm{w}\end{array}$ & $\begin{array}{l}26 \mathrm{~W} \\
1720 \mathrm{~lm}\end{array}$ & $\begin{array}{l}\text { Free Energy, } \\
\text { Energy House }\end{array}$ & \\
\hline
\end{tabular}


TABLE 4.5. DC Powered Refrigerators

\begin{tabular}{|c|c|c|c|c|c|c|c|}
\hline Company & Model & $\begin{array}{l}\text { size } \\
\left(\mathrm{ft}^{3}\right)\end{array}$ & $\begin{array}{l}\text { Top (T) } \\
\text { or Front } \\
\text { (F) Opening }\end{array}$ & $\begin{array}{c}\text { Power } \\
\text { Consumption } \\
\text { (watts) } \\
\end{array}$ & $\begin{array}{c}\text { Energy } \\
\text { Consumption/Day }\end{array}$ & $\begin{array}{l}\text { Price } \\
\text { \$/Unit }\end{array}$ & Comments \\
\hline Norcold & DC 254 & $\begin{array}{l}4.2 \text { (exter- } \\
\text { ior Vol.) }\end{array}$ & F & 54 & 650 & $\$ 315$ & $\begin{array}{l}\text { Most of Norcold's } \\
\text { wide range of refri- } \\
\text { gerators run on } A C \\
\text { or } D C \text {. Here we've } \\
\text { only included their } \\
\text { purely } D C \text { ref. }\end{array}$ \\
\hline Norcold & DC 230 & $\begin{array}{l}3.3 \text { (exter- } \\
\text { ior Vol.) }\end{array}$ & $F$ & 54 & 650 & $\$ 285$ & \\
\hline $\begin{array}{l}\text { Western } \\
\text { Solar } \\
\text { Refrigeration }\end{array}$ & WSR 12-1 & 4.1 & T & 72 & $250-288$ & $\$ 1300$ & Refrigerator/freezer \\
\hline $\begin{array}{l}\text { Solarwest } \\
\text { Electric \& }\end{array}$ & $\begin{array}{l}\text { ARCO Solar } \\
\text { WSP-12-6 }\end{array}$ & 3.7 & T & 66 & 264 & $\$ 1500$ & \\
\hline ARCO Solar & $\begin{array}{l}\text { Instamatic } \\
\text { IE-12V }\end{array}$ & 2.8 & $\mathrm{~F}$ & 36 & 432 & $\$ 350$ & \\
\hline $\begin{array}{l}\text { Standard } \\
\text { Solar } \\
\text { Collectors }\end{array}$ & $\begin{array}{l}J 1080-2 M \\
J 1080-7 \\
J 1080-5 \\
J 1080\end{array}$ & $\begin{array}{l}5.2 \\
5.7 \\
5.25 \\
7.1\end{array}$ & $\begin{array}{l}F \\
F \\
T \\
T\end{array}$ & $\begin{array}{l}60 \\
60 \\
60 \\
60\end{array}$ & $\begin{array}{l}172-690 \\
172-690 \\
172-690 \\
172-690\end{array}$ & $\begin{array}{l}\$ 550-600 \\
\$ 560-610 \\
\$ 575-620 \\
\text { NA }\end{array}$ & \\
\hline $\begin{array}{l}\text { Jim Cullen } \\
\text { Enterprises, } \\
\text { Inc. }\end{array}$ & Cold Star Cs-4 & 3.9 & $\mathrm{~F}$ & 90 & 2160 & $\$ 475$ & $\begin{array}{l}3 \text { way system } 110 \vee \\
A C, 12 \vee D C, L P \text { Gas. } \\
\text { Carries a wide range } \\
\text { of refrigerators. }\end{array}$ \\
\hline
\end{tabular}

* Based on published data, different ambient conditions may apply.

An illustration of the impact of using a conservation approach is provided by the following example where two systems are compared. The example involves: both a) the use of energy efficient products and b) life style adjustments to minimize energy needs. It is assumed that space and water heating, cooking, and air conditioning are provided by nonelectric methods. The remaining electrical loads are estimated in Table 4.6 for standard and energy conserving appli ance use.

It is apparent that adjustments in lifestyle and use of efficient appliances can reduce the energy requirements dramatically allowing one to begin using PV systems in a modest way. The difference is even more impressive when the resultant costs of a PV energy system are compared to fulfill the needs.

In this example the $A C$ power package, $A C$ 12-12, listed in Table 3.7 would handle the 609 Whr with a 50\% reserve margin at a system cost of about 
TABLE 4.6. Comparison of Standard and Energy Conserving App $1 i$ ance Use

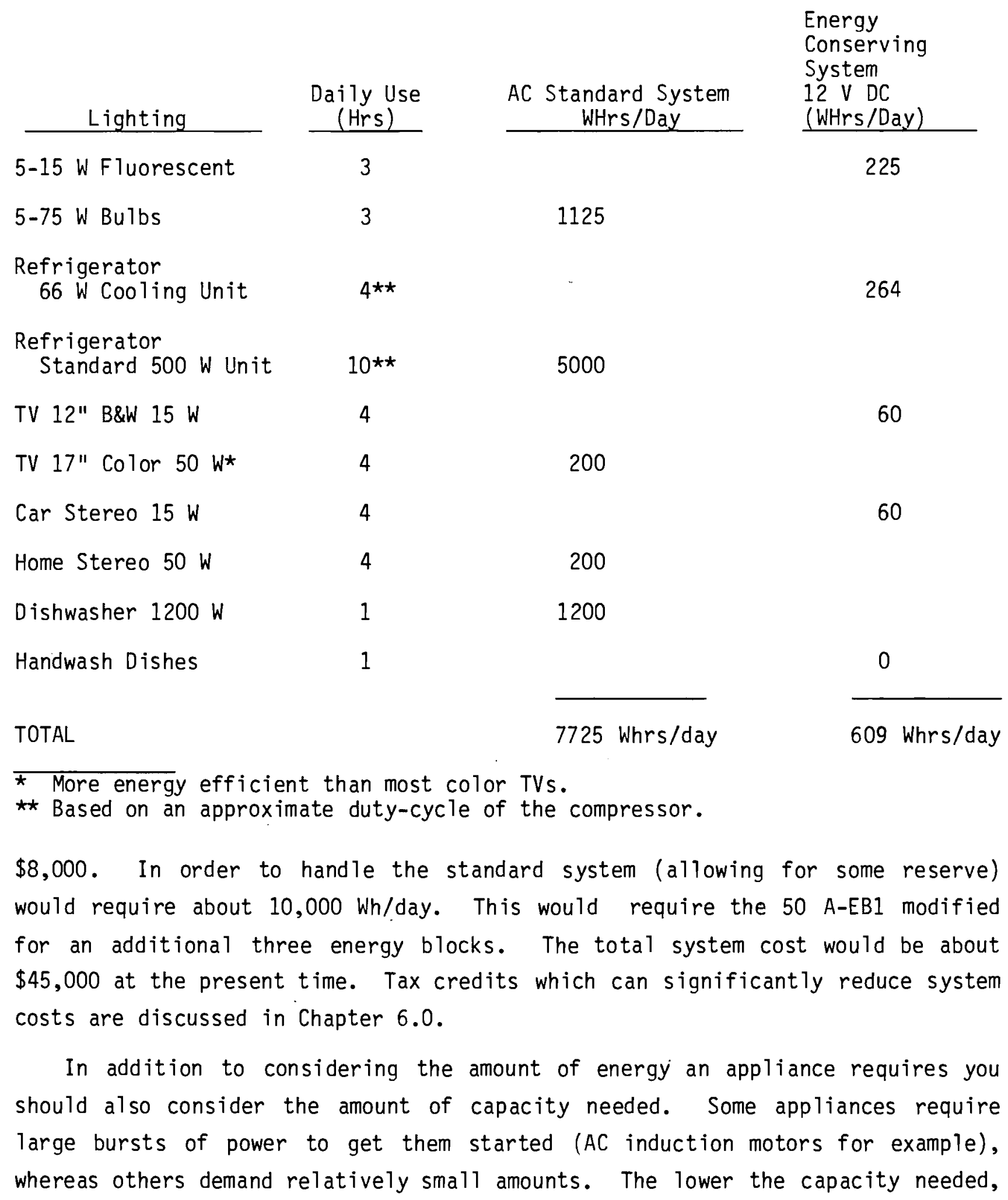


usually the less expensive the system is to supply it. When comparing two appliances with otherwise similar features, choose the one with the lowest amperage requirement.

\subsection{ARRAY SIZING AND SELECTION}

The sizing of a PV array will depend upon the average daily load on the system, the amount of system inefficiency losses, the average amount of sunlight available, and the back-up power supply available. Very sophisticated computer modeling techniques have been developed to calculate array and storage system size, and indeed form the basis for the manual technique described here. Some manufacturers and installers will use these computer tools to assist you in refining your design.

The first step is to determine a grand total for your energy needs from Table 4.1 by adding the $A C$ and DC power requirements. Next add $20 \%$ of the storage requirement total to account for energy losses in the battery charge/ discharge cycle. Since you've already accounted for the inverter losses if any, this figure represents the adjusted average daily energy your PV array must supply if no back up is to be used.

The next step is to consult Figures 4.1 and 4.2 to determine the effective (or equivalent) sun hours available in your climatic area. If the system is designed for year round use, and your wintertime loads must be met with the PV array alone, the array should probably be sized according to Figure 4.2 which provides an estimate of the lowest average seasonal levels of sunlight. In order to calculate array capacity divide the adjusted average daily energy requirement calculated above by the sun hours. This is your array wattage requirement.

\section{$\frac{\text { Total Average Daily Energy Requirements }}{\text { Number of Sun Hours }}=$ Array Wattage Requirement}

One common myth is that the sun does not shine in Seattle in the winter. It is true that the sunlight is filtered through a dense cloud layer for a number of days per year, but sufficient sunlight is available to produce PV electricity. Only above the Arctic Circle does the sun actually go away in the 


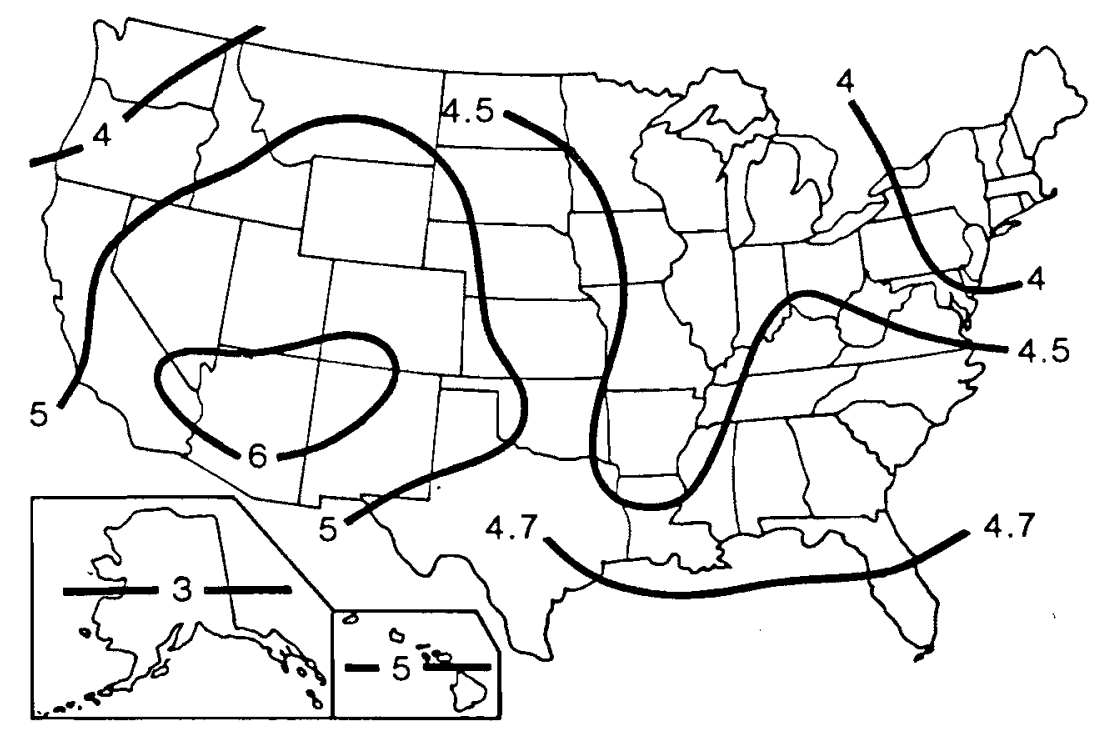

FIGURE 4.1. Peak Sun Hours Per Day - Yearly Average

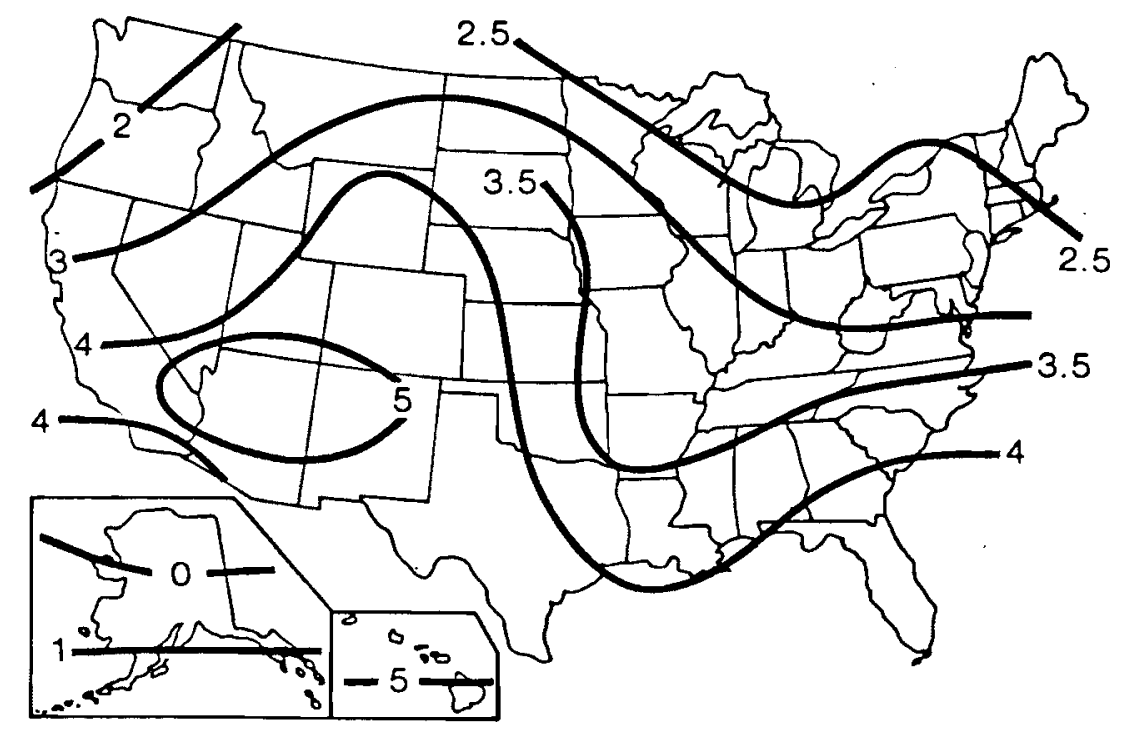

FIGURE 4.2. Peak Sun Hours Per Day - 4 Week Average 12/7-1/4

Courtesy of Solarex Corporation. 
winter. No alternative to a backup charger or large battery banks exists for wintertime use of PV systems above the Arctic Circle. A high quality backup generator, 4.5 CM $21 \mathrm{RV}$, made by Kohler produces $4,500 \mathrm{~W}$ and has numerous "quieting" features selling for about $\$ 1,800$.

In order to determine the number of modules required divide the array wattage by the wattage of the module. The resultant figure should then be rounder up to the next whole number. This is your est imated module requirement.

\section{$\frac{\text { Array Wattage Requirement }}{\text { Module Wattage }}=$ Number of Modules Required}

Check module requirements with the manufacturer or distributor, or use the NASA Report listed in the reference section.

Table 4.7 is a list of firms who either manufacture or distribute PV modules in the U.S., with an example of the type of PV module available. Most companies manufacture a variety of module sizes, however, space limitations prevent us from presenting a 11 of them.

The PV cells are a higher cost portion of modules and arrays as well as the entire PV system (excluding storage). Therefore, it will pay to use ingenuity to derive as much power as possible from each PV cell to reduce the number of cells needed. There are two things that can be done to increase the output of a given cell: a) point it directly at the sun, and b) use a lens or mirror to reflect more light onto the cell.

Devices to direct the array (containing the cells) directly at the sun can effectively lengthen the day so that nearly full output of the array can be obtained from sunup to sundown. This can approximately double the output of energy from a cell under good conditions compared to the usual approach of leaving the array'fixed in some compromise position. When lenses or mirrors are used to concentrate the suns rays, the amount of electricity from a cell can be increased nearly directly with the increase in light intensity. Special provisions must be made to carry away the heat and conduct the greater amount of electricity being produced when high concentrations of sunlight are used.

Concentrator methods are under development to reduce costs. When using concentrating collectors, it becomes essential to also track the sun (keep the 


\section{TABLE 4.7. Example Off-the-shelf PV Modules}

\begin{tabular}{|c|c|c|c|c|c|c|}
\hline Company & $\begin{array}{l}\text { Module } \\
\text { Name }\end{array}$ & $\begin{array}{l}\text { Peak } \\
\text { Power } \\
\text { (Watts) }\end{array}$ & $\begin{array}{l}\text { Voltage } \\
\text { (Volts) }\end{array}$ & $\begin{array}{l}\text { Module } \\
\text { Size }\end{array}$ & Application & $\begin{array}{l}\text { Approx. List } \\
\text { Price }\end{array}$ \\
\hline ARCO Solar & $\begin{array}{l}\text { ASI 16- } \\
2000\end{array}$ & 35 & 20 & $\begin{array}{l}47.9 " \times 11.9 " \\
\times 1.5^{\prime \prime}\end{array}$ & General & $\$ 450 /$ Module \\
\hline $\begin{array}{l}\text { ALPHA Energy } \\
\text { Systems }\end{array}$ & & & & & $\begin{array}{l}\text { Module } \\
\text { Distributor/ } \\
\text { Dealer }\end{array}$ & \\
\hline $\begin{array}{l}\text { Applied } \\
\text { Solar } \\
\text { Energy }\end{array}$ & $60-3053$ & 80 & 32 & $\begin{array}{l}1.54 " \times 27.38 " \\
\times 47.24\end{array}$ & General & \\
\hline $\begin{array}{l}\text { Automat ic } \\
\text { Power }\end{array}$ & SP620 & 4.3 & 7.2 & NA & & NA \\
\hline $\begin{array}{l}\text { Jim Cullen } \\
\text { Enterprises }\end{array}$ & & & & & $\begin{array}{l}\text { Module } \\
\text { Distributor' } \\
\text { Dealer }\end{array}$ & $\$ 450 /$ module \\
\hline $\begin{array}{l}\text { Energy } \\
\text { House }\end{array}$ & & & & & $\begin{array}{l}\text { Module } \\
\text { Distributor/ } \\
\text { Dealer }\end{array}$ & \\
\hline $\begin{array}{l}\text { Free Energy } \\
\text { Systems }\end{array}$ & $129 \mathrm{SQ}$ & 10 & 18 & $\begin{array}{l}15.25^{11} \times 15.25 \\
\times 0.5^{\prime \prime}\end{array}$ & $\begin{array}{l}\text { Marine } \\
\text { Applications }\end{array}$ & $\$ 399 /$ Module \\
\hline $\begin{array}{l}\text { Glass Energy } \\
\text { Electronics }\end{array}$ & & & & & $\begin{array}{l}\text { Module } \\
\text { Distributor/ } \\
\text { Dealer }\end{array}$ & \\
\hline $\begin{array}{l}\text { International } \\
\text { Rectifier }\end{array}$ & & & & & $\begin{array}{l}\text { Custom } \\
\text { Modules }\end{array}$ & \\
\hline Mobil/Tyco & Ra40 & 40 & $10-21$ & $42^{\prime \prime} \times 17^{\prime \prime} \times 2 "$ & General & $\$ 1000 /$ Module \\
\hline Motorola & MSP 43E40 & 40 & 19.5 & $14 " \times 48 " \times 1.5 "$ & General & \\
\hline $\begin{array}{l}\text { Photon } \\
\text { Power }\end{array}$ & $\begin{array}{l}\text { Photon } \\
\text { Power }\end{array}$ & $80-100$ & & $4.5^{\prime} \times 8.5^{\prime}$ & $\begin{array}{l}\text { An 8-Panel } \\
\text { Module }\end{array}$ & $\$ 5-\$ 12 / W p$ \\
\hline Photowatt & MB3310 & 18.6 & 20.5 & $11.3^{\prime \prime} \times 36^{11} \times .875 "$ & Genera 1 & $\$ 304 /$ Module \\
\hline $\begin{array}{l}\text { Silicon } \\
\text { Sensors }\end{array}$ & $\begin{array}{l}\text { SPP 3300- } \\
12\end{array}$ & 33 & & $30 " \times 24 " \times 2 "$ & General & $\$ 625$ Module \\
\hline $\begin{array}{l}\text { Solar } \\
\text { Power } \\
\text { Corp. }\end{array}$ & $612-361$ & 33.5 & 16.5 & $44 " \times 17 " \times 2.25 "$ & General & \\
\hline $\begin{array}{l}\text { Solar Usage } \\
\text { Now }\end{array}$ & & & & & $\begin{array}{l}\text { Module } \\
\text { Distributor/ } \\
\text { Dealer }\end{array}$ & \\
\hline Solarex & 4330 & 35 & 20 & $26 " \times 261 / 2 "$ & General & $\$ 1130 /$ Module \\
\hline $\begin{array}{l}\text { Solec } \\
\text { Intern. }\end{array}$ & $5-4134$ & 23.4 & 18.5 & $37 " \times 16^{\prime \prime} \times 1 "$ & Genera 1 & $\$ 600 /$ Module \\
\hline $\begin{array}{l}\text { Solenergy } \\
\text { Corp. }\end{array}$ & SG1294-G & 33 & $\begin{array}{l}12 \\
\text { (NOM) }\end{array}$ & $\begin{array}{l}23.6 " \times 30.2^{\prime \prime} \\
\times 1.75^{\prime \prime}\end{array}$ & General & \\
\hline Solanwest & $\begin{array}{l}\text { ASI 16- } \\
2000\end{array}$ & 35 & 20 & $48 " \times 12 " \times 1.5 "$ & $\begin{array}{l}\text { Module } \\
\text { Distributor/ } \\
\text { Dealer }\end{array}$ & $\$ 450 /$ Module \\
\hline Sollos & P264 & $10-12$ & 12.75 & $18^{\prime \prime} \times 18^{\prime \prime} \times .5^{\prime \prime}$ & Irrigation & NA \\
\hline $\begin{array}{l}\text { SPIRE } \\
\text { Corp. }\end{array}$ & $\begin{array}{l}\text { Hi Perfor- } \\
\text { mance }\end{array}$ & -60 & 22 & $47 " \times 16 " \times 2.4 "$ & General & . \\
\hline $\begin{array}{l}\text { Tidel and } \\
\text { Signal }\end{array}$ & $M G-300 / 12$ & 3.8 & 13.4 & $10 " \times 10 "$ & $\begin{array}{l}\text { Naviga- } \\
\text { tional Aids }\end{array}$ & $\$ 242$ Module \\
\hline $\begin{array}{l}\text { United } \\
\text { Energy } \\
\text { Corp. }\end{array}$ & 1212 & 20.3 & 14.5 & $25 " \times 15 " \times 3 / 8 "$ & General & $\$ 400 /$ Module \\
\hline $\begin{array}{l}\text { Applied } \\
\text { Solar } \\
\text { Energy }\end{array}$ & $60-3053$ & 80 & 32 & $\begin{array}{l}1.54 " \times 27.38 " \\
\times 47.24\end{array}$ & General & NA \\
\hline
\end{tabular}


lens between the sun and the cell). A passive solar tracking device is available from Zomeworks. Several manufacturers have supplied information about concentrators summarized in Table 4.8.

Standard modules gather sunlight on hazy or cloudy days. It is quite surprising to observe a 2 amp panel producing a little less than a quarter ampere in Seattle, Washington, with complete cloud cover. Ordinarily concentration systems do not work as well under cloudy or hazy conditions. Most concentrator systems are presently being recommended by suppliers only for larger installations.

There are several things to consider in purchasing a concentrator array:

- Reliability of tracking apparatus

- Maintenance and service requirements of concentrators and tracking apparatus

- Performance in the specific climate conditions encountered

TABLE 4.8. Concentrators and Arrays

Mode 1/

Supplier

Automatic Power

"Solar Power

Concentrators"

Solarex

C 250 Array

Acurex

$3001-P$

AAI

$\mathrm{PV} /$ thermal

Linear Concentrating

Acurex

Solar PV

Concentrator
Description

Removeable aluminum mirrors bolt to SP 320 or SP 620 automatic power modules.

6 panels produce $250 \mathrm{~W}$ peak output flat mirrors attach above \& below modules.

Parabolic through actively cooled concentrating array with single axis tracking, can thus supply hot water in addition to electricity

Linear mirrors focus sun on a line of PV concentrator cells providing both electricity and hot water at $190^{\circ} \mathrm{F}$ single axis tracking

Tracking array (2 axis) of sealed beam headlight type PV concentrators
Approximate Concentration Ratio

About 1.5 without tracking or adjustment

About 1.5 without tracking or adjustment

40

40

100 
- Appearance factors (a pedestal tracking array looks unusual in some neighborhoods)

- Any unusual environmental conditions.

If you have any questions regarding the performance of your module(s), you can send them to DSET Laboratories, Inc. for testing and other assistance.

\subsection{BATTERY SIZING AND SELECTION}

This section provides a method by which you can estimate the size of battery storage needed and provides some guidance in the selection of batteries. The reader is cautioned that battery technology is quite complex, and the variety of batteries available is great. Consequently, investing time in the study and selection of batteries is very worthwhile.

We cannot possibly present and explain in this directory all battery issues and products available, but we will attempt to raise issues of paramount importance and offer some guidance in the design and selection of electrical storage batteries. If you've completed Table 4.1, you are well on your way to determining the battery storage requirements.

\subsubsection{Sizing Battery Storage}

By estimating the percent of time that appliances will be used during nonsunlight hours, and multiplying this figure times the average watt-hours used per day, you have determined the amount of energy which typically needs to be removed from battery storage each night for that appliance. By adding up this figure for all the appliances we derive the total amount of energy needed to be removed from the battery storage system on a typical daily cycle.

The life, and consequently the cost effectiveness, of batteries is based upon: a) the number of times the battery is discharged or "cycled", b) the percentage of the total battery charge (depth of discharge) which is removed during the cycle and, c) the quality of maintenance. Each type of battery responds differently. So the question which needs to be answered is "What depth of discharge is best to maximize battery life and minimize storage size." Given the variety of batteries available whose characteristics differ and the widely divergent loads placed upon them, a simple universal answer is not 
available. The question is best resolved by discussions with battery manufacturers or suppliers.

In "typical" PV applications, ideal practice is to specify good quality batteries experiencing a 10\% average depth of discharge which will last approximately 5 years. Using fewer batteries and increasing the depth of discharge so as to provide the same amount of energy daily, may shorten battery life and reliability but may still be cost effective. On the other hand using more batteries and further reducing the average discharge depth increases the cost of the storage system to a point which may not be recovered by anticipated extensions in battery life.

In actual practice, deep cycle batteries are being discharged more than $10 \%$ on a daily basis, with fairly good life which saves considerabley on system first costs.

The actual depth of discharge in a PV system can vary from 0 to as much as 90\% of capacity if necessary if the battery is designed for this, since an occasional deep discharge isn't too harmful. However, one is faced with the inescapable trade-off between battery life and depth of discharge. Leaving batteries in the discharged state for extended periods causes premature failure. Some batteries can stand more of this type of use than others.

One way to ensure that batteries are not discharged excessively so that life can be maximized is to install an alarm system or automatic shut off mechanism (as described in Section 4.5.3) to operate when the battery is at a specified depth of discharge. A backup system such as a gasoline generator set can then be employed to return the batteries to full charge while providing for the appliance electrical needs. If no back up is employed, the designer has two options: 1) discharge the batteries more deeply (and pay for it in reduced life expectancy), 2) install additional battery capacity or, 3) wait for more sunshine.

The second approach may be perfectly acceptable because of the modular nature of battery systems. If it is found that more power is frequently needed than can be provided by a reasonable depth of discharge, additional batteries can be added. Of course, if the charging system (say the PV array) is 
inadequate to return the batteries to full charge in a typical daily cycle, then it must also be enlarged.

As a rule of thumb for initial system sizing, take your estimate of daily storage requirement from Table 4.1 and multiply by 10 to come up with an estimate of the total capacity of the battery system if you have a backup generator. If no backup is available, multiply anticipated essential energy needs by a factor of 15 to 25 to ensure adequate battery life. If the sun is frequently obscured and no backup battery chäger is available to provide for these cloudy periods, the array and battery system size must be increased.

One final check to make after sizing a battery system is to see if the maximum power output (amperes) of the PV array is less than 1/20th of the total amp-hour capacity of the battery system. This is because the maximum constant charge rate for conventional lead acid batteries should not exceed about $5 \%$ of the battery capacity.

The following section describes the key factors to keep in mind in selecting and using a battery system.

\subsubsection{Factors to Consider in Selecting and Using a Battery System}

Automotive type batteries are frequently not suitable for PV use. PV battery systems need:

- Deep Discharge Capability. Automotive type batteries are seriously damaged if fully discharged and left for any period of time. They are not designed for PV use. In a PV system the battery may be fully discharged occasionally.

o Adequate Life. The life will be related to the number of charge/ discharge cycles and to the depth of the discharge/charge cycle.

- High Charge/Discharge Cycle Efficiency. The efficiency of the battery and charge controller together should be about $80 \%$ or better for normal operation. If this isn't true, a larger PV array would be needed to make up the difference. A good PV battery will only consume internally $2 \%$ to $4 \%$ of its full charge per month. Automotive type batteries may self-discharge as much as $30 \%$ of their full charge in a month without any outside power load. 
- Maintenance. Maintenance free batteries are available for PV use, and may be important for use by those who don't intend to become "knowledgeable" about storage batteries. Other types of batteries absolutely require some maintenance (water level adjustment etc.) to prevent premature failure.

- Safety. Batteries are safely used by the millions in automobiles. They are inherently safe when used properly, but they typically contain strong acids, and they can generate hydrogen gas which is highly explosive. Large quantities of batteries should be isolated from living quarters in well vented enclosures. Suppliers should be consulted about housing and protecting batteries. Ordinary batteries can be fitted with "hydrocaps" which help them behave like maintenance free batteries. They are available from Hydrocap Corporation.

0 Freeze Protection and Shading. In northern climates batteries need freeze protection. Batteries fully charged are quite resistant to freezing although they may have drastically reduced capacity. Your car may not start well on cold mornings because of this problem. Specially designed batteries can be obtained so that they won't freeze even if discharged; however, they still won't put out full power when cold. It may well pay to build a separate underground protective enclosure in northern climates where freezing and cold weather are encountered. In warmer climates an underground enclosure can prevent excessive over-heating and help prolong satisfactory battery operation with reduced maintenance.

- Convenience. In some uses, gel electrolyte batteries are convenient since they can be over-turned without spilling corrosive acid.

Sumarizing, when buying a battery system, there are several factors to consider and you should be alert to the factors listed below when examining the various battery systems offered.

- Cost and Life. What are the tradeoff between initial costs and life expectancy?

- Storage Capacity. How many days can you operate "without sunshine"? 
- Efficiency. Does the battery selection affect the size of PV array needed?

- Ruggedness. Can the battery withstand the conditions of use; i.e., the amount of discharge it may encounter, etc.? Is it physically designed to cope?

- Safety and Reliability. What costs if any will be required to make the system safe and reliable? Do you need a special building, etc.?

- Maintenance. How much maintenance is required?

The battery field is very dynamic and we cannot possible list all suitable batteries. Several firms that specifically contacted us and asked to be mentioned as suppliers of P.V. batteries are included in Table 4.9 .

TABLE 4.9. Example Suppliers of PV Batteries

\begin{tabular}{|c|c|c|c|}
\hline Supplier & Description \& Comments & Rating & Ipprox. Price \\
\hline C\&D Battery Co. & $\begin{array}{l}\text { Type "Q,P" stationary very deep } \\
\text { discharge batteries (extra } \\
\text { heavy duty) }\end{array}$ & $96-936 \mathrm{Ah}$ & $\$ 165$ to $\$ 522$ \\
\hline C\&D Battery Co. & $\begin{array}{l}\text { Type DCP, KCP, LCP medium } \\
\text { discharge long life batteries }\end{array}$ & $42-2880$ Ah & $\$ 143$ to $\$ 1015$ \\
\hline Cullen Enterprises & $\begin{array}{l}\text { 8DVDH medium discharge \& } \\
\text { 8DVXXH deep cycle, long life }\end{array}$ & 220-300 Ah & $\$ 190$ to $\$ 260$ \\
\hline $\begin{array}{l}\text { Solarwest } \\
\text { Electric and } \\
\text { ARCO Solar }\end{array}$ & $\begin{array}{l}\text { Delco Type } 1 \text { batteries main- } \\
\text { tenance-free construction in } \\
\text { "automotive style" case }\end{array}$ & $\begin{array}{l}105 \mathrm{Ah} \\
12 \vee \mathrm{DC}\end{array}$ & $\$ 165$ \\
\hline $\begin{array}{l}\text { Exide/Energy } \\
\text { House }\end{array}$ & $\begin{array}{l}\text { PHV DE } 306 \mathrm{~V} \text { deep cycle batt- } \\
\text { ery in "automotive style" case }\end{array}$ & $\begin{array}{l}6 \mathrm{~V}, 185 \text { Ah } \\
\text { (use } 2 \text { for } \\
12 \mathrm{~V}, 0185 \\
\text { Ah) }\end{array}$ & $\begin{array}{l}2 \text { for about } \\
\$ 200\end{array}$ \\
\hline $\begin{array}{l}\text { Free Energy } \\
\text { Systems, Inc. }\end{array}$ & $\begin{array}{l}\text { Globe Union, Gel Cell deep } \\
\text { discharge type, sealed, } \\
\text { "long life" }\end{array}$ & $\begin{array}{l}28 \mathrm{Ah} \\
12 \mathrm{~V}\end{array}$ & \\
\hline Gates & $\begin{array}{l}0800-0016 \text { sealed } 12 \mathrm{~V} \text { lead } \\
\text { acid batteries }\end{array}$ & $\begin{array}{l}5.2 \text { Ah } Q \\
12 \vee D C\end{array}$ & NA \\
\hline Surrette & 301 M marine battery & $\begin{array}{l}6 \mathrm{~V} 230 \mathrm{Ah} \\
(2 \text { for } 12 \mathrm{~V} \\
230 \mathrm{Ah})\end{array}$ & $\begin{array}{l}2 \text { for about } \\
\$ 200\end{array}$ \\
\hline
\end{tabular}


The solar module supplier or dealer may make recommendations of additional suppliers of batteries. The book, How to Design an Independent Power System, by T. D. Paul has many practical suggestions about batteries (see reading list).

\subsection{SELECTING POWER CONDITIONING EQUIPMENT}

This section discusses the various power conditioning equipment which is necessary and available to ensure stable, safe, and efficient operation. The equipment falls into three categories; power controllers, inverters, and battery monitors.

\subsubsection{Power Controllers}

The use of PV panels to charge batteries wouldn't require any controls or electronic devices if you could disconnect the panels at night and in the afternoon. This will keep the modules from using power out of the battery at night and prevent the batteries from overcharging in the afternoon. It is assumed that you would remember to reconnect the array to the battery when the battery gets "low". In some applications such as warning beacons, batteries and PV arrays can be matched so well that the batteries will never overcharge.

The ARCO Company has designed a little black box to do just exactly that task for you. It has a switch (actually a relay) which is controlled by an electronic circuit called a universal charge controller (UCC). Most UCCs are available to operate on voltages of 12-48 volts nominal system voltage. It can even be ordered with a special probe to sense the temperature of the batteries, and to adjust its operation to the exact voltage the battery should have when fully charged at that temperature. It can handle up to $25 \mathrm{~A}$ of current from panels at $12 \mathrm{~V} D \mathrm{DC}$ and can handle up to $1 \mathrm{~kW}$ of panels at $48 \mathrm{~V}$ DC nominal voltage. The UCC unit sells for about $\$ 325$ from Solarwest Electric.

However, there are disadvantages to this device -- it does have mechanical contacts whereas approaches subsequently described are solid-state and eliminate this problem (but have other disadvantages). It uses about $70 \mathrm{~mA}$ at $12 \mathrm{~V}$ $D C$ during charging and uses $15 \mathrm{~mA}$ at $12 \mathrm{~V} \mathrm{DC}$ the rest of the time.

The most widely used approach for small systems is to omit the charge controller but to place a "diode" (or one way valve) in series with the array 
to keep the current from flowing back out of the battery and through the array at night. This diode is usually called a blocking diode and can be ordered right in the module. In small systems there is less liklihood of overcharging the battery and even if it does occur it is not serious if battery water levels are maintained. Diodes are not needed and shouldn't be used with the UCC described above because they would consume power during the charging process.

Where a system is to be used under changing load conditions some sort of charge control is needed in addition to the "blocking diode." A commonly used approach is the "shunt regulator". The device turns on some extra load when the battery is fully charged and its voltage gets too high. It "shunts" or bypasses the current away from the battery until the battery gets low and needs to be charged again. Some people will be able to remember when automobiles had no regulation of battery voltage and on long trips it was advisable to turn on the headlights to keep from boiling away the battery water. The shunt regulator does a similar job using a solid-state switch to connect a resistor which uses up the excess power.

The disadvantage of the shunt regulator is that it does generate a lot of heat which has to be dissipated. For this reason, they are fairly large. A line of shunt regulators available from Solar Power Corporation is shown in Table 4.10. They are less expensive than the UCC for small systems. These

TABLE 4.10. Solar Power Corporation Voltage Regulators

\begin{tabular}{lcc} 
Model Number & $\begin{array}{c}\text { Typical Regulating } \\
\text { Voltage (Volts, DC) }\end{array}$ & $\begin{array}{c}\text { Current } \\
\text { (Amps) }\end{array}$ \\
\cline { 2 - 2 } BVR12-0.6 & 14.7 & 0.7 \\
BVR6-1.2 & 7.35 & 1.4 \\
BVR12-2.0 & 14.4 & 2.5 \\
BVR12-2H & 14.4 & 2.5 \\
BVR12-6.0 & 14.4 & 7.35 \\
BVR12-12* & 14.4 & 1.4 .4 \\
BVR24-0.7 & 28.8 & 0.7 \\
BVR24-2.0 & 28.8 & 2.5 \\
BVR24-6.0 & 28.8 & 7.5
\end{tabular}

* $\overline{\text { Supersedes Mode } 1}$ BVR12-10 
shunt regulators $c$ an be ordered with temperature compensation and with high and low voltage alarms. They can also be ordered with special adjustment of the operating voltages.

Motorola Corporation has designed a clever shunt voltage regultor system where one master unit can be used to dissipate up to $100 \mathrm{~W}$ and it in turn can control as many $80 \mathrm{~W}$ slaves as needed to keep the battery bank from overcharging and to handle the charging current. The master MSPR 125 LXX is avai1able for about $\$ 125$ each and the slaves KISPR 125 LS for about $\$ 100$ each. Complete information should be obtained from Motorola or their dealer in your area. These units do have temperature compensation and contain "blocking diodes". With this system blocking diodes don't have to be ordered with the modules. The regulators should be ordered in sufficient quantity for the system so that they don't get overloaded.

Considerable creativity is emerging in the areas of controllers. Jim Cullen Enterprises has several controllers including a controller that dumps excess power into a resistance coil inserted into a hot water tank.

Arco Solar has a "Battery Protector" load management controller that will switch off low priority loads when the battery is low and reconnect them when the battery is properly charged.

Solarwest Electric has developed a charge controller. Specialty Concepts has a charge controller "the sun charger" designed to switch loads from the battery to the solar modules when they are making enough power so that the power does not go through the battery.

It is very wise to discuss the system to be regulated with the supplier of the regulator so that good results are attained. Usually the module/array supplier will design and supply (for a fee of course) a regulator just for your needs. The previous discussion won't really be needed in this case, but it may help you to discuss your needs with the supplier. He will want to know the battery type (lead acid, lead calcium, etc.) and will, of course, know the array size you are ordering and be able to supply adequate voltage regulator capacity for excellent system performance. 
If no batteries are used, and if your devices to be connected can tolerate the high voltage generated by an unloaded panel, you won't need any power controllers. So called "sun synchronous" application, with a motor or other load matched up to the panel, will have no difficulty under normal conditions. An unloaded $1 / 2 \mathrm{hp} D C$ motor may not load a $450 \mathrm{~W}$ array enough to keep the voltage in the normal operating range, but shunt type battery charge controllers can be used for this purpose even though batteries aren't used. We recommend that you discuss these applications with the module supplier.

\subsubsection{DC to AC Conversion}

The most efficient way to use the power generated by PV panels, in small systems, is to use it in the $D C$ form in which it is generated. For this reason many PV systems have started out as pure $12 \mathrm{VDC}$ systems. Most of the major needs such as pumping, refrigerating, and lighting can be provided by 12 $V D C$ appliances and products. However, sooner or later the user of a pure DC system will want to operate $A C$ appliances. It is quite natural to want to add some of the regular $A C$ appliances over a period of time and a straightforward way to handle this problem is to add devices to change some of the $D C$ to $120 \mathrm{~V}$ AC. These devices are called inverters.

There are a wide variety of inverters available and we will decribe some representative inverters for the major uses. Most PV module suppliers can supply inverters or suggest sources.

Inverters naturally fall into several classes as follows:

- Superlight duty for intermittent use with specific small appliances such as electric razors -- operated from battery systems.

- Medium duty for use with light hand drills, etc. and small appliances that have modest starting surges -- operated from $12 \mathrm{~V}$ battery systems.

- Heavy duty inverters for use in starting and operating heavy duty appliances such as large AC refrigerators, air conditioners, table saws, etc. that have a requirement for starting surges about six times the normal full load current -- operated from a DC battery bank. 
- Low cost inverters which connect to the electric power company lines don't use batteries at all and can't operate when the utility power is shut down.

0 "High quality*" inverters which can connect to the power line or operate in a "stand alone" mode connected to a battery

The superlight inverter is made to be used right with the appliance such as an electric razor. Since inverters do draw current, they should be shut off when the appliance is not in use. No special house wiring is required and they do the job very well within the limits of their design. Some of these superlight inverters are listed in Table 4.11.

* The "high quality" sine wave inverter may be better for operating computers or special equipment. However, heavy duty inverters may be a better choice for starting motors according to published accounts.

TABLE 4.11. Superlight Inverters from Jim Cullen Enterprises

\begin{tabular}{|c|c|c|c|}
\hline Supplier & Description & $\begin{array}{l}\text { Output } \\
\text { Wattage } \\
\text { (Cont.) } \\
\end{array}$ & Price \\
\hline \multirow[t]{5}{*}{ ATR } & $\begin{array}{l}\text { Type 12U-RSF complete } \\
\text { with cables }\end{array}$ & 150 & $\$ 141$ \\
\hline & $\begin{array}{l}\text { Type } 12 \text {-DME with cigar- } \\
\text { ette lighter adapter }\end{array}$ & 40 & $\$ 65$ \\
\hline & $\begin{array}{l}\text { Type } 12-\text { RME-1 with cigar- } \\
\text { ette lighter adapter }\end{array}$ & 110 & $\$ 99$ \\
\hline & $\begin{array}{l}\text { Type IL-SPB "Shav Pak" } \\
\text { with cigarette lighter } \\
\text { adapter }\end{array}$ & 25 & $\$ 53$ \\
\hline & $\begin{array}{l}\text { Sine wave adapter produces } \\
\text { "true" sine wave with above }\end{array}$ & & $\$ 60$ \\
\hline \multirow[t]{3}{*}{ Tripp-Lite } & PV 115 & 100 & $\$ 60$ \\
\hline & PV 200 & 200 & $\$ 75$ \\
\hline & PV 500 & 500 & $\$ 159$ \\
\hline
\end{tabular}


They do consume power when left connected even when the razor, etc. is turned off. They may be fairly inefficient, but this effect is small if their use is limited to short duration on an occasional basis. They may generate considerable noise both audible and electrical. Their electrical noise may be translated into audible noise ("static") in a radio or high-fi.

The medium duty inverters are available for operating small appliances, electric razors, light power tools, etc. They should be operated below their maximum rating and should be turned off when not in use. Some inverters are available with a "load demand start" feature which allows use without worrying about turning the inverter on or off. This feature should be ordered even though it costs a little extra since it can save your battery supply by eliminating the consumption of standby power. A word of caution is in order here! Demand control of start and stop works well for "normal" loads, but users report that for very light loads (i.e., small radio), some automatic start controls do not start. Manual override switches would appear to be a solution to the problem. The units listed in Table 4.12 don't have enough surge capacity for starting large AC induction motors.

TABLE 4.12. Medium Duty Inverters 12 V DC to $120 \mathrm{~V}$ AC

\begin{tabular}{|c|c|c|c|c|}
\hline $\begin{array}{l}\text { Model \# \& } \\
\text { Supplier }\end{array}$ & $\begin{array}{l}\text { aximum Watts } \\
\text { ont inuous } \\
\text { utput }\end{array}$ & $\begin{array}{l}\text { Maximum Watts } \\
\text { Peak Output }\end{array}$ & $\begin{array}{l}\text { Input Watts } \\
\text { No Load }\end{array}$ & $\begin{array}{l}\text { Approx。* } \\
\text { Price }\end{array}$ \\
\hline $\begin{array}{l}\text { PV-250 FC } \\
\text { Solarwest } \\
\text { Electric }\end{array}$ & 250 & 275 & 18 & $\$ 185$ \\
\hline 1057, Wilmore & 300 & NA & NA & $\$ 400$ \\
\hline $\begin{array}{l}\text { PV-500 FC } \\
\text { Solarwest Electr }\end{array}$ & ric $^{500}$ & 550 & 42 & $\$ 300$ \\
\hline 1403, Wilmore & 500 & 1000 & NA & $\$ 600$ \\
\hline $\begin{array}{l}\text { PV-1000 FC } \\
\text { Solarwest } \\
\text { Electric }\end{array}$ & 1000 & 1100 & 42 & $\$ 450$ \\
\hline B-5 Dynamote & 500 & 1000 & \multirow{3}{*}{$\begin{array}{l}\text { Available with } \\
\text { demand control } \\
\text { of start \& stop. }\end{array}$} & \\
\hline B-10 Dynamote & 1000 & 2000 & & $\$ 840$ \\
\hline B-18 Dynamote & 1800 & ، 3500 & & $\$ 990$ \\
\hline $\begin{array}{l}\text { Best B-12-1000 } \\
\text { Solarwest } \\
\text { Electric }\end{array}$ & 1000 & 4000 & $18 W$ & $\$ 1,199$ \\
\hline
\end{tabular}

* Without load demand start and stop (add $\$ 100-\$ 200$ for this feature). 
Heavy duty inverters are required for starting large AC induction motors because they require as much as six times the normal running current (i.e. surge) starting period. Table 4.13 supplied by T.D. Paul of Best Energy Systems compares the starting and running watts for typical AC induction motors. He has a number of practical suggestions in his book, How to Design an Indepndent Power System, for those considering their own system.

TABLE 4.13. Comparison of Starting and Running Power for AC Induction Motor

Horsepower

$1 / 6$

$1 / 4$

$1 / 3$
Start/Run Watts

$1500 / 325$

$3000 / 525$

$4500 / 725$
Horsepower

$1 / 2$

$3 / 4$

1
Start/Run Watts

$6000 / 1000$

$8000 / 1400$

$10,000 / 1800$

Table 4.14 lists some representative units that have high surge capacity.

TABLE 4.14. Heavy Duty Inverters for Operating Induction Motors \& 0ther Loads at $120 \mathrm{~V}$ AC

\begin{tabular}{|c|c|c|c|c|c|c|c|c|}
\hline $\begin{array}{l}\text { Model \& } \\
\text { Supplier }\end{array}$ & $\begin{array}{l}\text { Maximum } \\
\text { Cont inuous } \\
\text { Load }\end{array}$ & $\begin{array}{l}\text { Surge } \\
\text { Load }\end{array}$ & $\begin{array}{l}\text { Battery } \\
\text { Voltage } \\
\text { Nominal }\end{array}$ & $\begin{array}{l}\text { No Load } \\
\text { Input (!I) }\end{array}$ & $\begin{array}{l}\text { Universal } \\
\text { Tool } \\
\text { Rating } \\
\end{array}$ & $\begin{array}{l}\text { AC Indi } \\
\text { Motor } \\
\text { Rating }\end{array}$ & uction & $\begin{array}{l}\text { Approx. } \\
\text { Price }\end{array}$ \\
\hline $\begin{array}{l}\text { Dynamote: } \\
\text { B18-24 }\end{array}$ & 1,800 & $3,600 \mathrm{~W}$ & 24 & $\begin{array}{l}\text { Available with } \\
\text { load demand } \\
\text { control of } \\
\text { starting \& } \\
\text { stopoing. }\end{array}$ & NA & 0.5 & $H P^{\circ}$ & S 990 \\
\hline $\begin{array}{l}\text { Best/Solar } \\
\text { Electric: } \\
\text { BR-24-2500 }\end{array}$ & 2,500 & 10,000 & 24 & $40 \star \star$ & $3 \mathrm{HP}$ & 0.5 & HP & 1,749 \\
\hline $\begin{array}{l}\text { Dynamote: } \\
\text { B30-24 }\end{array}$ & 3,000 & 6,000 & 24 & $\begin{array}{l}\text { Available with } \\
\text { load demand } \\
\text { control of } \\
\text { starting \& } \\
\text { stopping. }\end{array}$ & PIA & 1 & HP & 1,350 \\
\hline $\begin{array}{l}\text { Best/Solar } \\
\text { Electric: } \\
\text { B-48-5000 }\end{array}$ & 5,000 & 20,000 & 49 & $70 \star \star$ & $6 \mathrm{HP}$ & 2 & HP & 2,720 \\
\hline $\begin{array}{l}\text { Dynamote: } \\
\text { MB } 60-48 \text { * }\end{array}$ & 6,000 & 18,000 & 48 & $\begin{array}{l}\text { Available with } \\
\text { load demand } \\
\text { control of } \\
\text { starting \& } \\
\text { stopping. }\end{array}$ & NA & 2 & HP & 2,400 \\
\hline
\end{tabular}

*Includes load demand start and stop control and other features to make it suitable for marine use.

$\star \star$ Manufacturer is adding load demand start. 
The invertors we have discussed up to this point are all solid-state units and most claim efficiencies in the range of $85 \%$ for loads of $25 \%$ or more of full continuous load inverter rating. "Wave shape" produced by these inverters is not a "sine wave" (the smooth ideal wave shape for AC). They all have some variation from this ideal. The amount of variation partially explains the differences in price. Best's B-48-5000 and Dymamote's B-60-48 has specifically been recommended by the manufacturer as having the capability to start and operate typical household appliances. If a 5,000 $\mathrm{W}$ range inverter is used to operate freezers, etc., so that it has to be left on, it will consume up to 1.7 $\mathrm{kWh} /$ day just in standby power. If left turned on $24 \mathrm{hrs} /$ day, it would quickly discharge a small PV systems batteries even if no load is connected. Because of this, some users have two inverters, a small one to operate small appliances and a large one to operate larger equipment on an occasional basis. This adds up to an argument for a hybrid system where $D C$ appliances are used, whenever possible in small systems, and $A C$ inverters are used for powering equipment that it isn't practical to power from DC. In large systems with many loads, it is probably simpler to operate the inverter full time and add enough panels to handle the loads and the standby power of the inverter. All of the units listed so far are designed to operate from storage batteries, and none has been intended for connection to a power line in order to feed excess power back to the utility.

Low cost inverters for connecting utilities are a special type of inverter for feeding power from a $D C$ source into the utility grid. The advantage of this design is: a) low cost b) its ability to feed power back into a utility system from a PV array without any battery storage, c) the ability to handle wide voltage changes, and d) very high efficiency. The disadvantages are that this design will not operate away from the utility and the "wave shape" of the current produced isn't the same as that produced by the utilities. This could produce special problems. If several inverters were to be operated from the same utility distribution transformer, serious problems might be encountered. On the other hand, your utility may have no problem at a11 (at least 600 are operating in the U.S. at the present time). In any case don't $\mathrm{plan}$ to connect any inverter to the utility AC power system without checking with the utility first. These inverters are called the Gemini 
series and are produced by WINDWORKS, Inc. Their approximate prices range from about $\$ 1 /$ watt in smaller sizes to about $\$ 0.18 / \mathrm{W}$ for the $150 \mathrm{~kW}$ unit. This is well below the costs for other types of synchronous (or utility connected) inverters. Some of the ratings available and approximate prices are shown in Table 4.15 .

There are a number of developments in "high quality"* inverters which will bring additional products into this market where good "wave form" is produced and the inverter is to be operated with or without $A C$ power line interconnections. The Nova Electric Manufacturing Company and the Topaz, Powerwork Divison make a number of "high quality" sine wave inverters. These are listed in Table 4.16. Abacus Controls makes a line of DC to AC inverters (Table 4.16) to operate with a $D C$ input voltage of $120 \mathrm{~V}$ and another Sunverter line operating with $200 \mathrm{~V} D C$ (nominal) input (160-240 V DC with or without battery). Part of the Sunverter line is described in Table 4.16. Prices are about $\$ 5 /$ volt ampere where $V A$ is a product of load voltage in volts and load current in amperes at a $250 \mathrm{VA}$ rating and go down to about $\$ 1.70 / \mathrm{VA}$ at 10,000 VA rating. The "suninverters" can operate in a stand alone mode or can be supplied to

* The "high quality" refers to purity of wave shape which is not needed in many applications.

TABLE 4.15. Ratings Available and Approximate Prices for Gemini Synchronous Inverters

$\begin{array}{rc}\begin{array}{c}\text { Ratings } \\ \text { (kW) }\end{array} & \text { Approximate Price } \\ 4 & \$ 4,072 \\ 8 & 4,936 \\ 10 & 6,180 \\ 15 & 8,393 \\ 20 & 12,000 \\ 40 & 13,700 \\ 50 & 16,500 \\ 100 & 22,100 \\ 150 & 27,000\end{array}$


TABLE 4.16. High Quality Sine Wave Inverters $120 \mathrm{~V} \mathrm{AC}, 60 \mathrm{~Hz}$ output

\begin{tabular}{|c|c|c|c|}
\hline $\begin{array}{l}\text { Model and } \\
\text { Supplier }\end{array}$ & $\begin{array}{c}\text { Output } \\
\text { Power (VA) } \\
\end{array}$ & $\begin{array}{c}\text { Input } \\
\text { Voltage } \\
\end{array}$ & Approximate List Price\$ \\
\hline $\begin{array}{l}1260-12 \\
\text { Nova }\end{array}$ & 125 & 12 & 485 \\
\hline $\begin{array}{l}250 \text { GZ } 12 / 24 \\
60-15 \\
\text { Topaz }\end{array}$ & 250 & $12 / 24$ & 1,190 \\
\hline $\begin{array}{l}2560-12 \\
\text { Nova }\end{array}$ & 250 & 12 & 690 \\
\hline $\begin{array}{l}500 \text { GZ } 12 / 24- \\
60-115 \\
\text { Topaz }\end{array}$ & 500 & $12 / 24$ & 1,720 \\
\hline $\begin{array}{l}5060-12 \\
\text { Nova }\end{array}$ & 500 & 12 & 975 \\
\hline $\begin{array}{l}1000 \text { GZ }-12 / 24- \\
60-115 \\
\text { Topaz }\end{array}$ & 1,000 & $12 / 24$ & 2,310 \\
\hline $\begin{array}{l}1 \text { K60-12 } \\
\text { Nova }\end{array}$ & 1,000 & 12 & 1,765 \\
\hline $\begin{array}{l}443-4-120 \\
\text { Abacus }\end{array}$ & 4,000 & 120 & 7,130 \\
\hline $\begin{array}{l}5 \mathrm{~K} 60-120 \\
\text { Nova }\end{array}$ & 5,000 & 120 & 5,070 \\
\hline $\begin{array}{l}463-4-120 \\
\text { Abacus }\end{array}$ & 6,000 & 120 & 10,380 \\
\hline $\begin{array}{l}\text { lok } 60-120 \\
\text { Nova }\end{array}$ & 10,000 & 120 & 9,145 \\
\hline $\begin{array}{l}483-4-120 \\
\text { Abacus }\end{array}$ & 10,000 & 120 & 13,820 \\
\hline $\begin{array}{l}743-4-200 \\
\text { Abacus }\end{array}$ & 4,000 & $160-240$ * & 9,360 \\
\hline $\begin{array}{l}763-4-200 \\
\text { Abacus }\end{array}$ & 6,000 & $160-240 *$ & 12,240 \\
\hline $\begin{array}{l}714-4-200 \\
\text { Abacus }\end{array}$ & 10,000 & $160-240 \star$ & 17,050 \\
\hline
\end{tabular}


operate connected to a utility power line. The wave form is much closer to the ideal with this type of inverter than with the lower cost version. In spite of this do not plan to connect to the power company without checking with the power company first.

American Power Conversion Corporation and Advanced Energy Corporation are reported to be close to issuing catalogs on synchronous and stand alone inverters in the 2 to $8 \mathrm{Kw}$ range.

A special word of caution here, we recommend that you get assistance from experienced designers and installers of these inverters that connect to the power line. There are many potential problems we can't discuss here including safety issues, laws, rules, and regulations that must be followed in these installations. The inverter manufacturers may be willing to assist with these problems.

The problems associated with smaller stand alone inverters are more manageable by the knowledgeable do-it-yourselfer. They are being used by do-ityourselfers already. This isn't the case for the utility connected inverters right now. As time passes, the problems will be better understood and less skill will be required to install these utility connected systems. In addition to Windworks and Abacus, there are other companies able to design inverters for various applications including Helionetics and Applied Research and Technology Corporation of Utah (ARTU).

In summary, inverters can supply $A C$ from $D C$ sources for most reasonable home and light industry needs. At present PV costs, it is better to use high efficiency DC appliances where possible, especially where the use is fairly continuous. Occasional use appliances can be supplied with AC from very efficient inverters and add much to the enjoyment of the PV power system. A very small inverter $(200 \mathrm{~W})$ can supply a sewing machine or portable mixer.

\subsubsection{DC to DC Conversion}

Selecting system DC voltages presents some challenge. There are advantages and disadvantages to any voltage that may be selected. A choice is available wherever several $12 \mathrm{~V} D C$ solar panels and $12 \mathrm{~V}$ batteries are used to store the energy. The panels can be connected in parallel to charge the batteries at 12 $V$ or connected in series for a higher voltage: $24,36,48$, etc. 
The 12 V DC system has considerable advantage in reduced shock hazard, and because there are numerous appliances designed for $12 \mathrm{~V} D C$ use. Two problems exist with the $12 \mathrm{~V}$ system choice. One is that larger wires are required for carrying the lower voltage, and in larger PV systems heavy duty inverters are often selected that must be supplied with a voltage higher than twelve.

If a higher voltage is selected, a DC to DC converter will be needed to produce $12 \mathrm{~V}$ for many $\mathrm{DC}$ appliances.

A seemingly simple solution to the problem is to hook a resistor in series with the appliances to be powered from the higher voltage source. This approach is not recommended because it can destroy the appliance under certain conditions, and there are situations where this approach can be used safely, but it is especially hazardous for sensitive electronic equipment with a wide variation in current consumption during normal operation. For instance, a C.B. radio may use twice as much current during transmission compared to standby and listen mode. In this case, if you select the dropping resistor for the correct voltage during listen operation, the radio would get only about half voltage during attempts to transmit. Selecting the resistor for transmission mode would greatly overvoltage the appliance during the receiving mode.

DC to DC converters can match the supply voltage to the load voltage. They are available in a wide variety of voltages and power ratings. They do an excellent job of providing DC power for various appliances, but they consume some power during standby mode and should be switched off when the appliance is not needed. While being operated, they are typically about $80 \%$ efficient. Some examples of $D C$ to $D C$ converters are listed in Table 4.17 .

Many other converters and power supplies are available from Wilmore Electronics and other sources.

$D C$ to $D C$ converters are a satisfactory solution to the problems of operating DC appliances but they do have three disadvantages in that they: a) lose about $20 \%$ of the power they convert while being used, b) use power even during standby mode with no load attached, and c) add more complexity to the system and consequently add to system expense. Despite these disadvantages, they are likely to be used extensively as typical PV systems grow in size and power ratings and high-powered AC inverters demand higher DC supply voltages. 
TABLE 4.17. DC to DC Inverters

\begin{tabular}{|c|c|c|c|c|c|}
\hline $\begin{array}{l}\text { Item \# and } \\
\text { Supplier }\end{array}$ & $\begin{array}{r}\text { Nominal } \\
\text { Supply } \\
\text { Voltage } \\
\end{array}$ & $\begin{array}{r}\text { Nominal } \\
\text { Output } \\
\text { Voltage } \\
\end{array}$ & $\begin{array}{l}\text { Output } \\
\text { Current }\end{array}$ & $\begin{array}{l}\text { Standby } \\
\text { Power } \\
\text { (No Load) }\end{array}$ & $\begin{array}{l}\text { Approx. } \\
\text { Price }\end{array}$ \\
\hline $\begin{array}{l}8424 \\
\text { Solarwest } \\
\text { Electric }\end{array}$ & $24 \mathrm{DC}$ & $12 \vee \mathrm{DC}$ & $\begin{array}{l}12 \mathrm{~A} \\
\text { Peak }\end{array}$ & $N A$ & $\$ 250$ \\
\hline $\begin{array}{l}\text { Model } 1365 \\
\text { Wilmore } \\
\text { Electronics }\end{array}$ & $24 \mathrm{DC}$ & $12 \vee \mathrm{DC}$ & $\begin{array}{l}10 \mathrm{~A} \\
\text { Cont inuous } \\
15 \mathrm{~A} 20 \% \\
\text { Duty Cycle }\end{array}$ & 4 Watts & $\$ 175$ \\
\hline $\begin{array}{l}\text { Model } 1265 \\
\text { Wilmore } \\
\text { Electronics }\end{array}$ & $\begin{array}{l}24 \text { or } \\
48 \vee \text { VC } \\
\text { (specify) }\end{array}$ & $12 * V D C$ & $30 \mathrm{~A}$ & 5 Watts & $\$ 648$ \\
\hline $\begin{array}{l}\text { Model 12-150 } \\
\text { Pacific Energy } \\
\text { Systems }\end{array}$ & $16-40 \vee D C$ & $13.8 \vee \mathrm{VCC}$ & $11 \mathrm{~A}$ & 1-2 Watts & $\$ 198$ \\
\hline
\end{tabular}

* Voltage is adjustable from $12 \mathrm{VDC}$ to $14 \mathrm{~V} D C$ by a screwdriver adjustment on the front panel and output is highly regulated from no load to full load from 20-29 V DC input or 40 to $58 \mathrm{~V}$ DC for the higher voltage model.

\subsubsection{Battery Monitors}

Alarm systems can be obtained to warn of low voltage or high voltage or of a 24 hour period with no power coming from PV modules. The module manufacturers are usually able to provide alarm capability. We are aware of two models available from ARCO Solar for $24 \mathrm{~V}$ and $48 \mathrm{~V}$ systems. The "AM 24 " or "AM 48" alarm device is well worth the $\$ 200$ to $\$ 300$ they are listed at. Dymamote also lists voltage guards for 12,24 and $36 \mathrm{~V}$ systems. They can warn that some loads must be dropped or other action taken.

\subsection{DESIGN REVIEW}

The purpose of this section is to assist you review your electrical needs and design a PV power system to meet them. First, we will highlight the most important factors from the previous sections, and then present an example calculation to demonstrate the design process. It will be helpful for you to refer to a copy of Table 4.1 as you study this material. 


\subsubsection{Estimating and Reviewing System Sizing}

The first task to be accomplished is to estimate the anticipated energy requirements. This is done by listing the appliances you intend to use in Table 4.1 according to whether $A C$ or $D C$ power is required for them. Enter the power requirements (watts) of the appliances under the second column. Remember to add 15\% (multiply requirements by 1.15 ) of the power requirements of $A C$ appliances listed to account for the power consumption of the required inverter.

Next you must estimate the hours of use for each of these appliances according to classes of need be they Class I (essential), Class II (priority), or Class III (optional). Under each of these classes enter the product of the number of hours times the power requirement for each appliance. This should be expressed in terms of watt-hours because you've multiplied the power requirement in watts times the number of hours of average daily use.

The next step is to estimate the storage requirements to size the battery storage system. For each appliance, estimate the percentage of time the appliance will be used when the sun is not shining. By multiplying this percentage by the daily energy requirement (i.e. watt hours) calculated above, you have a preliminary estimate of the amount of energy which needs to be extracted from batteries on an average daily cycle for each individual appliance.

Now total up the columns for the $D C$ appliances and the $A C$ appliances and enter them on the table. The next task requires you to anticipate the maximum power requirement which will occur with your system by adding up the requirements of those appliances which will possibly operate at the same time. The resulting total for the $A C$ appliances only is your inverter capacity requirement which should be entered in the power conditioning section. The peak simultaneous power requirement for both the $A C$ and $D C$ appliances should be inserted in the peak demand blank.

According to our rule of thumb, which is based upon conventional practice, we estimate the battery storage requirement. Enter the total of the storage requirement column ( $A C$ plus $D C$ ) in the Storage req blank in the battery sizing section. Enter 10\% for the depth of charge limit and multiply your storage 
requirement by 10 to determine your battery capacity requirement. If you live in a frequently cloudy area estimate the number of days which you expect cloudy conditions and enter in the number of days of storage blank. Add 10 to this number and multiply by the storage requirement to estimate the battery storage requirement.

Finally, we need to size the PV array required to keep the batteries sufficiently charged. Enter the sum of the $D C$ and $A C$ energy requirements in Class I and II and enter in the Average Daily Load blank under Array Sizing. Multiply the storage requirement calculated above by 0.20 and enter the result below. Sum the average daily load and the 0.2 times storage requirement figure and enter as the Adjusted Total.

The next step is to consult Figures 4.1 and 4.2 to determine the average sun hours in your location. If the PV system must provide all of the Class I and Class II needs at all times you must use the lowest of the sun hour figures. By dividing this figure into the Adjusted Total, you determine the Array size necessary in watts. By dividing this figure by the output watts of the modules selected, and rounding you have an estimate of the number of module panels needed for your installation.

By looking back through the tables on products available it is possible to estimate the cost of your system. Having gone through this exercise, you may wish to reconsider the appliances used or the hours of use to reduce the cost of the PV supply. An important factor to keep in mind in this effort is that the a Federal Tax Credit is available which provides a $40 \%$ tax credit for expenditures up to $\$ 10,000$ per year. The economic and other advantages of PV electric systems is discussed quite extensively in Chapter 6.

\subsubsection{Example System Design}

The best way to illustrate the design process is to do an example problem. We have arbitrarily selected an energy efficient retirement home to be located more than two miles from an existing utility line in the vicinity of Phoenix, Arizona. The house is earth sheltered and oriented to the south so as to minimize cooling requirements and negate the need for all but occasional heating. A solar hot water heater using a PV powered pump is installed to supply nearly al1 of the hot water requirements. 
Since the house is earth sheltered, and the climate is typically dry, evaporative cooling is sufficient to provide comfort on all but the hottest of days. Since both the water heater pump, and cooling energy requirements are sun synchronous we can dedicate arrays to those particular uses with no need for battery storage. The arrays for the cooling system can however be wired in such a way that they can provide power for other uses when the cooling system is not needed. Since water heating is needed year round, it is probably better for the water heater array to be isolated from the rest of the system.

Cooking, back up water heating, and space heating energy are assumed to be supplied by an LP gas system. The rest of the electrical needs are assessed using the suggested table. The four 33 watt (two 1200 CFM LA-9 Systems from Table 3.2) modules dedicated to the cooling system selected can be utilized as additional back up for periods of occasional cloudiness in the winter months, or to supply Class III (optional) needs when cooling is not required.

Our completed Table 4.1 is shown as Table 4.18.

Each of the entries is explained below:

- A portable 50 watt color TV is used for 3 hours in priority class and for 3 hours optional. It is estimated that $50 \%$ of the use occurs when the sun is not shining. The storage requirement is then $50 \%$ of 150 plus 150 or 150 .

- A small Hi-Fi Radio rated at 15 watts is used for 2 hours in priority class and 2 hours optional. Since $50 \%$ of use is without sun, storage req. is 30 watt-hours.

- A fan rated at 25 watts is used 4 hours daily, exclusively during the day so no storage is necessary.

- CB Radio rated at 12 watts is used for 1 hour in priority class and 2 hours options. $50 \%$ or use is without sun so storage req is 18 watthours.

- A smal1 36 watt refrigerator uses its compressor for 13 hours per day resulting in a Class I (essential) energy need of 480 watt-hours. It is assummed that $50 \%$ of the compressor on time occurs when the sun is not shining, resulting in a storage req. of 240 watt-hours. 
TABLE 4.18. Est imate of PV System Size

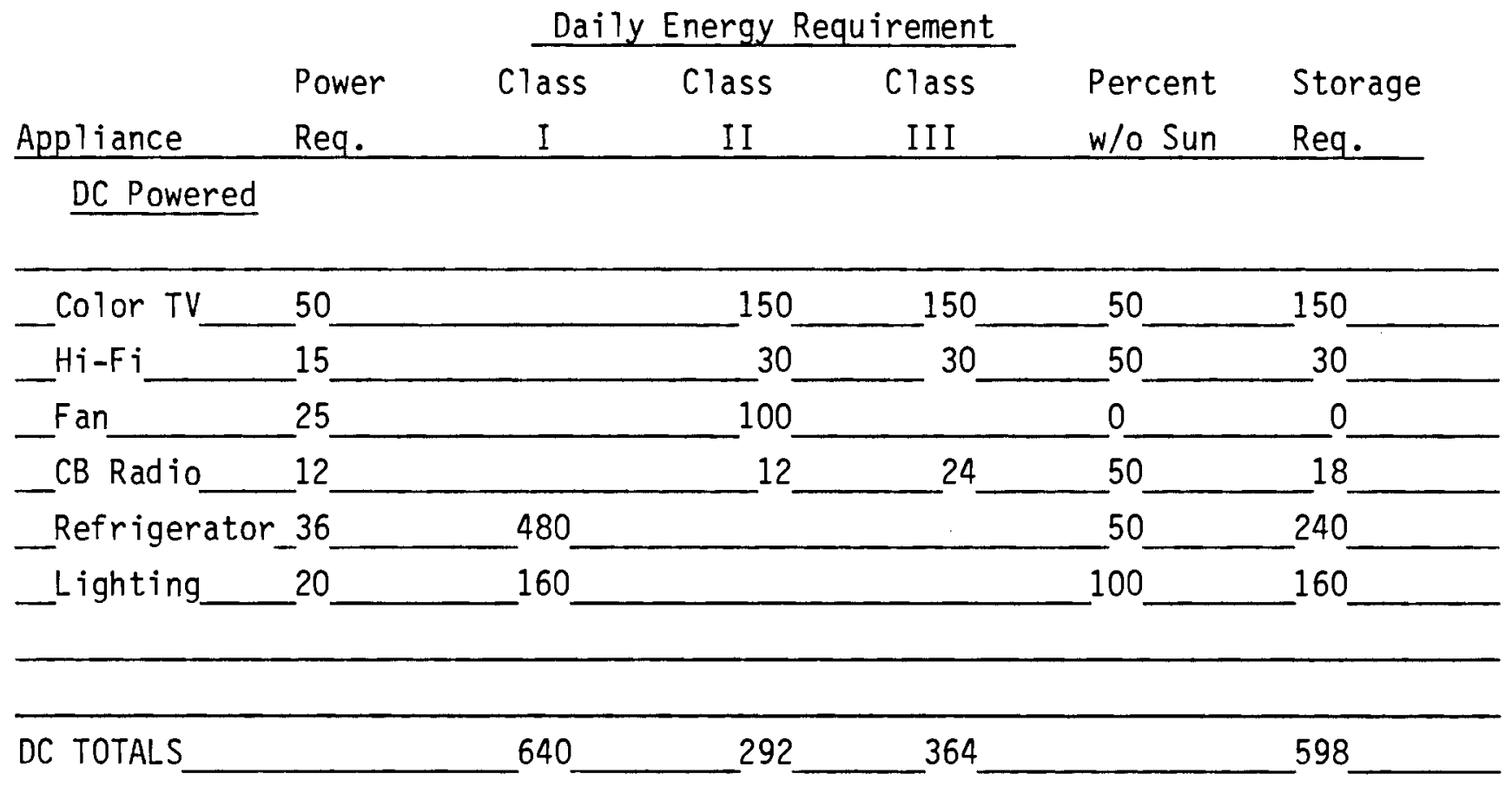

\section{$\underline{\text { AC Powered }}$}

\begin{tabular}{|c|c|c|c|c|}
\hline _Toaster_ 1150 & 288 & 288 & 25 & 144 \\
\hline Wash Mach. 575 & 173 & 173 & 0 & 0 \\
\hline _Vac. Cleaner 690 & 173 & 173 & 0 & 0 \\
\hline Hair Dryer 1380 & 173 & 173 & 50 & 173 \\
\hline \multicolumn{5}{|l|}{ AC TOTALS } \\
\hline & 807 & 807 & & 317 \\
\hline
\end{tabular}

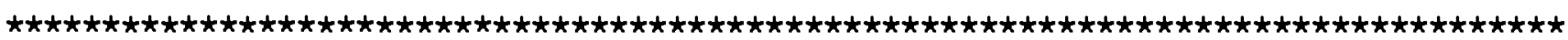

Peak Demands (watts): $1466 \quad$ Inverter Capacity: 1380

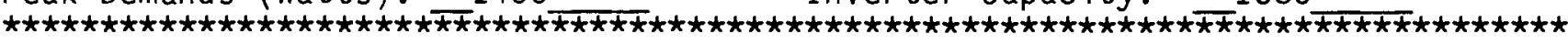
Battery Sizing

Storage Req.: _ 915 _ watt-hours Depth of Charge Limit: _ _ $10 \%$

Number of Days Storage: Battery Capacity Req.: 9,150

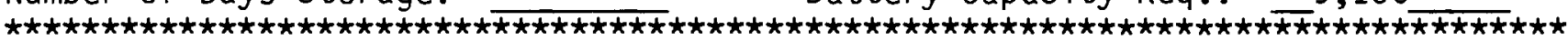
Array Sizing

Average Daily Load: $\quad 1739$ watt-hours Sun hours per day:
Storage Req X .2: $\quad 183$ watt-hours Array Size (watts): Adjusted Total: $\overline{1922}$ watt-hours Module Req:

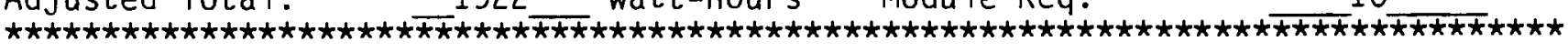


- Several 15 watt high efficiency DC lights are used for a total of 8 hours per night. (i.e. two lights for 4 hours each). Since all this use occurs when the sun is not shining it must all be stored in batteries.

- An AC toaster rated at 1000 watts is used for 15 minutes in priority use and 15 minutes optional. First the power req is increased by $15 \%$ to account for the inverter power req. Then this figure is multiplied by 0.25 ( $1 / 4$ hour) to yield an energy req. of 287.5 or say 288 watthours. $25 \%$ of the use is assumed to occur when the sun is not shining resulting in a storage req. of 144 watt-hours.

- A 500 watt washing machine is assumed to be used exclusively during the daytime for an average of 15 minutes per day in the priority class and 15 minutes optional. Although the typical washing cycle may be longer, this is the estimated time the motor is actually running. There are advantages of running one load daily over 7 loads once a week, because the batteries are more evenly discharged.

- A 600 watt vacuum cleaner is used for 15 minutes daily in priority mode and 15 minutes optional exclusively during the daytime.

- A 1200 watt hair dryer is used for 15 minutes of priority use and 15 optional. Half of the use is expected to occur when the sun is not shining requiring 173 watt-hours to be stored.

Next the columns have been totalled for the $D C$ and $A C$ appliances individually. To estimate power conditioning requirements we assume that the maximum load on the AC systems will occur when the hair dryer is operating alone. Consequently if a 1380 inverter is acquired the user must assure that no other $A C$ appliances are being used at the same time or else a fuse will blow. Another caution is to insure that the surge power requirements of the washing machine and vacuum cleaner do not exceed this figure.

The peak demand is assumed to occur when the hair dryer is used while the color TV is turned on and the refrigerator is running. The figure is the sum of 1380 plus 50 plus 36 or 1466 watts. The size of this number will depend upon the level of control over appliance use which is practicable or desired. 
We then sum the storage requirement of 598 for the DC appliances with the 317 watt-hours for the AC appliances and get 915 watt-hours which is entered in the appropriate space. Since the common rule of $10 \%$ depth of discharge is acceptable we determine that a battery system with 10 times the storage requirement is necessary to 1 imit average daily discharge to $10 \%$. This means that 9,150 watt-hours of storage is necessary. Since the weather in Phoenix is generally clear, no additional storage is deemed necessary.

Finally we size the array to supply the system. We add all the power requirements for both $A C$ and $D C$ needs in classes I and II to come up with a average daily load of 1739 watt-hours. This is the sum of 640,292 , and 807. The optional uses are assumed to be exercised only greater than average sun is collected or other loads have been reduced. To this we must add $20 \%$ of the storage requirements due to losses in the storage system. The adjusted total energy requirement is 1922 watt-hours per day.

To calculate the capacity of PV array necessary to supply our needs we must consult Figures 4.1 and 4.2 to determine the effective number of sun hours for our location. We use an average figure of 6 for the air-cooler panels can be diverted for other uses during the least sunny winter months. Dividing our adjusted total by 6 yeilds an array size of 320 watts. If ARCO 16-2000 modules rated at 33 watts each are used, 10 will be required.

Remember that in addition to the 4 panels assumed to be dedicated exclusively to the air coolers we have 1 panel dedicated to the solar water heater pump. Consequently our retirement home would require a total of fifteen 33 watt panels and about 10,000 watt hours of battery storage. Delco 2000 batteries rated at 105 amp hours each will hold 1260 watt-hours apiece (105Ah X 12 volts). Thus 8 batteries would be required.

Connectors and wiring should not be overlooked in the design process. They should be selected after the rest of the design system is complete. A connection diagram should be made before selecting the switches, fuses, circuit breakers and wiring and connectors.

Many of the "off-the-shelf" systems include switches, fuses, connector cables and/or a harness for connecting the system. 
One benefit of the photovoltaic power system is the inherent reliability of the solid state components of the system. In any electrical systems there are potential maintenance problems. The experienced troubleshooter expects that if all of the components are sound, the most common cause of difficulty would be faulty wire connections. To assure quality system performance, you should:

- Use large enough wires so that overheating does not occur (see the National Electrical Code as well as local codes). These wires become quite large in $12 \mathrm{~V}$ systems where substantial quantities of power are to be handled. Thus higher voltages are used as systems become larger.

- Solder the connections or use well designed terminals (Amp Inc. makes a wide variety of wire terminals and one line specifically suitable for PV terminals).

- Select insulation for wires and terminals that is suited to the environment they encounter.

o Protect the wires from future mechanical stress or abuse.

Properly installed wiring and connections add greatly to trouble-free enjoyment of the system.

Using prices listed in Tables 4.7, 4.9 and 4.12, we determine the following system costs:

15 ARCO Solar Modules o $\$ 450$ each................. $\$ 6,750$

8 Delco Batteries a $\$ 165$ each.................... $\$ 1,320$

1 Dynamote B-18 Inverter ........................ \$ 990

1 UCC Charge Controller........................... \$ $\$ 325$

TOTAL........................................... $\$ 9,385$

The only recurrent cost is replacement batteries approximately every 5 years, meaning that once the system without batteries is paid for at a price of $\$ 8,165$ the only anticipated operating cost is approximately $\$ 264$ per year for batteries $(\$ 1,320$ divided by 5$)$. After taking advantage of the $40 \%$ Federal Tax credit, the net system cost without batteries is less than $\$ 5000$. How this compares with available alternatives is discussed in Chapter 6.0 
. 


\subsection{CUSTOM-BUILT COMPONENTS AND SYSTEMS}

The PV industry has the ability to meet most consumer's needs with off-theshelf components and systems described in Chapters 3.0 and 4.0. However, in those applications where off-the-shelf items will not suffice, several options exist: a) purchase a special order system, b) design and build your own custom system, or c) have someone else design and build you a custom system.

This chapter describes a few of the many custom PV systems already in operation to give the reader an idea of the flexibility and ingenuity of the PV industry. Next, we have compiled a list of PV firms who have expressed the capability of providing custom systems.

\subsection{CUSTOM SYSTEMS CURRENTLY IN OPERATION}

Currently there are literally thousands of custom PV systems operating in the U.S. Many of the smaller scale systems have been funded through the Federal Photovoltaic Utilization Program, FPUP, (see Table 5.1). The purpose of this program has been to develop the PV technology by establishing demonstration sites that will provide performance information to help direct future R\&D efforts.

Other experiments have installed medium and large scale custom systems (see Table 5.2).

The following are a brief description of a few custom systems:

- Solar-powered Warning Lights for

Transmission Towers

Bonneville Power Administration Washington, Oregon and Idaho.

The Department of Energy and Bonneville Power Administration (BPA) have installed PV warning lights on several transmission towers in Washington, Oregon, and Idaho using Solarex PV arrays. A battery storage system with a capacity of 5000 amperehours is also used. This is a more cost-effective system than other approaches. BPA has installed an ampere-hour monitoring device to see if the size of the present system could be reduced.

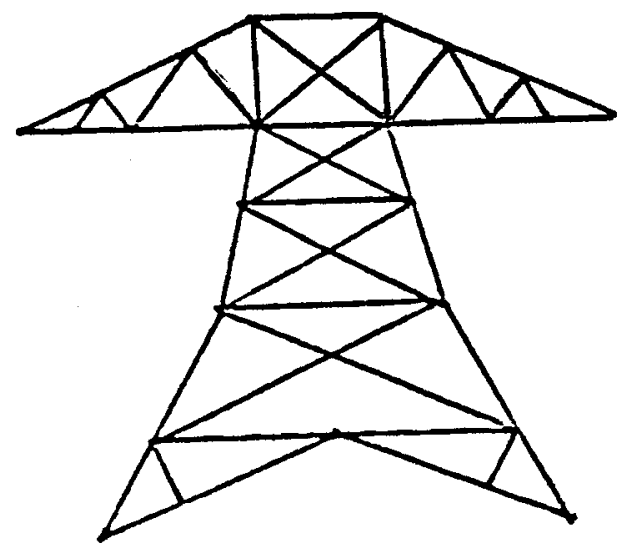


TABLE 5.1 Small Sized Custom Systems Funded Through FPUP

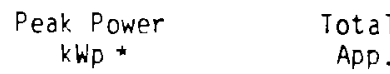

\begin{tabular}{|c|c|c|}
\hline $\begin{array}{l}\text { Residential Sector } \\
\text { Grid-connected Homes } \\
\text { Individual Homes } \\
\text { Other Residences } \\
\text { Water Pumps }\end{array}$ & $\begin{array}{l}2-20 \\
1-25 \\
0.1-8.5 \\
0.2-10\end{array}$ & $\begin{array}{r}2 \\
232 \\
22 \\
43\end{array}$ \\
\hline $\begin{array}{l}\text { Commercial Sector } \\
\text { Radiation Samplers } \\
\text { Visibility Monitors } \\
\text { Noise Monitors } \\
\text { Navigational Beacons } \\
\text { Weather Monitors } \\
\text { Particulate Sensors } \\
\text { Meteorological Sensors } \\
\text { Military Ammunition Security } \\
\text { Electric Fence } \\
\text { Intrusion Detectors } \\
\text { Cathodic Protection } \\
\text { Pwr Line Towers } \\
\text { Submarine Cables }\end{array}$ & $\begin{array}{l}0.04-3 \\
1.5 \\
0.01 \\
<1 \\
<1 \\
0.04-10.5 \\
<1 \\
<1\end{array}$ & $\begin{array}{r}30 \\
6 \\
2 \\
18 \\
4 \\
26 \\
325 \\
122 \\
1 \\
6 \\
12 \\
12\end{array}$ \\
\hline $\begin{array}{l}\text { Transportation Sector } \\
\text { Beacons } \\
\text { Buoys } \\
\text { Anemometer } \\
\text { Moving Target Indicators } \\
\text { Radar Beacons } \\
\text { Aircraft Arresting Systems } \\
\text { Astronomical Monitor } \\
\text { Flash Beacons } \\
\text { Remote Instrument Platforms } \\
\text { Starpex Beacon }\end{array}$ & $\begin{array}{l}<0.02-3 \\
<0.05 \\
0.004 \\
1 \\
<1 \\
<1 \\
<0.5 \\
0.1-1.5 \\
0.5-9 \\
<i\end{array}$ & $\begin{array}{r}1,427 \\
3 \\
1 \\
41 \\
9 \\
2 \\
1 \\
12 \\
33 \\
1\end{array}$ \\
\hline $\begin{array}{l}\text { Agricultural Sector } \\
\text { Forest Lookout Towers } \\
\text { Repeaters, Special Purpose } \\
\text { Venting Sys., Sanitation } \\
\text { Miscelianeous }\end{array}$ & $\begin{array}{l}<1 \\
0.01-1.2 \\
<1 \\
0.2-25 \\
\end{array}$ & $\begin{array}{r}67 \\
35 \\
248 \\
29 \\
\end{array}$ \\
\hline & TOTAL & 2,772 \\
\hline
\end{tabular}

* Where large numbers are installed, the lower figure is more representative.
TABLE 5.2. Intermediate Size Custom Systems

Wilcox Hospital/Acurex,

$35 \mathrm{kh}$

Kauai, Hawa i

Sky Harbor Airport/

Arizona Public Service,

Phoenix, Arizona

BDM Corporation,

Albuquerque, New Mexico

E Systems,

Dallas, Texas

Lovington Shopping Center/

Lea Country Electric,

Lovington, New Mexico

El Paso Electric/

New Mexico State University

El Paso, Texas

Oklahoma Center for Science and Arts/Science Applications, Inc., Ok lahoma City, Ok lahoma

Beverly High School/Solar Power

Beverly, Massachusetts

San Bernardino Concrete Plant

San Bernardino, California

$50 \mathrm{~kW}$

$27 \mathrm{~kW}$

WBNO Radio Station

Bryan, Ohio

Irrigation \& Crop Drying

Mead, Nebraska

$100 \mathrm{~kW}$

$17 \mathrm{~kW}$

$135 \mathrm{~kW}$

Air Force Station

Ft. Belvoir, Virginia

College Power System

Mississippi Country Community College

Blythesville, Arkansas

N.W. Mississippi Junior College

Senatobia, Mississippi

$100 \mathrm{~kW}$

Remote Stand Alone Power System Natura? Bridges Nationa? Monument

$100 \mathrm{~kW}$

Blanding, Utah 


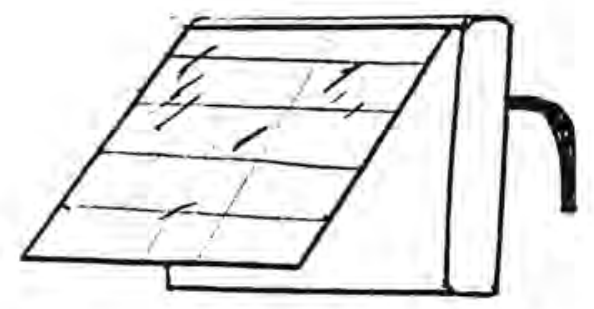

- Solar-powered Back Pack

Environmental Protection Agency

The Environmental Protection Agency developed a PV powered backpack unit as a power supply for various types of remote instrumentation. The unit uses a Solarex PV panel that can provide up to $120 \mathrm{~W}$. More power can be supplied by interconnecting units. Such a unit could easily be used for other remote applications.

- Solar-powered Indian Village

Papago Indian Village of Schuchuli

in Southwestern Arizona

Since 1978, the 15 families of the Papago Indian Village of Schuchuli have had their power needs met by a PV system. The $3.5-\mathrm{kW}$ system provides electricity for a water pump, refrigerators, clothes washer, sewing machine and fluorescent lights. In all cases, energy efficient appliances were chosen.
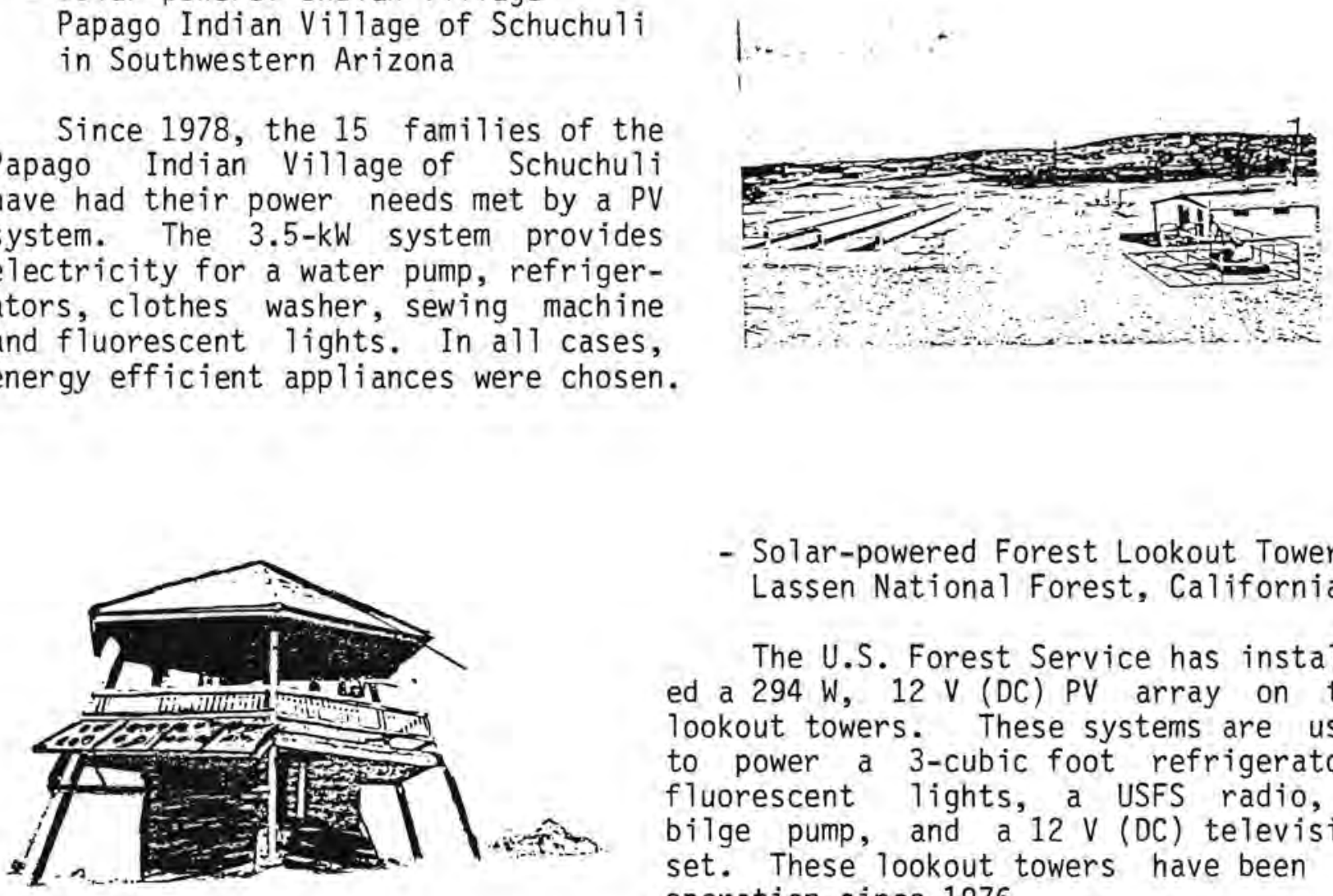

- Solar-powered Forest Lookout Towers Lassen National Forest, California

The U.S. Forest Service has installed a $294 \mathrm{~W}, 12 \mathrm{~V}$ (DC) PV array on two lookout towers. These systems are used to power a 3-cubic foot refrigerator, fluorescent lights, a USFS radio, a bilge pump, and a $12 \mathrm{~V}$ (DC) television set. These lookout towers have been in operation since 1976 .

\subsection{CUSTOM COMPONENTS AND SYSTEMS}

Most individual's energy needs will be met with components or systems already designed and built of similar applications. It may take a little time and a few telephone calls, but the chances are, your unique energy need is not unique. You may find that a PV firm designed and built a custom system a few 
years ago for someone else's unique energy need, and that this firm now offers this system on special order. However, if your energy need can not be met with off-the-shelf or special order systems, many companies within the PV industry will be willing to design and build a custom system. Remember, the design services provided by PV firms are usually not free, and you will be paying more (at least initially) for the custom built system than you would for an off-theshelf system.

Ask for a cost estimate before any work is done. Then, seriously consider the tradeoffs involved in having a custom system designed and built. Remember, it does pay to shop around!

The following PV companies indicated that they will either design and build custom systems or have systems that can be special ordered (see Table 5.3). 
TABLE 5.3. Firms Offering Custom Built or Specialty Components or Systems

\begin{tabular}{|c|c|}
\hline Company & Custom Component/System \\
\hline AAI Corp. & Modules \\
\hline Abacus & $D C$ to $D C$ converters \\
\hline Acurex Solar & Concentrating collectors \\
\hline ARTU & $A C$ Power systems and special $D C$ to $A C$ inverters \\
\hline Applied Solar Energy Corp. & Concentrating collectors \\
\hline A. Y. McDonald & Water Pumping systems \\
\hline Jim Cullen & System design \\
\hline Roger R. Ethier Assoc. & System design \\
\hline Free Energy Systems & $\begin{array}{l}\text { PV modules and refrigeration, lighting, and } \\
\text { comunications systems }\end{array}$ \\
\hline Genera 1 Electric & Modules and systems \\
\hline Globe & Batteries and hardware \\
\hline Helionetics & Inverters \\
\hline IOTA Engineering & DC ballasts \\
\hline March Manuf acturing & Pumps \\
\hline Milton Rov Company & Pumps \\
\hline Mobil Tyco & Systems \\
\hline Motorola & Power systems \\
\hline Parker McCrory & Panels \\
\hline Photon Power & Arrays \\
\hline $\begin{array}{l}\text { Photovoltaic Energy } \\
\text { Systems, Inc. }\end{array}$ & Consulting \& energy information products \\
\hline Silicon Sensors, Inc. & Arrays \\
\hline Solar Contractor's, Inc. & PV systems \\
\hline Solar Power Corp. & PV systems \\
\hline Sol arex & General applications assistance \\
\hline Solarwest Electric & $A C$ and $D C$ power packages \\
\hline Solar Energy Corp. & Modules \\
\hline Solar Usage Now & Remote water pumping systems \\
\hline Solenergy Corp. & Modules, arrays, PV systems, cells \\
\hline Spire & PV process equipment, assembling PV modules \\
\hline Teledyne Inet & Inverters \\
\hline Tidel and Signal & DC power packages \\
\hline Tri Solar Corporation & Irrigtion systems, home electric systems \\
\hline United Energy Corp. & Modules and systems \\
\hline Western Solar Refrigeration & $\begin{array}{l}\text { Ice maker, produce cooler, fish freezer, potable } \\
\text { water pump }\end{array}$ \\
\hline Windworks & Power conditioning equipment \\
\hline Zomeworks & Passive solar trackers \\
\hline
\end{tabular}




\subsection{WHEN TO CHOOSE PV}

The purpose of this chapter is to offer guidance to you in deciding when to select PV powered systems. There are several types of applications where PV has carved out a clear niche and some others where PV doesn't make sense yet. There also is one other type of situation where the wise decision balances on the uniqueness of the location and/or on your individual needs. This latter case generates a more difficult decision for you to make and thus, it will receive a greater emphasis in this chapter.

PV systems are not yet cost-effective where people live near or on a utility grid and wish to continue in a normal lifestyle using a substantial amount of electrical power without any serious effort to adjust their electricity use level. Since the concept of a large roof top array generating electricity for domestic needs with some extra to sell to the utility is an exciting vision, there is a substantial program involving private and government funding to someday make it a reality. Although many believe it may soon become practicable, right now the cost of a PV system to do this job would cost about $\$ 150,000$ per home.

In instances where individuals are willing to accomodate reductions in energy requirements, currently available PV systems may be a viable energy resource. This is especially true if a premium is placed upon the unique benefits of PV systems such as reliability, security, self-sufficiency, environmental compatibility, modularity, and privacy. For those considering building a vacation or retirement home in a remote area, photovoltaic power supplies are well worth serious consideration. For farmers or outdoorsmen, the portability and freedom from utility hook-ups of PV powered systems make them valuable for applications from lighting, to water pumping, to security systems.

There are a growing number of applications where PV systems are clearly preferable to alternative power sources. This is the case where remote power requirements must be met where no utility power is conveniently available for such applications as communications repeaters, navigational aids, and remote sensing equipment. In some instances, the cost of connecting equipment to locally available utility supply may exceed the cost of PV power supplies, a 
case in point is the frequent use of PV power supplies for aircraft warning lights atop high tension electrical transmission towers. PV systems are also clearly appropriate in instances where power needs are uniquely coincident with solar insolation and the PV supply provides system control as well as power.

The identification of appropriate applications of PV technology requires an assessment of the cost and performance of PV powered systems relative to avai1able alternative systems. The term system is stressed because the optimal method of achieving a specific end may be met through various assemblies of equipment which may vary depending on the power source used. For instance, if water pumping is desired one may choose a mechanical system which directly uses wind to provide pumping, or one may select a PV system which converts sunlight into electricity and then uses electricity to provide pumping.

In the discussions which follow we compare the performance of PV systems with appropriate alternative systems where it has particular advantage. The alternatives to be considered include:

- utility power available from the power grid

- wind power for water pumping or electricity generation

- gasoline or diesel generators for electricity

- manual labor

The cost effective application of any of these power supplies necessitates appropriate levels of energy efficiency. The optimal system to fit your needs may be a hybrid which uses two or more of the above energy supplies along with energy conservation principles. Section 6.1 presents applications where currently available PV systems clearly make sense and Section 6.2 discusses instances where PV may be the best power source depending upon your specific needs.

\subsection{WHERE PV CLEARLY MAKES SENSE}

Photovoltaic energy systems are being employed in a growing number of applications where utility power is either not available or relatively expensive to access. We say relatively expensive, because in some applications the cost of 
installing a PV powered system is cheaper than connecting a conventional appliance to the utility supply. The applications where PV clearly makes sense can be classified into three categories:

where power is needed in remote or difficult to access areas

- where net installation costs are lower

- where there is a unique timing of needs

The following discussions highlight examples of these applications and discuss the benefits of PV applications relative to alternative measures.

\subsubsection{PV for Remote Areas}

PV systems have demonstrated cost-effectiveness in industrial applications away from utility grids where average power requirements are less than one kilowatt. More than 10,000 remote PV applications are installed to power warning beacons on oil drilling platforms, power telephones and repeater stations, radio transmitters on mountain tops as well as for many other applications. These applications have demonstrated superior economics and reliability. Initially these applications were for power requirements in the range of only a few watts per installation. However, with the increasing cost of fossil fuels, and the availability of larger PV systems, larger electrical loads are using PV supplies.

Each instaliation has unique features to consider in the selection of the best power source. A few of the key attributes of PV power systems are:

1. Reliability - Properiy sized PV systems demonstrate excellent reliability in very hostile environments. The costs of failures should be considered.

2. High Altitude Performance $P V$ is favored at high altitudes because the air is thinner and the sun is brighter. For example, at high altitudes a typical diesel generator must be derated to perhaps $1 / 2$ of sea level capacity with consequent losses in efficiency as we11 as capacity.

3. Maintenance Cost - Transportation of materials and qualified personnel to remote areas for periodic maintenance is very expensive. Since PV systems require only periodic inspection and occasional replacement of storage batteries, maintenance costs are usually much less when compared to alternatives. 
4. Cost of Fuel - Procurement, storage, and transportation costs of fuel are foregone with PV energy supplies.

Since most remote industrial applications have firm or essential power requirements only those power sources which can perform on a consistent bas is are acceptable. Consequently, alternative energy sources such as wind or hydro are seldom acceptable alone. However, some hybrid systems are currently in application that combine the reliability of a PV system with the economy of a wind generator. Typically, the wind power is used for optional or intermittent loads while the PV system assures a minimum level of power availability for essential needs.

For power needs in excess of 1 killowatt continuous, the major alternative in application is diesel for LP gas powered generators. Although diesel systems have relatively low first (purchase) costs, the cost and availability of fuel in remote areas is of such significance that PV arrays are becoming the preferred power source for applications of up to 10 kilowatts. The economics and reliability uncertainties of diesel equipment relative to the security of PV systems are primary influences increasing the use of PV power sources.

In addition to the energy needs for remote industrial equipment, there are significant opportunities for less remote agricultural, residential, and recreational application. A survey of several electric utilities has indicated that the cost for utility line extensions averages over $\$ 10,000$ per mile. The cost and accesibility of such extensions will vary according to the servicing utility, and the cost will more likely be higher than lower. If soil conditions are less than ideal or if right of way for the power lines must be secured, the costs can rise precipitously.

As a consequence, PV supply systems should definitely be considered where utility connection costs are significant. Rather than putting ones money into power lines that must be paid for in addition to the ever increasing price of the power delivered, one can invest in a PV system that has higher reliability and lower operating cost. The farmer who needs to pump water for his livestock may best be served by a PV system that pumps water in relation to the intensity of sunlight. Historically, wind systems have been utilized for this application, and where sufficient wind is available for year round needs it is usually 
the cheapest alternative. However, in those instances where wind systems have been found to be less than completely sufficient, adding a PV powered pump for a hybrid system may be ideal.

Another example of a remote application would be a vacation home in the wilderness. The alternative sources of power available include, wind power if sufficiently reliable, hydro power if sufficient and legally useable, a gasoline or diesel generator set if cost effective and environmentally acceptable, or a silent, reliable, and cost-effective PV system. Once again, if conditions permit, a hybrid system may be the best approach, where in one can combine the reliability of a PV system, with potential economies of alternatives. One of the great benefits of hybrid systems where battery storage is necessary, is that several types of electrical generation can utilize the battery storage to its fullest extent at low incremental cost.

\subsubsection{Where Net Installation Costs are Lower}

PV clearly makes sense in the case of low power needs. Although utility power may be available, local costs for wiring are sometimes sufficient to justify the cost of a PV panel. Retrofitting an attic fan or driveway light can be expensive, however a PV attic fan can be easily installed by the handyman without shock hazard. It is extremely expensive to run a conduit up the side of a petroleum tank to supply a level indicator or a light. It may be more cost efficient to use a small PV array close to the power need for installations such as this.

To assist the reader compare the costs of using a PV system to supply power where connection costs to utility power are significant we have tabulated typical costs for cormon wiring tasks in Table 6.1. Actual costs for your installation will vary depending upon the local costs and availability of materials and skilled labor. Although many jobs can be undertaken by "handyman" types, the use of licensed electricians is advisable due to the liability risks of safety hazards resulting from improper appliance installation. 
TABLE 6.1. Typical Local Costs of Supplying Remote Branch Circuits

\begin{tabular}{|c|c|c|}
\hline Cost Item & Example $\mathrm{Ft}$. & $\begin{array}{l}\text { Total Cost } \\
\text { of Wiring }\end{array}$ \\
\hline $\begin{array}{l}\text { Cost of controls and wiring } \\
120 \text { vac attic fan }\end{array}$ & $75^{\prime}$ of Romex & 123.48 \\
\hline $\begin{array}{l}\text { Same except use } 1 / 2 " \text { st'l } \\
\text { conduit }\end{array}$ & $75^{\prime}$ of Conduit & 160.14 \\
\hline $\begin{array}{l}\text { Cost of wiring \& installing } \\
\text { a driveway light }\end{array}$ & $100 '$ Conduit & 259.56 \\
\hline $\begin{array}{l}\text { Cost of wiring and connect- } \\
\text { ing auto. gate opener on a } \\
\text { ranch }\end{array}$ & 500 ' Conduit & 877.80 \\
\hline $\begin{array}{l}\text { Cost of wiring a stock } \\
\text { watering pump. } 1 / 4 \mathrm{HP} 230 \mathrm{~V}\end{array}$ & $\begin{array}{l}1500^{\prime} \text { of } \# 83 \\
\text { Conductor Cable }\end{array}$ & $\$ 2,271.36$ \\
\hline $\begin{array}{l}\text { Cost of supplying power to } \\
\text { a level indicator on petro- } \\
\text { leum storage tanks }\end{array}$ & $\begin{array}{l}500^{\prime} \text { to tank, } 75^{\prime} \\
\text { vertical run up } \\
\text { tank, } 20^{\prime} \text { hori- } \\
\text { zontal all in } \\
\text { Conduit }\end{array}$ & $\begin{array}{l}\text { about } \\
\$ 5,000\end{array}$ \\
\hline
\end{tabular}

\subsubsection{Unique Timing of Needs}

PV power supplies also clearly make sense when the energy needs are proportional to the sun intensity. Such conditions exist in many heating or cooling applications. One example is water circulation pumps in solar heating systems. A circulating pump connected to a PV panel will circulate the water at a rate proportional to the rate of hot water production. It will circulate fastest when the sun is at its hottest.

In such applications, PV offsets the cost of controls normally used and is generally more reliable. The benefits of PV as motive power for solar collection systems include: a) improved reliability, b) improved system efficiency because of proportional control, c) improved protection against freezing because water is not pumped until the sun warms the panel and, d) simplified installation and maintenance. These considerations often times outweigh initial cost differences between PV powered and standard controls.

Another example is powering an evaporative cooler with PV panels. In the hottest weather, the sun shines much more than the yearly average, and the PV 
array produces additional power for the cooling unit. Since demands on utilities are often the greatest during the hottest periods, a growing number of them are adopting pricing systems which charge more for power during these hours. Under these conditions PV powered coolers will have improved cost effectiveness.

The sun-synchronous watering needs of livestock and agricultural areas offer unique opportunities for PV power supplies. Here again, the need for pumping typically occurs when the sun shines the hottest. A PV system is particularly suited to such requirements, and because water storage can replace the need for electrical storage in batteries, system purchase and upkeep costs are minimized.

The key factor in these types of applications is timing. If energy needs are coincident with the solar intensity, PV systems have inherent benefits which often make them the least expensive and most practical form of energy supply. Since these applications use power as it is generated, electrical storage systems are typically unnecessary. Therefore, these systems are among the simplest, most easily maintained, and most cost-effective PV applications currently available.

\subsection{WHERE PV MAY MAKE SENSE}

There is an endless variety of applications where PV may be the most sensible power source depending upon the specific concerns, needs, and preferences of the purchaser. As mentioned in the introduction to this chapter, many of these factors can only be assessed and valuated by the individual making the purchasing decision. The purpose of this section is to suggest some applications where PV offers particular advantages which may be of value to you.

Although dollar cost is an important, often the most important, item in selecting power supplies many other factors may influence the decision. These include impacts on the environment, the national economy, world security, and feelings of personal well being from self-sufficiency, to name a few. Given the uncertainties regarding the cost and availability of future energy supplies and the stability of the world economy, many of you may place a premium on the certainty a PV energy supply can provide. The fact that PV systems are silent 
and otherwise environmentally innocuous, simple and easy to maintain, reliable and essentially free of inflationary pressures, may make them attractive at present prices.

Surveys indicate that more people than ever are concerned about our energy future. Since 1975, a significant change has occurred in the way people look at the energy question. According to a recent study (Sumichrast, December 1980, published by National Association of Home Builders), $80 \%$ of home purchasers in 1980 considered energy a serious problem whereas in 1975, only about $25 \%$ considered energy a problem. Only 7\% rated the energy problem in 1975 "extremely serious" but this has increased to about $36 \%$ by 1980 and is indicated to increase to about $74 \%$ by 1985. Consequent1y, a growing number of people are finding that it may be acceptable and even advantageous to reduce their energy dependence through conservation, lifestyle changes, and/or utilization of renewable energy resources.

Clearly there are a large number of people today who are concerned about the future supply and cost of energy. Building a dream home could become a nightmare if utility bills (heating and electrical) aren't controlled. Consequently interest in energy efficient homes and passive solar designs has escalated dramatically in recent years, but surprisingly little attention has been given to the possibility of markedly reducing electrical consumption in the home. If significant reductions in electricity requirements can be accomodated as suggested later in this chapter, PV power systems may prove to be an appropriate and affordable power supply.

Will people continue to buy homes which face an uncertain future of higher fuel bills? Most believe that they will if actions are taken to minimize the cost of energy supplies. This is done first by reducing energy needs through conservation features and lifestyle adjustments, and then procuring dependable and economic fuels. Photovoltaics is the most desireable power supply in many instances today, and as the cost of alternative systems increase, the number of cost effective applications is expected to grow dramatically.

The fact is that the cost of energy from the PV array over its reasonably expectable 25 year life is constant, and even reduces in real cost compared to the other commodities required for living. The cost of electricity for most 
utility companies will increase at a rate significantly higher than inflation. On the other hand if a PV system is purchased as part of a 30 year home mortgage, the real burden of those fixed payments typically diminishes as time goes by. If a purchaser's income increases as inflation mounts, and the house payment remains constant, it constitutes a diminishing percentage of total income. The cash flow economics will depend upon your particular perspectives and locale, but it is an important consideration for those nearing retirement, or particularly concerned about their future income potential.

Businesses and residences located in remote areas away from power lines can benefit from PV. Factors to consider in these situations are: a) connection costs, b) costs of extending a power line to your property, and c) advantages of avoiding monthly power bills. If a decision has been made to settle or start a business enterprise where utility power is not readily available, PV may be your best alternative. You must consider the costs to run a utility line out to your property (typically in excess of $\$ 10,000$ per mile), the cost of metering and connection, and finally the cost of the power bills.

If a PV system is to be employed to power a building, extensive measures should be taken to reduce the energy needs of the structure. As in other solar systems, it simply does not make sense to use relatively expensive collectors to replace energy which could be more cheaply conserved. The economics of conservation and PV power supplies is dependent upon conditions at the building site such as climate and energy costs. Although, we cannot offer specific guidance for particular applications, we discuss below some example residential installations which reveal the impact of energy conservation and lifestyle adjustments on the size and cost of suitable PV electricity supply systems.

We have conducted the analysis using climatic data for Phoenix, Arizona. The reasons for selecting this location include:

1. The amount of solar insolation (sunshine) is among the highest in the country.

2. The predominant electricity requirement is for space cooling, which is largely coincident with the availability of PV power. 
3. The cost of grid supplied electricity is among the highest in the nation.

4. Population growth statistics indicate a continued high rate of home construction.

5. Sufficiently accurate and detailed climatic information is available to utilize sophisticated energy analys is tools.

Consequently, these examples may represent a "best case" for photovoltaic deployment in the residential sector using currently available PV technonogy.

The analysis consists of four cases conducted in two distinct parts. For the first three cases, we assume that only physical alterations in the design and appliances of the home are made without significant change in the use of the home. Then we suggest a case where significant adjustment in lifestyle is made to minimize the cost and maximize the effectiveness of the photovoltaic energy supply system.

In each case a living area of 1,400 square feet has been accomodated, although the design and construction of the home may be significantly altered. The energy supply is sized to meet the typical needs of the average family of three for the first part of the analysis, and is affected only by improvements in appliance efficiency and energy conservation measures. Only the last case assumes that the occupants significantly alter their energy use habits.

It has been assumed that the home is not connected to the utility grid and the PV system is sized to supply all the electricity necessary to:

- keep internal temperatures below 80 degrees $F 98 \%$ of the time

- maintain adequate illumination levels

- provide power for a refrigerator

- provide adequate power for commonly employed home appliances

Since some of the energy requirement occurs when the sun is not shining, an electrical storage system is required. The cost of this storage requirement has not been rigorously calculated, but is included in the assumed PV system cost of $\$ 15$ per peak watt. At current costs of $\$ 10$ per peak watt for PV arrays and $\$ 100$ per Kwh of battery storage, this system cost provides for $20 \%$ of power use during non-sunlight periods. 
Fue 1 for cooking, as well as backup for space heating is assumed to be supplied by other means such as LPG, wood, or gasoline powered electric generators. However, a very significant portion of these needs can be met by the PV power supply when excess power is available, particularly if appropriate appliances are selected. Water heating is assumed to be supplied by either electrical or solar energy for the sake of consistency, although a fossil fueled water heater or back-up system would probably be more cost effective considering current PV system and fossil fuel prices. Additional groundrules of the energy use comparisons are listed in Table 6.2.

The energy required for space heating and cooling is dependent upon the characteristics of the building, the comfort requirements of the occupants, and the building climate. In order to calculate these requirements, we have utilized the DOE 2.1 computer program developed by the Department of Energy. The program uses information about the construction and use of the building in conjuction with weather data for each hour of the typical meterological year, to generate estimates of energy needs. The program has been validated against actual building performance in several studies, and has been found to yield estimates within about plus or minus $10 \%$.

In instances where the PV system is the primary source of home electricity, a back-up fossil fueled generator is very useful to provide additional power when extraordinarily low levels of sun, and high levels of need concur. For example, you may occasionally have a large number of overnight visitors increasing energy needs dramatically. It would probably not be cost effective to size the PV array for such short periods of higher than normal need, when a relatively inexpensive fossil fueled generator could be employed for short periods. The cost of this backup system has not been included however, since the need and value of it vary significantly depending upon the user.

\subsubsection{Case I -- Typical All Electric Home}

So as to minimize the cost of new homes, energy conservation features are often installed only to the level required by current building codes. Typically, the code is based upon historical rather than projected fuel costs, and 
TABLE 6.2. Groundrules of Energy Use Consumption

\author{
ARCHITECTURAL AND LIFE STYLE \\ CHANGES ON THE APPLICATION OF \\ 1981 PV TECHNOLOGY FOR RESIDENCES
}

\author{
PURPOSE \\ TO ASSESS THE TRADE-OFFS OF ENERGY EFFICIENCY. PV SYSTEM SIZE. AND LIFESTYLE \\ ADJUSTMENT

\section{MEASURES CONSIDERED} \\ INSULATION OF WALLS. CEILINGS. WINDOWS PASSIVE SOLAR, EARTH SHELTERING. WINDOW \\ GLAZINGS. AREAS. AND ORIENTATION. VAPOR BARAIERS. AIR TO AIR HEAT EXCHANGERS. \\ HEAT PUMP. SOLAR WATER HEATING. ENERGY EFFICIENT APPLIANCES AND LIGHTING

\section{METHODOLOGY} \\ COMPARE PV SYSTEM SIZE AND COST WITH CONVENTIONAL ENERGY COST FOR THREE LEVELS \\ OF ENERGY CONSERVATION HOLDING UTILIZATION AND AMENITY LEVEL CONSTANT AND ONE \\ ADDITIONAL CASE WHERE SOME LIFESTYLE AND COMFORT ADJUSTMENTS ARE MADE \\ ASSUMPTIONS \\ FAMILY SIZE \\ INTERNAL LOAD \\ INFILTRATION \\ PEAK SUN-HOURS \\ SOLAR HOT WATER FRACTION 80 \\ COOLING COP \\ ENERGY COST LEVILIZED \\ PV SYSTEM COST \\ TAX CREDITS \\ LDCATION \\ 3 \\ 53.100 Btu/day \\ COBLENTZ-ACHENBACH NORMALIZED \\ 80 \\ 3.0 \\ 8.1c/kWh \\ \$15/WATT \\ 40\% FEDERAL UP TO $\$ 4000.35 \%$ STATE UP TO $\$ 1000$ \\ PHOENIX
}


consequently the amount and cost of energy for heating and cooling is inordinately high. The ranch style home selected as representative of such construction is depicted and described in Table 6.3.

The typical peak electricity needs were found to be approximately $60 \mathrm{kwh}$ per day as shown. The major portion (67\%) is for summer cooling, and since solar water heating is not commonly employed, a full $10 \mathrm{kwh}$ per day is required for water heating unless alternative fuels are used. In order to meet the energy requirements a full $10 \mathrm{KW}$ of PV capacity is required which would cover nearly one half of the total roof area.

Even after utilizing the renewable energy tax credits to its fullest extent the cost of such a large system would be $\$ 125,000$, well above the realm of affordability by most of us. Thus there is some validity to the widespresd public perception that at least at present, photovoltaics are too expensive. However, as you read on, you may realize that this perception is not always justified.

\subsubsection{Case II - The Energy Efficient Home}

In recognition of the fact that energy costs are expected to continue to escalate as they have in the recent past, numerous buyers are demanding and builders are including additional energy conservation measures in new homes. By incorporating measures that cost no more than $\$ 1,375$ after tax credits the average peak energy requirement can be reduced by $40 \%$ to approximately $35 \mathrm{kwh}$ per day as shown in Table 6.4.

Items which reduce power consumption at significant additional cost include:

$\begin{array}{ll}0 & \text { thicker insulation } \\ 0 & \text { double glazed windows } \\ 0 & \text { complete vapor barrier } \\ 0 & \text { vestibule entry } \\ 0 & \text { use of efficient fluorescent lighting } \\ 0 & \text { solar water heating }\end{array}$

No cost features that have been incorporated include a two story design that reduces exposed surface area, and concentration of windows on the south facade that maximize solar heating in the winter while minimizing it in the summer.

6.13 


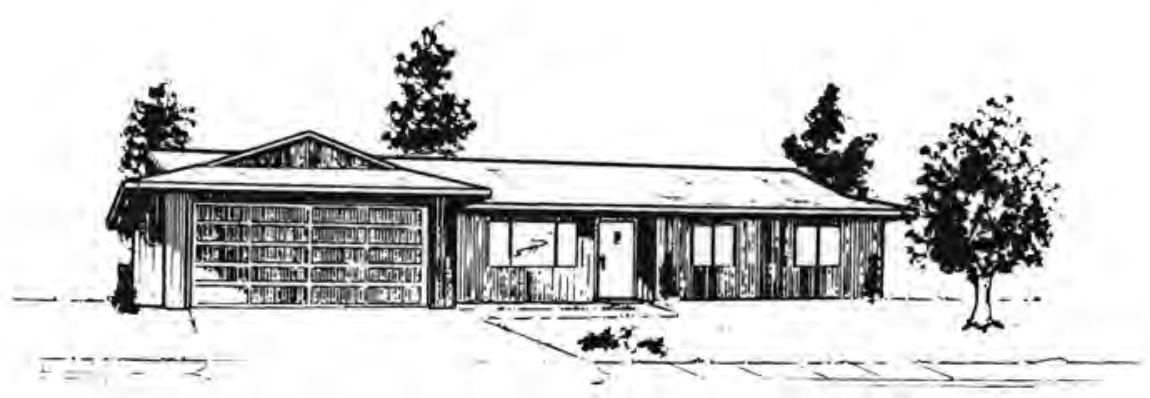

\section{CHARACTERISTICS}

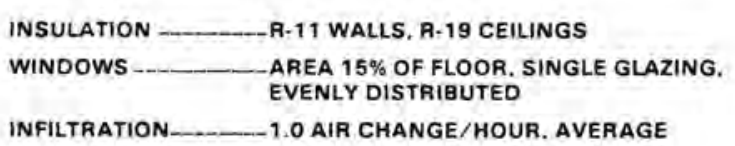

ELECTRICAL SYSTEM

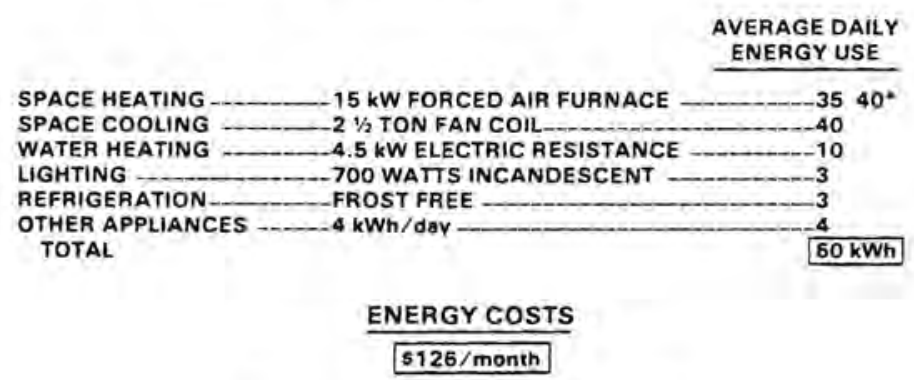

CONSERVATION MEASURE COSTS

50

PV SYSTEM SIZE AND COST

$60 / 6 \cdot 10 \mathrm{~kW} \rightarrow \$ 150.000$

NET SYSTEM COST

THE MAXIMUM TAX CREDIT WOULD BE $\$ 5.000 / y r$ FOR 5 YEARS (1981-1985)

OR $\$ 25,000 \rightarrow \$ 125,000$

'SUMMER DESIGN IS MORE SEVERE LOAD 


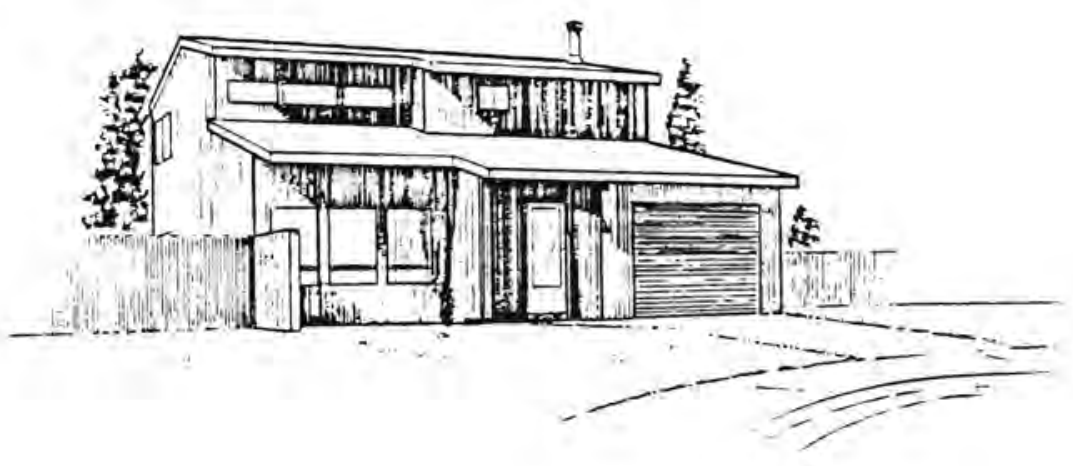

\section{CHARACTERISTICS}

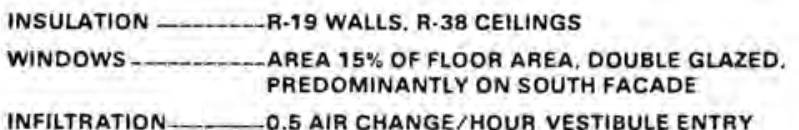

ELECTRICAL LOADS

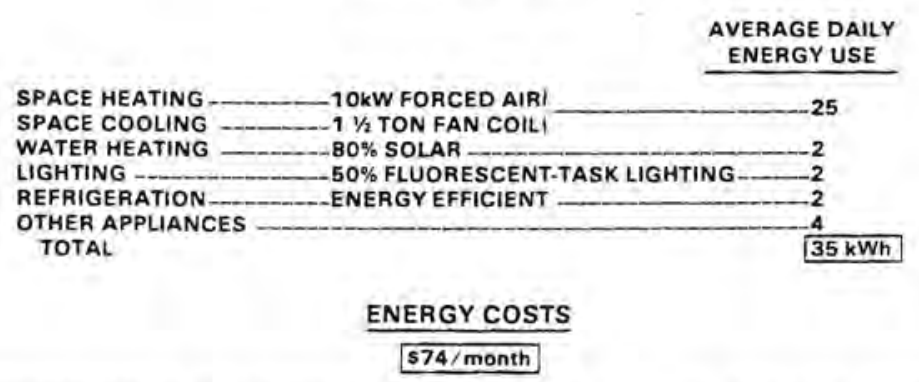

\section{CONSERVATION MEASURE COSTS}

INSULATION WINDOWS

VAPOR BARRIER

SOLAR HOT WATER

\section{CREDITS}

SYSTEM DOWNSIZING TAX CREDIT
PV SYSTEM SIZE AND COST

$35 / 6-5.8 \mathrm{~kW} \longrightarrow \$ 87.500$

\section{NET SYSTEMS COST}

$\$ 87.500$ LESS $\$ 25,000$ TAX CREDIT + $\$ 1365$ 563.865

NET

51365 
The cooling system required to condition this home is smaller than typical, and the electricity needs are reduced to $25 \mathrm{kwh}$ on the design day. Since solar water heating is employed which is adequate to meet $80 \%$ of the hot water needs, only 2 kwh per day of electricity are needed to heat hot water. The energy needed for the refrigerator by selecting a more energy efficient model at an insignificantly higher cost is reduced by one-third. Although the size of PV systems needed in this case has been reduced to $5.8 \mathrm{KW}$, the system cost after maximum use of tax credits would be $\$ 63,865$, still too expensive for most of us.

\subsubsection{The Earth Sheltered Home}

Many home buyers and builders are experimenting with unconventional construction techniques which offer the promise of dramatically reducing energy needs. The "earth-sheltered" home depicted in Table 6.5 is an example which has demonstrated that significant energy savings can be had, if what many consider to be radical architectural practices are acceptable. Earth sheltering reduces energy needs by using the earth as a buffer between the home and the surrounding environment thereby reducing both heating and cooling energy needs. In addition the installation of a continuous vapor barrier is simplified since earth sheltered walls are adequately sealed.

In addition to the features of the home described in Case II this home includes:

- Windows triple glazed and total window area reduced to $10 \%$ of floor area.

- Air infiltration has been reduced to a net of .1 air change/hour by using an air to air heat exchanger for ventilation.

This house uses about $1 / 2$ of the electrical energy of the "energy efficient" example largely due to the reduction on cooling energy requirements that results from earth sheltering and reduction of air infiltration.

The PV system size needed for this home is about $3 \mathrm{KW}$ which would fit nicely on the exposed roof lower level. A system of this size allows the tax credits to be used to their full advantage, covering more that $50 \%$ of the total system costs. Although the cost after tax credits is still some $\$ 21,125$, such a system may be affordable by some, especially when independence, privacy, or self sufficiency is desired. 


\section{TABLE 6.5. Earthsheltered Home}

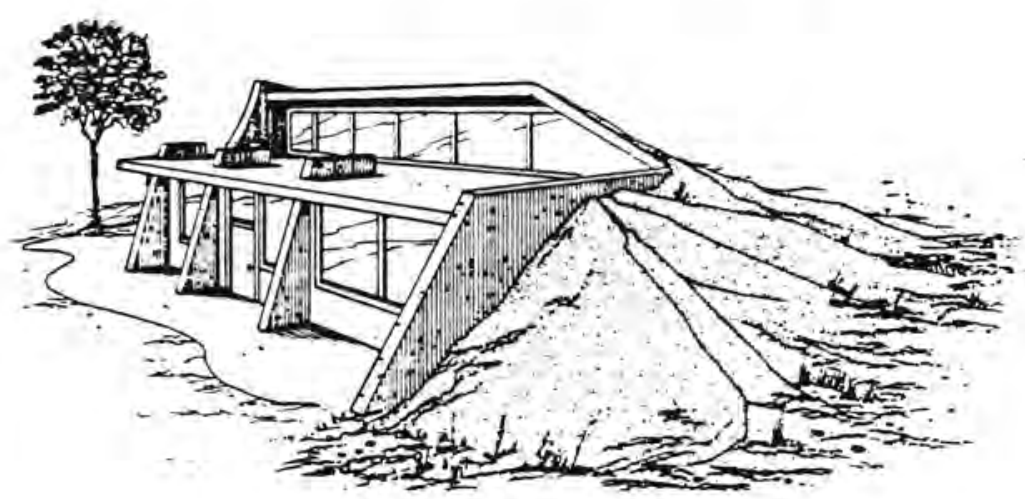

\section{CHARACTERISTICS}

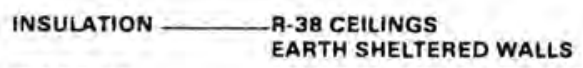

WINDOWS - TRIPLE GLAZED SOUTH FACING @ 10\% OFFLOR AREA OR SINGLE GLAZED WITH PHOTOELECTRIC MOVEABLE INSULATION

INFILTRATION_O 0.1 AIR CHANGE/HOUR NET 10.5 ACH. WITH $75 \%$ EFFICIENT HEAT EXCHANGE) VESTIBULE ENTRY

\section{ELECTRICAL LOADS}

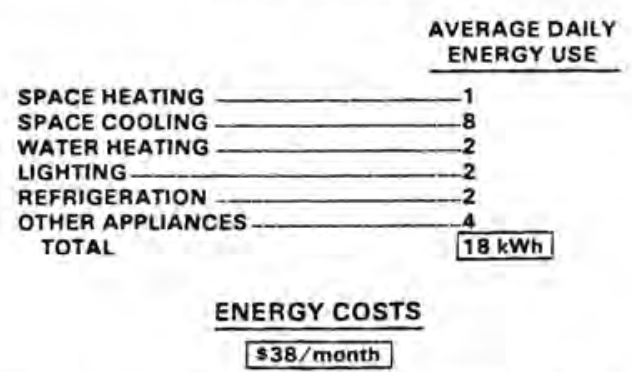

\section{CONSERVATION MEASURE COSTS}

EARTH BERMING

SOLAR HOT WATER

AIR-AIR HEAT EXCHANGER

CREDITS

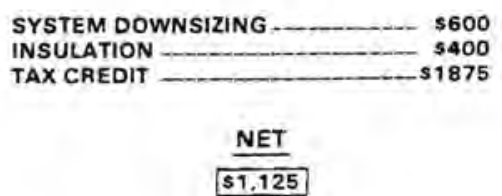

PV SYSTEM SIZE AND COST

$i 8 / 6-3 \mathrm{~kW} \rightarrow 545,000$

\section{NET SYSTEM COST}

$\$ 45.000$ LESS $\$ 25,000$ BY CREDIT $+1,125$ $\$ 27.125$ 


\subsubsection{Case IV -- The Energy Independent Home}

For some the desire for energy independence and protection from the uncertainties of our energy future may make significant lifestyle changes and energy use habits acceptable. It is for those who may be willing to implement such changes that we have prepared this example (Table 6.6). Because of the modular nature of PV energy systems, it is possible to start with a small system at first and add capacity as your needs dictate and finances allow.

It is possible to eliminate $90 \%$ of the electrical consumption of a typical home. Naturally, it raises the question of whether it would be pleasant to live in such a home. Judge for yourself. New types of lighting have been developed which give four times as much light per watt as an incandescent bulb. Refrigerators are available which are smaller than we are used to but operate on $1 / 4$ of the power a standard refrigerator uses. The list goes on.

In addition to the use of efficient appliances, you may consider curtailing unnecessary appliance use such as dishwashers, electric can openers, electric knives etc, and substituting manual methods. Of even greater potential impact is the proper scheduling of energy use activities so as to use power efficiently when it is available in abundance. For example cooking later in the evening reduces the load on the air conditioner, or washing with full loads only on sunny afternoons when solar heated water is available in abundance and PV power supply is great minimizes the size of battery storage.

Whether life could be fun with $90 \%$ reduction in electricity use is always debatable because for you it may be different than for your friend next door. If you could be happy with this kind of situation, you might be able to afford a new kind of pleasure derived from a move toward energy independence. If you could equip you new home with a PV power supply for about $\$ 10,000$, you would get substantial tax credit and wouldn't have to worry ever again about high electric utility bills ruining the enjoyment of your dream home. Is it a good economic investment? No one can give you the answer to that question because they don't know how high utility bills will go. How much is your peace of mind worth? No one else can decide that for you! It's up to you and no one else. 
TABLE 6.6. Energy Independent Home

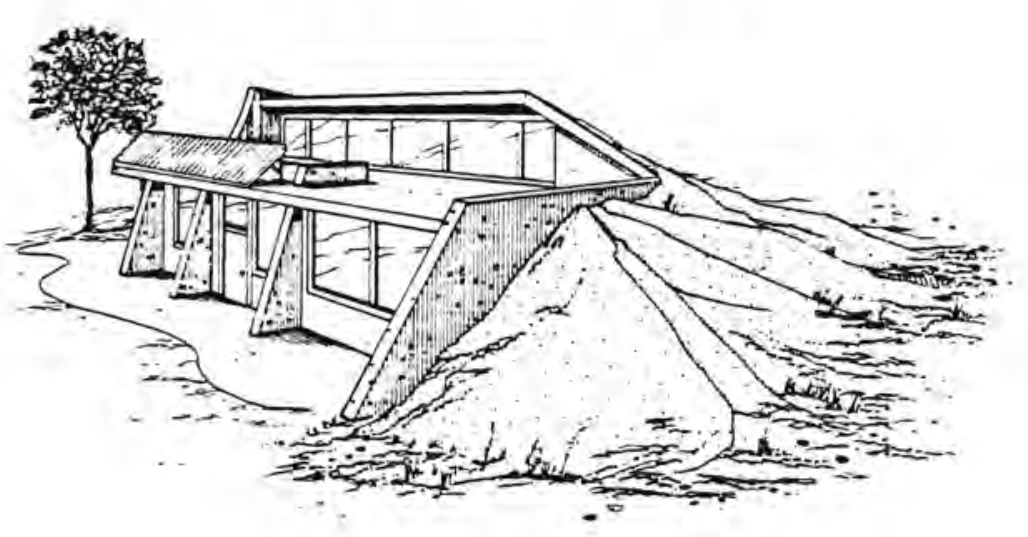

CHARACTERISTICS

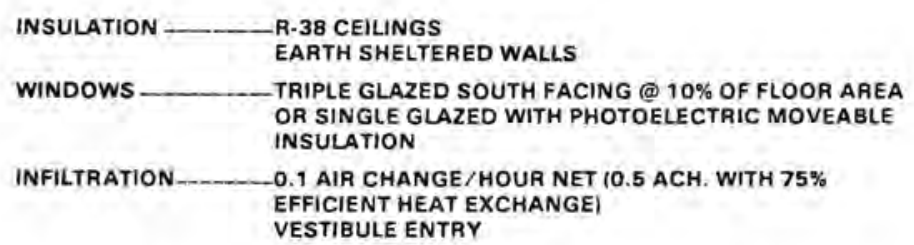

\section{ELECTRICAL LOADS}

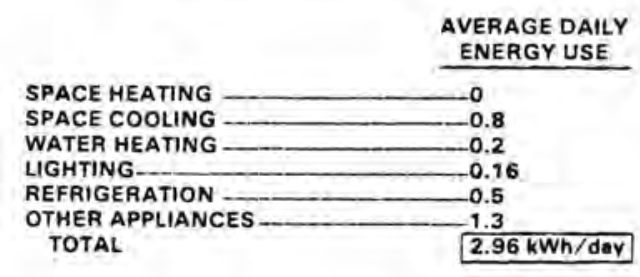

\section{ENERG COSTS}

s7/month

\section{CONSERVATION MEASURE COSTS}

EARTH BERMING ____ $\$ 1000$ SOLAR HOT WATER AIR-AIR HEAT EXCHANGER ___ $\$ 500$

\section{CREDITS}

SYSTEM DOWNSIZING _._______ $\$ 600$ INSULATION _ _ _ _ $\$ 400$ TAX CREDIT $-\$ 1875$

\section{NET}

\section{PV SYSTEM SIZE AND COST}

$2.96 / 6=0.4959485$

\section{NET SYSTEM COST}

$\$ 9485$ LESS 4794 BY CREDIT * 1125 EXTRA HOUSEHOLC. COST $=\$ 5816$ 
The house features and appearance is identical to the earth sheltered example, however the use and comfort level of the home are altered somewhat. Specifically this example assumes:

- Evaporative cooling alone is acceptable (the consequence of this assumption is that occasionally the home may be uncomfortably warm for some)

- Efficient fluorescent lights are used for only 8 fixture hrs per day.

- Energy efficient DC appliances are used

- Manual dishwashing and refrigerator defrosting are acceptable

- A smaller 4 cuft energy efficient refrigerator is used

- Back up for water heating is not provided electrically

The example used here is the same as that displayed in Chapter 4.0, Section 4.6.2. It will be recalled that some uses were curtailed. Energy for cooling will not be required at all times and this capacity is made available for other uses when possible.

The cooling load in summer is assumed to be supplied by two evaporative coolers operated by PV panels, power $0.8 \mathrm{Kwhr} /$ day. Hot water is supplied by solar panels with a PV powered circulating pump, power $0.2 \mathrm{Kwhr} /$ day. Lighting uses 12 V DC very high efficiency fluorescent lights and uses $0.16 \mathrm{Kwhr} /$ day. Refrigeration uses a small, high efficiency $12 \mathrm{~V}$ DC refrigerator, $0.5 \mathrm{Kwhr} /$ day. Other appliances uses total up to $1.3 \mathrm{Kwhr} /$ day for a total of $2.96 \mathrm{Kwhr} /$ day which is only 1/6 of the energy used in the earth sheltered home without energy management and lifestyle adjustment.

The starter system to provide for these requirements listed in Table 6.6 has a capacity of approximately .5 KW. This size PV system for the Phoenix area has a system cost of about $\$ 9,485$ using current prices. Tax incentives (Federal and State of Arizona) reduce the net PV cost to less than $\$ 5,000$. Adding to this the cost of the specified conservation measures of about $\$ 1,125$ brings the net concept cost of this residence to less than $\$ 6,000$. This is a very affordable level of expense. If the system was found to be restrictive of life style, it quite easy to install additional capacity in subsequent years. 
The concept may be too restrictive for permanent use but it appears liveable for the first year. You could add to this system in $\$ 10,000$ increments getting $\$ 5,000$ tax benefits each year so that the net cost is greatly reduced. In fact the main benefit of the energy independent concept is that it lets you get started with PV at a modest cost in such a way as to take maximum advantage of the Federal tax credits which are slated to expire in 1985.

\subsubsection{Summary of Case Studies}

A review of these four case studies is helpful to gain an appreciation of the impact of home energy requirements on photovoltaic system size and cost. Table 6.7 depicts each of the homes with a scaled drawing of the relative size of PV arrays to supply the calculated energy needs. As the annual and peak daily energy use diminishes, the size of the required array drops proportionally.

The typical all electric home consumes approximately 20,000 kwh per year, and requires $60 \mathrm{kwh}$ on the peak day, thereby necessitating a $10 \mathrm{KW}$ array costing about $\$ 125,000$ even after tax credits. Through the use of conventional conservation measures and passive solar design, the energy needs are reduced by approximate $1 y$ $45 \%$ so that only $11,700 \mathrm{kwh}$ per year are needed and the peak requirement is reduced to $35 \mathrm{kwh}$ per day, thereby making a $6 \mathrm{KW}$ array sufficient. Although the conservation features increase the cost of the home by $\$ 1,365$, the cost of the PV array required is reduced by $\$ 60,000$.

Clearly one would want to continue adding energy savings measures until their cost exceeds the savings to be had from downsizing the conditioning and photovoltaic systems. Utilization of earth sheltering principles can cut the energy needs of the energy efficient home again in half, requiring 6,000 kwh per year and only $18 \mathrm{kwh}$ on the peak day. Consequently a $3 \mathrm{KW}$ array is sufficient, costing $\$ 20,000$ after tax credits. Purchase of a system of this size over a 4 year period allows one to take maximum advantage of federal and state tax incentives, through the purchase of $\$ 10,000$ worth of arrays per year.

The prior three cases required only insignificant changes in lifestyle resulting soley from the incorporation of energy conservation features on the building and appliances. The final case, called the energy independent home 

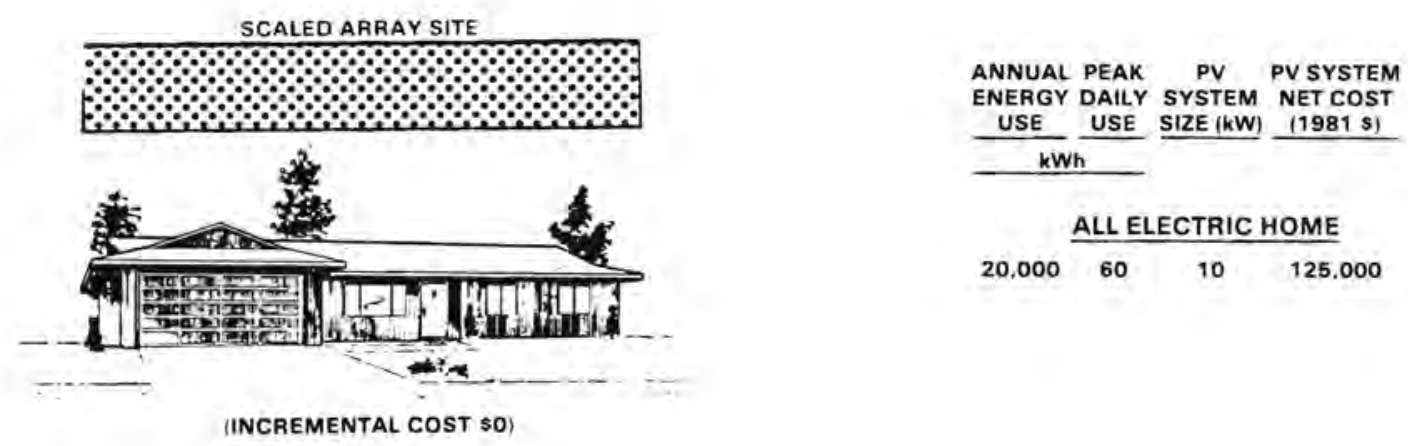

ENERGY EFFICIENCT HOME*

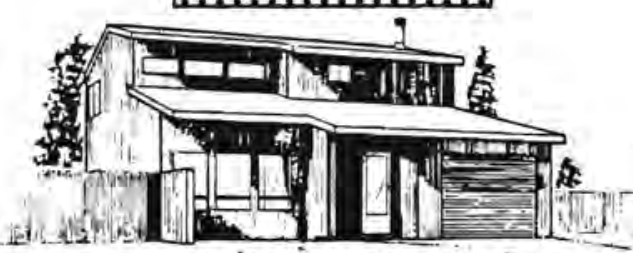

$\begin{array}{llll}11.700 & 35 & 6 & 65.000\end{array}$ (INCREMMENTAL COST \$1,325)
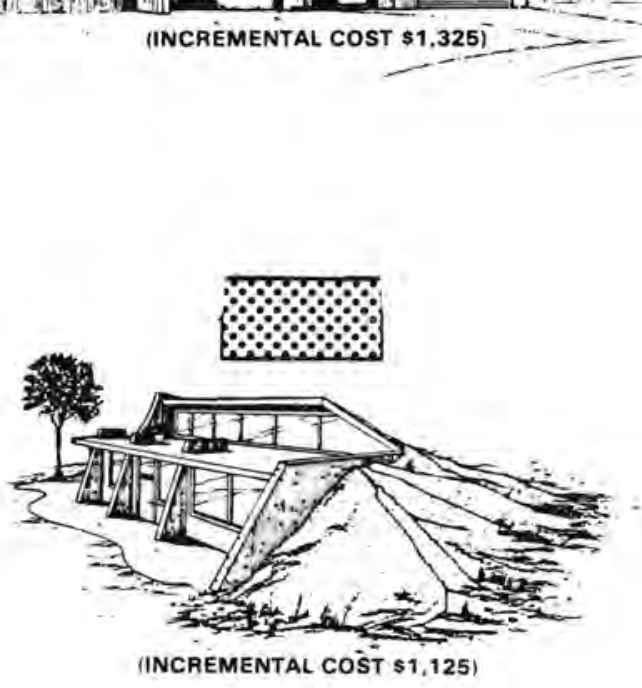

\section{EARTH SHELTERED HOME} $\begin{array}{lllll}6.000 & 18 & 3 & 20.000\end{array}$

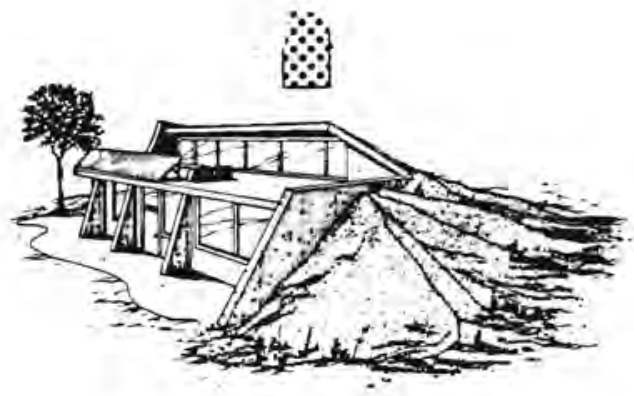

ENERGY INDEPENDENT HOME

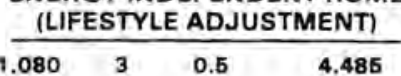

-NO LIFESTYLE OR COMFORT ADJUSTMENTS REQUIRED. 
concept, suggests that through prudent alterations in lifestyle to minimize energy needs and managing them in such a way that the effectiveness of the PV array is maximized, the size of the PV array can be drastically reduced. The energy needs of this home are approximatley $1000 \mathrm{kwh}$ per year and the peak daily load is limited to $3 \mathrm{kwh}$. A .5 KW array is sufficient to supply this level of energy need and would cost less than $\$ 5000$ after tax credits.

Tax advantages of purchasing larger systems should be considered in system selection, so as to maximize their cost-effectiveness. We present a summary of the federal and state tax credits in Appendix I for more information. We further recommend that you contact your state energy office for more comprehensive and specific guidance in taking advantage of available tax credits.

As mentioned previously the system size can be easily increased in subsequent years due to the modular nature of PV energy systems. Thus a system can be built over a period of years as your needs increase or your finances permit and tax credits will assist you at least until 1985. Since the future of tax credits is uncertain past this period, it is highly advisable to utilize them now while they are available.

In Table 6.8 we list some preliminary findings of this case study which you may want to take into account if you are considering the purchase of a home electric system. Although these findings are based upon weather data and tax credits of Phoenix Arizona, they are generally applicable to other areas, although optimal system size will likely be different. However by raising these issues with a local PV supplier, you will be well on your way towards the pruchase of the most cost effective system to meet your particular needs.

\subsection{PURCHASING A PV SYSTEM}

PV systems have been demonstrated to provide reliable and cost effective power supply in numerous instances. We have endeavored to highlight some of them in this directory and as this goes to press many more are emerging. Because of this rapid expansion of the types and sources of PV products reaching the marketplace, some words of advice to potential purchasers are warranted. 


\section{TABLE 6.8. Preliminary Findings}

THE EFFECTS OF ENERGY CONSERVATION APPROACHES ON THE ELECTRICITY REQUIREMENTS AND THE POTENTIAL FOR ELECTRICAL ENERGY INDEPENDENCE.

1. PV SYSTEMS ARE MOST COST EFFECTIVELY EMPLOYED ON MORE ENERGY EFFICIENT HOMES

2. UNDER CURRENT FEDERAL TAX REGULATIONS. ONE CAN CLAIM \$4000 ANNUALLY FOR THE PERIOD 1981.1985 RESULTING IN A MAXIMUM TAX BENEFIT OF $\$ 20,000$

3. UNDER ARIZONA STATE TAX REGULATIONS. ONE CAN CLAIM $\$ 1000$ ANNUALLY FOR THE PERIOD 1981-1985 RESULTING IN A MAXIMUM TAX BENEFIT OF $\$ 5000$. OTHER STATES HAVE DIFFERENT TAX \& INCENTIVE REGULATIONS. WHICH MAY APPLY

4. TAX BENEFIT \& CONSEQUENTIAL COST-EFFECTIVENESS IS MAXIMIZED BY MODULARLY BUILDING PV SYSTEMS IN $\$ 10.000$ INCREMENT ANNUALLY

5. CONSEQUENTLY. THE EARTH SHELTERED STYLE HOME WHICH REQUIRES $3 \mathrm{~kW}$ CAPACITY IS OPTIMAL FOR PV DEVELOPMENT WITHOUT CHANGE OF LIFESTYLE. THIS COULD BE APPROACHED WITH A GASOLINE GENERATOR PROGRESSIVELY REPLACED OVER THE PERIOD 1981-1985. PURCHASE OF 3/5kW PER YEAR FOR 5 YEARS

6. ASSUMING GRID EXTENSIONS COST $\$ 10.000$ MILE. THE EARTH SHELTERED BUILDING IS COST EFFECTIVE MORE THAN 1 MILE FROM THE GRID.

7. WITH APPROPRIATE LIFESTYLE ADJUSTMENT. NECESSARY RESIDENTIAL ELECTRICAL REQUIREMENTS CAN BE SATISFIED WITH A 1/2kW SYSTEM COSTING LESS THAN $\$ 5.000$ (AFTER TAX CREDITS). THIS SYSTEM CAN BE UPGRADED IN SUBSEQUENT YEARS. IF DESIRED. TAKING FULL ADVANTAGE OF TAX CREDITS 
Once you have identified a potential application for a PV energy system, contact several vendors to compare the products available. Take the time to explain your needs to the vendor and that you are contacting other suppliers to compare products, services, and warranties. You may want to ask for references to satisfied customers, or copies of product brochures and warranties. Most reputable vendors will have little trouble satisfying these requests.

If you anticipate taking advantage of tax credits available for renewable energy systems, contact your state energy office to get the details on their requirements and limitations. They may also maintain lists of licensed vendors or installers as well as individuals utilizing PV energy supplies. In addition, many communities have associations of individuals sharing information on solar energy and energy conservation to which the energy office can refer you for more information.

Industry and government have worked hard to bring this space age technology down to earth so it can be employed to meet our energy needs. The products are available, significant financial incentives are in place, and the risks of failure are very low. The key question for you to ponder is "Am I ready for photovoltaics", rather than "Are photovoltaics ready for me". We stand on the threshold of a secure energy future, and you now have the option to move through it by purchasing a photovoltaic energy system to supply your electrical needs, and set the example for millions to follow. 


\subsection{USER EXPERIENCES WITH PHOTOVOLTAICS}

In addition to reviewing the literature related to the design and performance of photovoltaic power systems, prospective PV purchasers can gain invaluable insight into PV performance from current users. This chapter describes a variety of installations and an appraisal of their performance by the owners. The discussions are based upon information received from personal interviews conducted by the authors.

The characteristics of the PV users interviewed are as diverse as the types of systems described. We interviewed young entrepeneurs, middle aged businessmen, and elderly retirees who use photovoltaics to power mountain retreats, vacation cabins, or year round residences. We talked to wealthy PV users in upper class neighborhoods and exclusive farms as well as young families or retirees using PV to power their modest cabins in remote areas.

This exploration takes you from the sunny beaches of Southern California to the occasionally shadowed hills of Northern California as well as the relatively severe and clouded climate of eastern Washington State just south of the Canadian border. Our intent is to provide information on a sampling of diverse installations in unique locations, purchased by different people for alternate reasons. We hope that these interviews will encourage you to contact PV dealers in your area to view local installations.

In our interviews, we discovered that some people have had problems with their systems. We candidly describe these problems in order to help the prospective purchaser avoid them or at least be prepared to deal with them. Overall we are impressed with the apparent satisfaction of PV owners, whether they have a simple system comprised of one module and a battery and some lights, or a much larger and elaborate system to provide for most domestic needs. There are many other installations (over 1,000) on the west coast of the U.S. that we selected from for the following representative samples.

\subsection{SOUTHERN CALIFORNIA INSTALLATIONS}

These interviews with southern California homeowners were carried out in June of 1981 through contacts provided by Solarwest Electic Company of Santa 
Barbara California and Wm. Lamb Company of Hollywood California. Photovoltaic power systems have proven to be cost-effective in a number of situations where utility power is within 500 yards of the site. In a growing number of areas it is not acceptable to install overhead powerlines, and the need to obtain easements and funds for the installation of underground power connections is sometimes prohibitive.

Currently available PV power systems now make it practical to build homes on excellent view lots regardless of proximity to utility lines. The simplicity and reliability of photovoltaic power supplies provides for ease of installation, no disturbance to the surroundings, and a secure and long lasting energy supply. Although the initial costs of such systems are significant, the freedom from ongoing regulatory and financial requirements associated with utility interconnection frequently override PV system costs.

Doug and Nancy Ingolsby live in the Santa Barbara area with two small children. Their PV system has eight $35 \mathrm{~W}$ panels storing energy in about $300 \mathrm{Ah}$ of storage batteries at $24 \mathrm{~V}$ DC. They operate lights at $24 \mathrm{~V}$ DC using special ballasts, and a $2500 \mathrm{~W}$ inverter which supplies power for a stereo systems, a television, a vacuum cleaner, a washing machine and a gas heated clothes dryer. They have sufficient power to do a load of wash daily and meet other typical daily electrical needs. They use gas to power their refrigerator and range.

Because of their remote location, Southern California Edison determined that it was "impossible" to provide power to them. Originally, the Ingolsbys' sole electric supply was a Honda gasoline generator. As they became increasingly concerned about the cost of fuel and the noise associated with its use they began to actively investigate alternative power systems. They ruled out a wind system "because it is mechanical". They report that information on PV was hard to find, but perseverence paid as their satisfaction with their system's performance testifies.

They report that they are very satisfied with their PV systems performance over the past year and feel that a major influence slowing the acceptance of PV power supplies is a lack of helpful information. They were quite pleased to contribute to this effort particularly in light of some of the misinformation 
being published. They expressed their incredulity when while reading a popular magazine with PV powered light, they came upon a full page advertisment by America's Electric Energy Companies stating that "technology to generate electricity from the sun on a large scale is still a long way from being practical and economical."

John Beaman is a young professional living in a house overlooking the Santa Barbara harbor. His home has been equipped with a four module packaged system obtained from SolarWest Electric Company in 1978. The system provides power for lights, stereo system, television, power tools and an air circulation fan. A 500 watt Triplite invertor provides AC power for the stereo and television. Even though there is no back up system, John reports that he has never been short of power. In the future he plans to power a hot tub pump with the PV power system.

At a year round residence in the foothills of northeast Santa Barbara, Rob and Grace Robinson (see Figure 7.1) present a convincing example of photovoltaic power as a viable alternative energy source. Although the site is only 600 feet from the utility grid the high cost of using utility power prompted the Robinisons to install a solar electric system. Not only does their PV system provide the electricity for their daily needs, it supplied all of the electrical power needed for the home's construction!

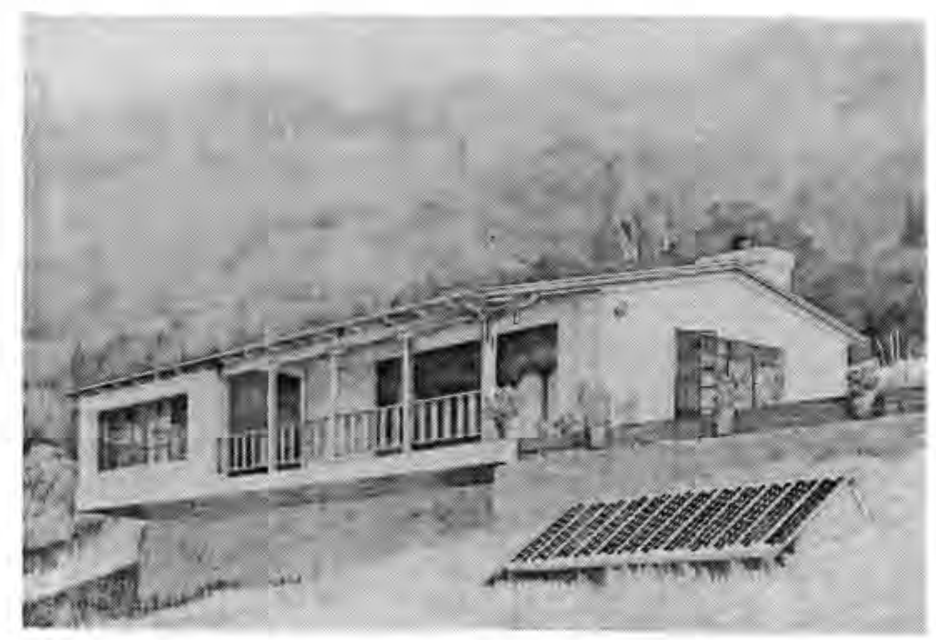

FIGURE 7.1. The Robinson Home 
The ir system has twelve $35 \mathrm{~W}$ modules and a battery bank comprised of twelve Delco 1150 storage batteries connected in such a way as to store power at 24 Volts DC. This power is used directly to provide fluorescent lighting and television reception or is converted either to $12 \mathrm{~V} D C$ through a power convertor or to $120 \mathrm{VAC}$ through a $2500 \mathrm{~W}$ inverter before delivery to other electrical loads. The house is wired for both $D C$ and $A C$ with each outlet having both an $A C$ and $D C$ socket. This allows for the use of efficient $D C$ lights and the convenience of $A C$ appliances. The inverter is manualiy controlled by switches located close to the outlets.

The system presently powers 17 interior lights, 3 outside lights, stereo, TV, toaster, blender, juicer, fans, power tools, washer and the dryer motor, vacuum cleaner, and a Jacuzzi pump for an average daily electrical requirement of 1500 watt hours. At this level of consumption the systems storage capacity of 13,000 watt hours could power the home for 5 to 7 days without sunlight. In addition to the PV electricity the homes other energy sources include propane for cooking, refrigeration, and hot water as well as passive solar features and a convection fireplace for space heating.

The home has been occupied full time by two adults since it was completed in August of 1980. The Robinsons report that there has always been ample power and there have been no major problems with the system except for the repair of the inverter in March which was accomplished under the manufacturers warranty. The payback on the $\$ 10,000$ system was immediate in light of the tax credit (combined Federal and state) applicable and the $\$ 4000$ cost of connecting the home to a utility line had the system not been installed.

Rick and Lynn Scott and their two small children live in a beautiful adobe home in the foothilis overlooking Santa Barbara. It became one of the very first homes to use $A C$ from photovoltaic power when the system was installed in 1978 (see Figure 7.2). When the Scott's learned that it would cost $\$ 7,500$ to bring utility power up 1000 feet to their home, they reasoned the $\$ 13,000$ cost of a photovoltaic system (less the 55\% tax credit) made solar electricity a cost effective alternative.

Their 16 panel system charges twelve Delco 1150 batteries at 48 volts DC. Before the power is used, it is converted to $120 \mathrm{~V}$ AC with a $5000 \mathrm{~W}$ load 


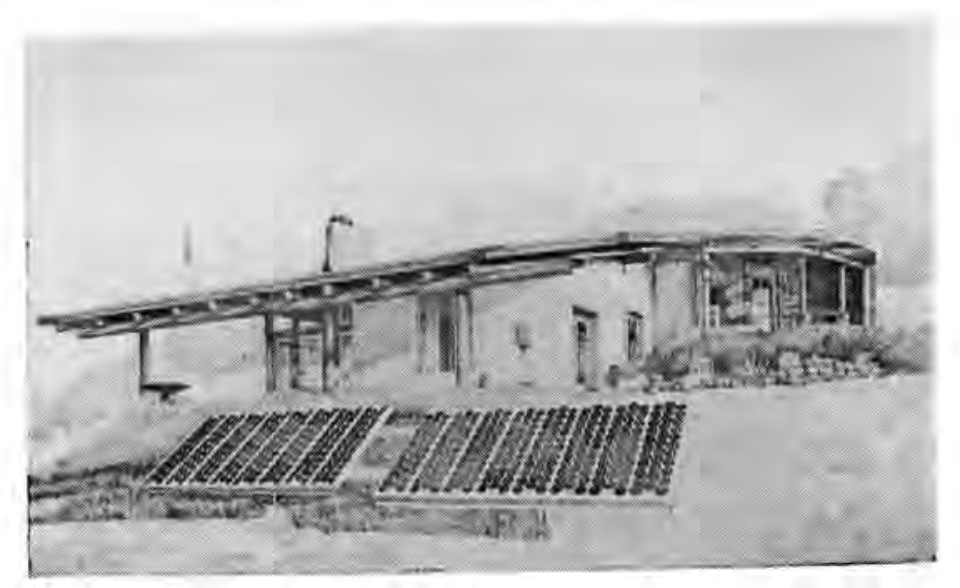

FIGURE 7.2. The Scott Home

demand start inverter. The power is used for 12 interior lights, toaster, stereo, blender, vacuum cleaner, table saw, skil saw, and a juicer for an average of 2,500 watt hours daily. The system provides an average of 3000 watt hours daily and the storage system of approximately 13,000 watt hours can sustain standard building operation for four to five days without sunshine.

This home is similar to the Robinson home in that propane is used for cooking, refrigeration and hot water; and passive solar and wood are used for space heating. The PV system has proven to be a reliable and easily maintained power supply with a satisfactory overall operation. One annoyance that the Scotts revealed is that the load demand start on the inverter does not work for very small loads such as a night light or stereo. Therefore, it is necessary to turn on some other appliance or light to start the inverter.

Jim and Donna Christensen have a 3,300 square foot home in Solvang, California (see Figure 7.3) that was built entirely by PV powered equipment. Although they could now connect to the utility grid, the Christensens choose to enjoy the independence their private electric system provides. They report that "the beautiful part of the PV system is that we are not connected to the utility."

They have twenty-seven 35 watt modules connected to charge thirty Delco 2000 batteries at 120 volts DC. A 6 KVA (approx 6000 watt) inverter is 


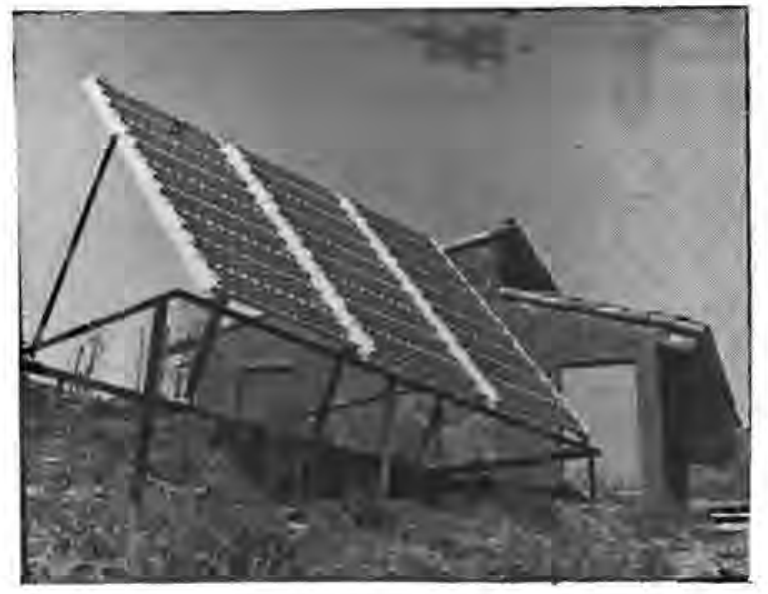

FIGURE 7.3. The Christensen Home

utilized to provide 120 volt AC power for all electrical appliances except for cooking and water heating. This installation is the largest we know of which has been done without government assistance. Except for a few problems that are being corrected, they are very pleased with their system.

The Brisa Del Mar Ranch is one of several in an exclusive limited entry area of the coast near Santa Barbara called the Hollistor Ranch. Dodd Geiger and Gebb Turpin have recently installed a PV powered drip irrigation system (see Figure 7.4) supplying water for 200 avocado trees and 100 citrus trees as well as a large garden. A $4 \mathrm{KW}$ Jacobs wind generator supplies electricity for a barn on their ranch with backup supplied by a $6 \mathrm{Kw}$ propane powered Wisconsin generator. Although the wind system performs well, it is periodically necessary to call in outside help to replace the wind turbine brushes since the owners "don't want to climb any 40 foot tower!"

Their irrigation system is powered by twelve $35 \mathrm{~W}$ modules connected for 24 $V D C$. They use about 250 Ah of storage battery to store the early morning sun while the power is too low to operate the progressive cavity pump. The progressive cavity pump, located at $120^{\prime}$ depth, is driven by a permanent magnet DC motor on the surface. The pump system by Blue Sky Water Supply Company is 


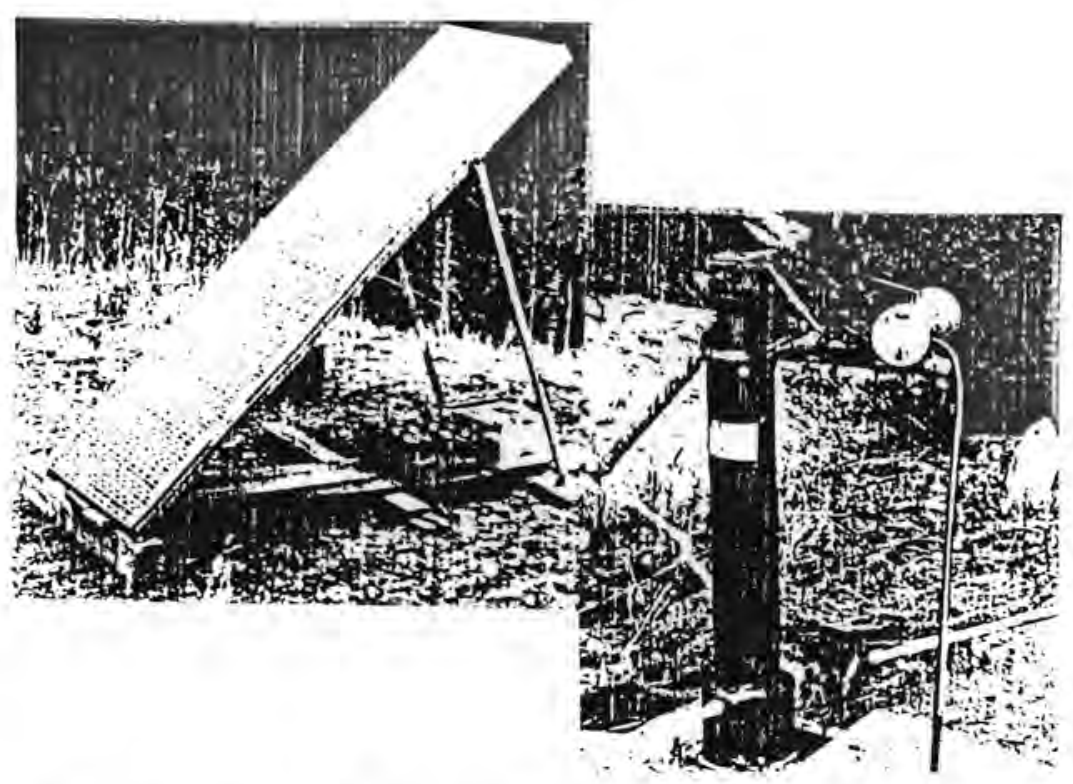

FIGURE 7.4. PV Powered Drip Irrigation System

rated at 2000 gallons per day. The system is currently in a debugging stage, but promises to be a dependable and easily maintained water supply.

William and Sandy Merrill are moving onto a ranch east of Los Angeles where they currently use PV power to pump water and plan to add capacity for domestic lighting and appliance use. Part of their ranch is almost directly under three high voltage power lines (see Figure 7.5). In order to connect to the utility they would have to expend about $\$ 4,000$ for underground cable, many hours of labor to install it, and obtain an easement from a neighbor who is not cooperating with power companies at this time. They say that PV is an excellent solution to their problem and they like it's quiteness and lack of maintenance.

The water pumping system was installed by William Lamb Company and provides water for livestock, gardening, and domestic use. The installation is termed sun-synchronous since no batteries are used, and water is pumped in direct relation to the available sunlight. The power for the jack pump which lifts 250 gallons per hour from a 230 foot deep well is provided by twelve 35 watt PV modules. Watching their pumping system may not be exciting ("it just keeps on pumping") but without it the land is scorched brown most of the year rather than a productive growth area for produce and livestock. 


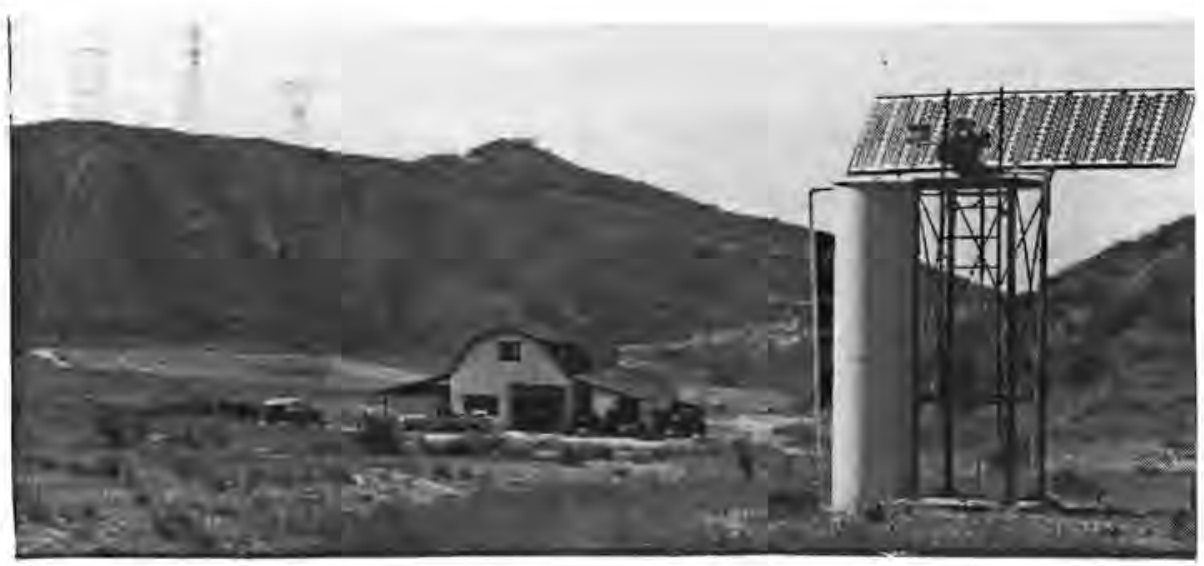

FIGURE 7.5 TAE Merril1's Pumping System

Although the water system is working perfectly now, there were startup problems which needed to be worked out. Initially the counterweight was insufficient and the pulleys weren't correctly matched to the motor and pump. It is extremely helpful to have a knowledgeable dealer help with system debugging so as to quickly achieve maximum performance.

The installations discussed above are representative of activity in Southern California. As this goes to press, many more installations are planned or underway in addition to many which are now in operation but not discussed for the sake of brevity. If you live in a climate similar to that of the sunny southwestern United States, these experiences should give some insight into the performance of PV power supplies. We now travel northward so that you can see the uses of PV in climates with less sunshine.

\subsection{NORTHERN CALIFORNIA INSTALLATIONS}

A wide spectrum of PV system users was encountered in northern California ranging from business and professional people to those espousing an "avante guarde" lifestyle. Some of the PV owners contacted were hesitant to speak with us because they value privacy very highly; often, this was a motivating factor in their decision to purchase their systems. We have used pseudonyms to protect those who expressed a concern about it.

The instal1 ations described in this section were inspected in June of 1981 , and resulted from contacts provided by Jim Cullen Enterprises, Inc. of Laytonville California, Solar General Store of Yarberville California, and Jim Padulla of Padulla Lumber and Co. in Willits California. 
Linda McVarish (see Figure 7.6) and Travis Kock live in the Laytonville, California area (P.0. Box 575). They have a hybrid system with four $35 \mathrm{~W}$ panels and a wind generator charging a 500 Ah $12 \mathrm{~V}$ battery bank. They power 3 fluorescent lights and a dozen incandescent lights at 12 volts and small appliances at $120 \mathrm{~V}$ AC using a Tripplite $550 \mathrm{~W}$ inverter.

They report that the weakest links in this system are the wind generator ("We may relocate it"), and the inverters. Overall they like the PV system very much and plan to add to it when "the price comes down". They started the backup gas generators about 4 times last winter to charge the batteries during extended cloudy periods, but they expect the generator to "last forever" with the PV and wind system carrying most of the load. Their Servel refrigerator uses 20 gallons of propane in 6 weeks and they are using a gas motor to pump water $100^{\prime}$ up a hill to a redwood storage tank. In the future, they plan to use PV to operate the refrigerator and pump water.

Suzanne Rick, Box 323, Laytonville, California uses four $35 \mathrm{~W}$ solar modules to power 2 black and white TVs, a stereo, 6 fluorescent, two incandescent lights as well as operate a "cottage industry". She makes original ceramic do11s, and sews authentic costumes for them. The system exceeds her expectations and she would like two more panels ("I use a lot of light"). The system

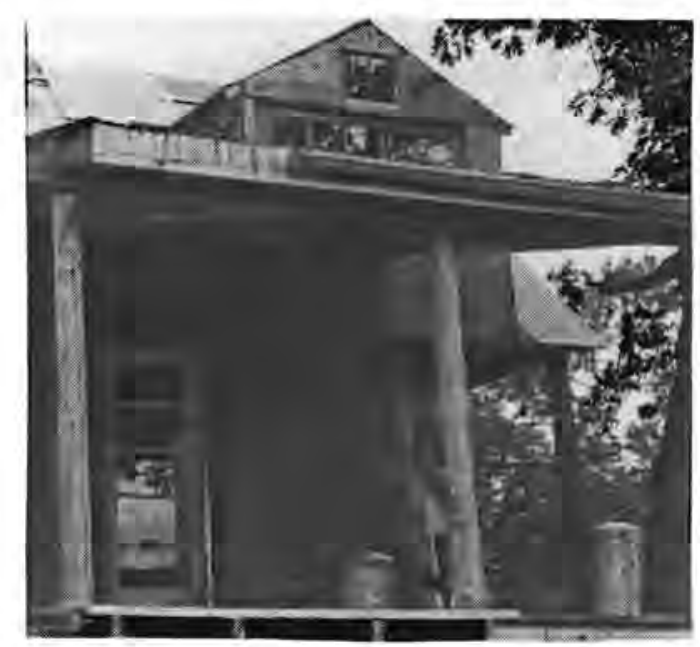

FIGURE 7.6. The McVarish Home 
could also use an elevated adjustable mount for the two panels which are shown in Fiqure 7. mounted on the rafters. The site is less than ideal with trees located all around. Many installations are less than ideally located, but owners are realistic and very pleased with the performance actually obtained.

The James P. Lowary family (P.0. Box 842, Laytonville, California) has ten $18 \mathrm{~W}$ panels charging $500 \mathrm{Ah}$ of batteries (Figure 7.8 ). They operate a color TV, radio, lights, a tape deck, and other $12 \mathrm{~V}$ appliances. They have no inverter and operate the $A C$ appliances such as vacuum cleaners from a Honda $A C$ generator powered by propane. They are delighted to eliminate most of the noise and expect that the Honda will last indefinitely with the PV system carrying the major load.

The Lowary's are retired and appreciate controlling their expenses. They have no desire for utility power even if it could be had for less than the $\$ 100,000$ estimated to extend the power line. They believe the system is not delivering its rated output but they haven't experienced power shortages. They charge the batteries while operating the washing machine, vacuum, etc. with the excess power from the generator. They enjoy the simplicity of PV.

Jerry Martin (P.0. Box 627, Laytonville, California) has six $18 \mathrm{~W}$ panels charaing 500 Ah of battery storage. He has a $500 \mathrm{~W}$ inverter used to power

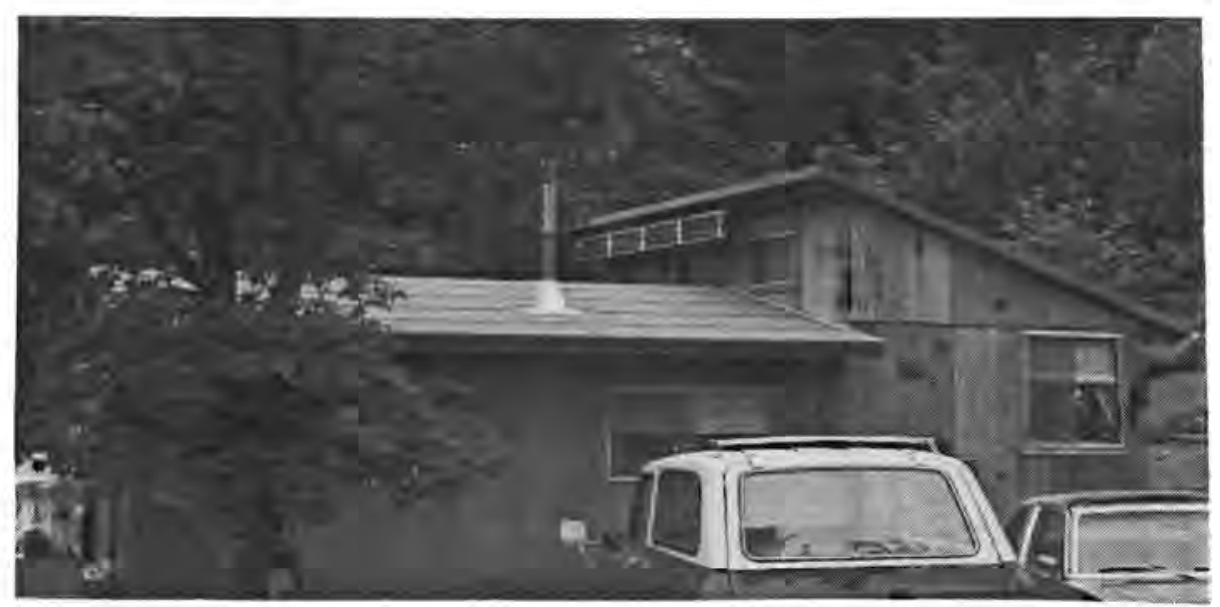

FIGURE 7.7. The Rick Home 


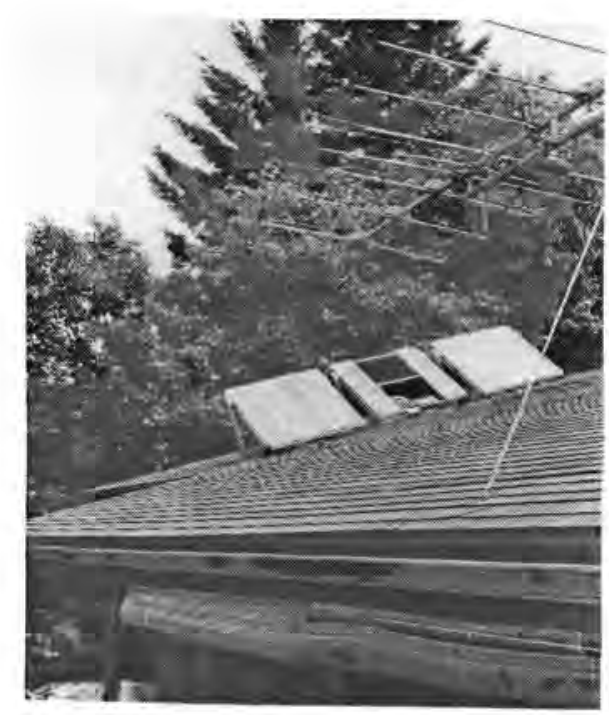

FIGURE 7.8. The Lowary Home

light hand tools. In addition, he powers a TV, stereo, radio, several fluorescent and incandescent lights. He is absolutely sold on PV and plans to add five $35 \mathrm{~W}$ panels next month and five more in September. He does not have a regulator on the system and uses a hydrometer to check the batteries once a week. He cleans the battery terminals every two to three months.

Mr. Martin uses the system to provide power to both the trailer and the cabin (see Figure 7.9). He plans to power the refrigerator from PV and perhaps pump the water with it as he enlarges the system.

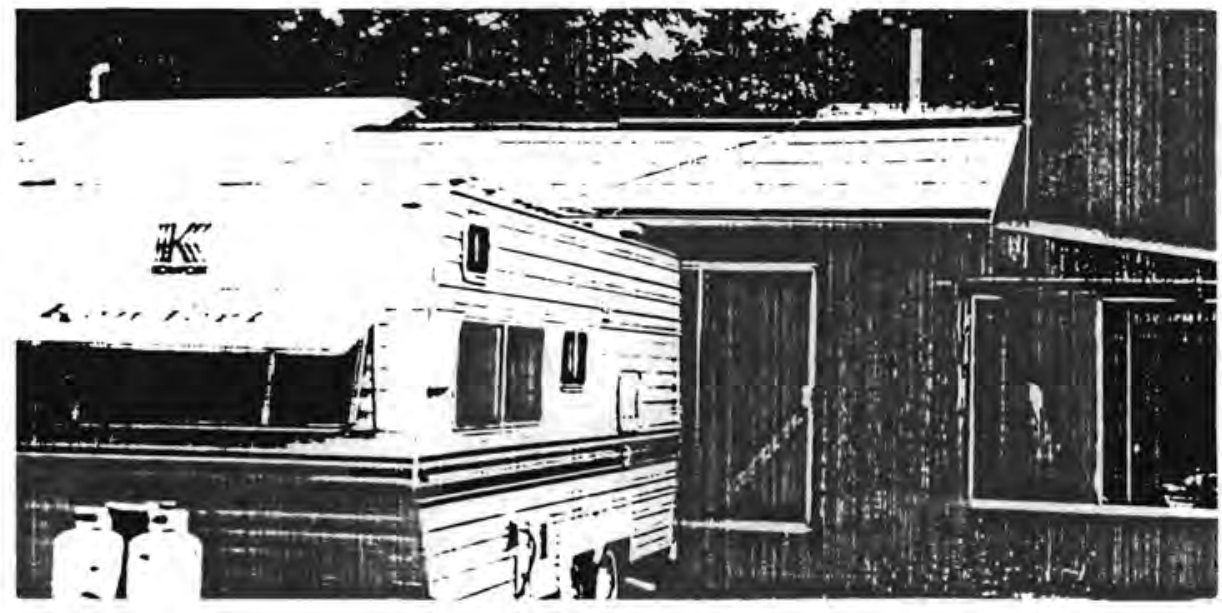

FIGURE 7.9. The Martin Home 
There are a number of systems in the Garberville, California area whose owners prefer the solitude of the countryside and would not allow their names or pictures of their installation to be published. One of these whom we shall call John Doe has sixteen $35 \mathrm{~W}$ panels connected to a 3,500 Ah battery bark that drives a Best $2500 \mathrm{~W}$ inverter to supply $120 \mathrm{~V}$ AC. A propane generator was used previously and the noise free PV system is most appreciated. He is satisfied with the PV system and would like to enlarge it soon so as to offset the $\$ 20 / \mathrm{mo}$ propane cost required to fuel his Servel refrigerator.

John Doe II has installed six $35 \mathrm{~W}$ modules with 700 Ah of battery storage that are protected by a Specialty Concepts regulator. This system is used to power a couple of stereo/radios, a TV set, and numerous fluorescent and incandescent lights in the main cabin as well as a $14^{\prime}$ RV. A special application of note is the powering of a DC fan to enhance the effectiveness of a wood stove. He plans to add approximately 8 more panels and an inverter to power a refrigerator and other AC appliances. He was pleased to have less generator noise and looks forward to the larger system that will further reduce propane generator operation.

Other than the replacement of a defective controller in November of 1980, the system has proven to be a $100 \%$ reliable power source -- even during the cloudy winter months. The owner feels that such reliable power could not be provided by the utility grid even at the estimated cost of $\$ 50,000$ for the necessary line extension.

John Doe III built a 1100 S.F. home in a remote area more than ten miles from the nearest power line. Eight months ago he installed four $35 W$ PV modules to power a variety of $12 \mathrm{~V}$ appliances providing music, entertainemnt, and light. Mr. Doe III is totally satisfied with the system although he did experience a regulator failure which had to be replaced soon after installation. He plans to add four additional panels to power a refrigerator.

We spoke with a customer selecting a module and a 95 Ah battery to power a fluorescent light and a stereo radio. He was pleased to be able to avoid filling the kerosene light in the cabin (particularly during inclement weather) and avoid the odor of kerosene that dominated his environment. Furthermore, without the convenience of a PV power supply the enjoyment of radio broadcasts would be limited by continuous replacement of batteries. 
The northern California homeowners we talked to are pleased with their PV systems and confirm that performance is as expected. Most plan to buy more panels "when they can afford it". This allows them to have the immediate convenience that a small system can provide usually for lighting and entertainment systems and the opportunity to gain first hand knowledge of system performance prior to making a large investment.

\subsection{NORTHEASTERN WASHINGTON INSTALLATIONS}

The installations discussed in this section were inspected in July of 1981 as a result of contacts with the Northeast Washington Appropriate \& Creative Technology Organization (NEW ACT). In recognition of the potential value of PV systems to bring the benefits of electrical power to remote residences in the region, the organization sponsored public discussions of photovoltaics and arranged a block purchase in December of 1980 and again in July of 1981 . All but one of the systems described below resulted directly from these efforts.

The earliest installation in the region went into operation in 1978 and has provided reliable power for a stereo sound system in a remote mountain retreat (Figure 7.10). One 24 watt Solarex panel is connected to a small aircraft "gel

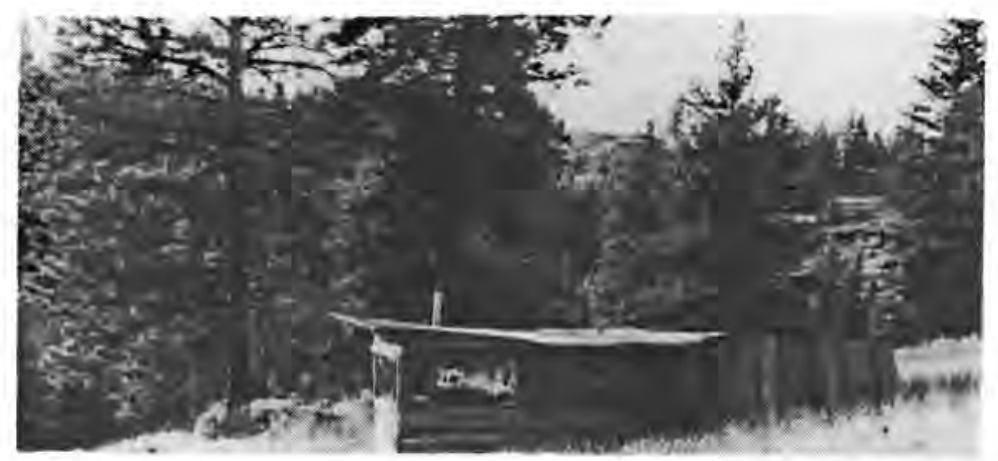

FIGURE 7.10. PV Powered Mountain Retreat 
cel1" to power the DC tape player and amplifier. The builder and resident of the retreat home plans to add some small incandescent lights in the near future and comments that her desire for privacy and independence lead her to use photovoltaics. Since the only access to the home is by a steep 500 plus yard trail, lugging batteries, gas generators and fuel, or a wind machine would be difficult. The lightweight photovoltaic panel has proven to be a reliable and trouble free power supply which preserves the silence and pristine naturalness of the site.

The home of Mike Nelson and his wife and teen-aged daughter (Figure 7.11) is an interesting and effective mix of alternative and creative technologies to provide for independent living. The passive solar, partly earth sheltered home employs a small wind generator, two photovoltaic panels, and a 380 amp hour battery storage system to provide power for lighting, home entertainment, and ventilation. Although the cost of connecting the house to nearby power lines is only about $\$ 500$, Mr. Nelson enjoys the freedom from the requirements and ever escalating costs which utility interconnection would invite.

A look at the history of the home's energy systems provides insight into the appropriateness of the current system. During the construction of the home

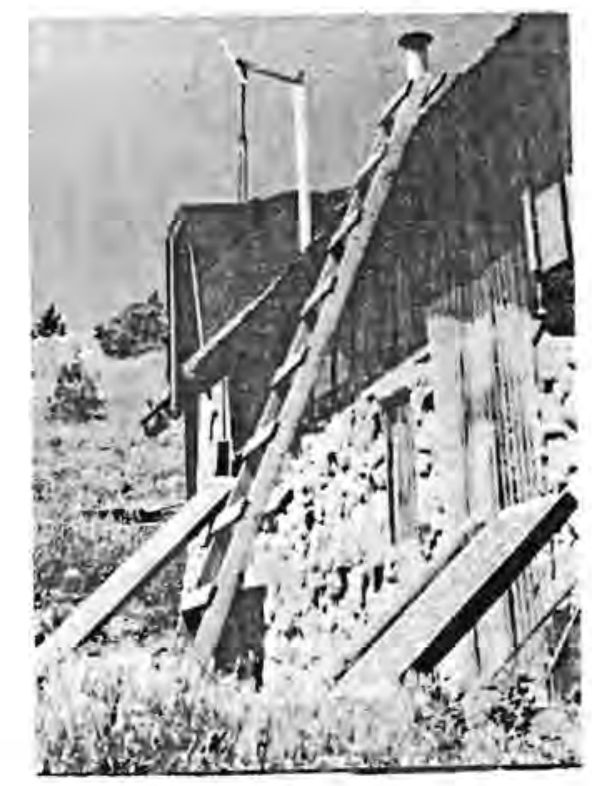

FIGURE 7.11 The Nelson Home 
a 1,500 watt gasoline generator was purchased to provide the electricity for power tools (Figure 7.12). This same generator provides the large amounts of power for clothes washing and power tools, but is not required for other typical needs. A 200 watt Winco wind turbine mounted atop a $28 \mathrm{ft}$ mast was erected soon after the shell of the house was completed and provided intermittent charging for the 12 volt batteries. The latest addition of two ArcoSolar 35 watt panels in December of 1980 and an inexpensive diode has made the system $100 \%$ reliable. Soon Mr. Nelson plans to install a home built 1000 watt wind generator on a 65 foot tower, as well as additional PV modules.

The system powers four 15 watt fluorescent fixtures, two 25 watt incandescent lights, one 25 watt stereo, and a one amp vent fan on a composting toilet. An 50 watt invertor purchased from the J.C. Whitney catalog for $\$ 19.95$ provides for occasional AC needs such as a turntable. Mr. Nelson states that the maintenance on the system is minimal, only occasional inspection with the hydrometer and topping off of the battery fluid with distilled water. He is completely satisfied with the photovoltaic performance and plans to add more capacity as finances permit to power a small refrigerator.

Dean and Anne Fischer/Lawson have installed a 35 watt panel to provide power for sound and lighting systems. Presently the panel is connected to a

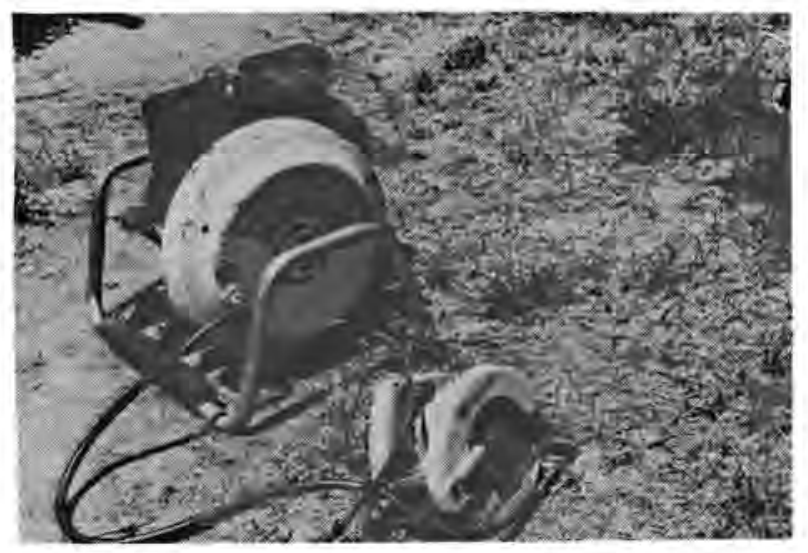

FIGURE 7.12. 1500 Watt Gas Generator 
100 amp hour storage battery which in turn energizes a DC tape deck and amplifier. The home, depicted in Figure 7.13, is more than three miles from the nearest power lines and the only other source of electricity is a rather large 6000 watt Honda gas generator. It would not be cost effective to run this large unit to provide the energy needed for the stereo and small lights. Apparently another panel is planned for the near future since the support frame is already installed.

A local carpenter known as Boone installed a 35 watt panel on his remote residence in January of 1981 . The home which is well insulated and includes an attached greenhouse with rock storage to provide both heat and nourishment, is depicted in Figure 7.14. Prior to the PV panel the only electricity available was from storage batteries or a gasoline generator, neither of which was convenient to provide power for lighting and entertainment systems.

The panel is connected to a 100 amp hour snowmobile battery without a voltage regulator. Boone insists that all that is necessary is an occasional topping off of the battery fluid, and that anyone capable of installing an automotive back up light should have no problem with system installation or

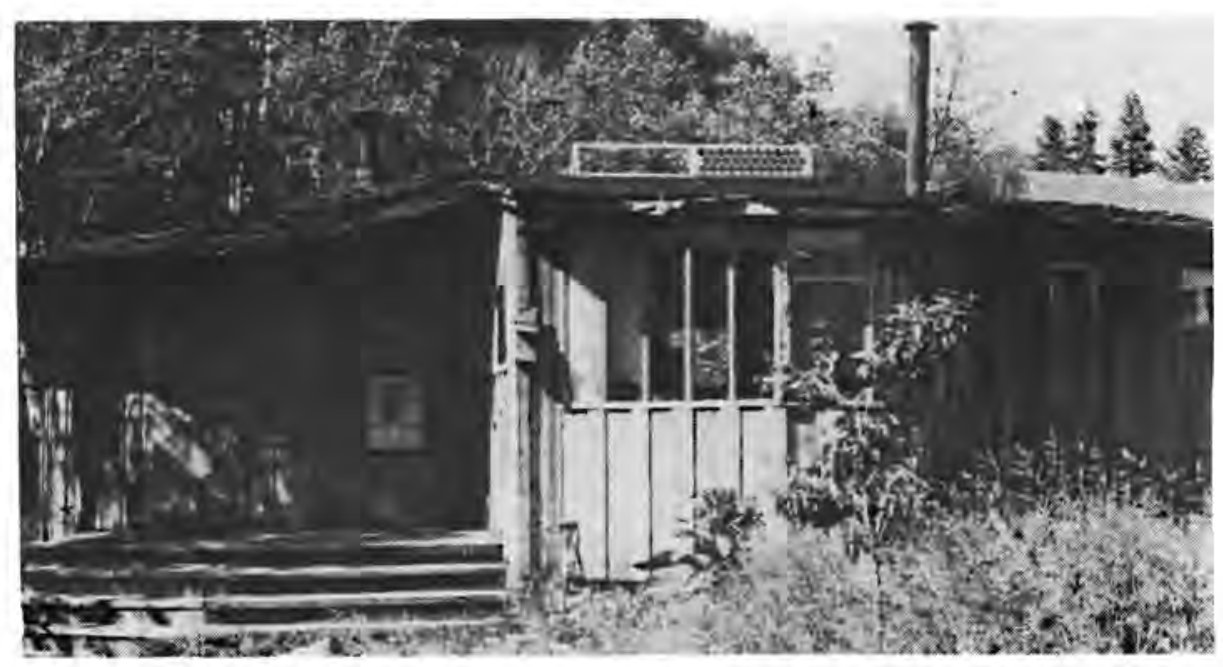

FIGURE 7.13. The Fischer/Lawson Home 


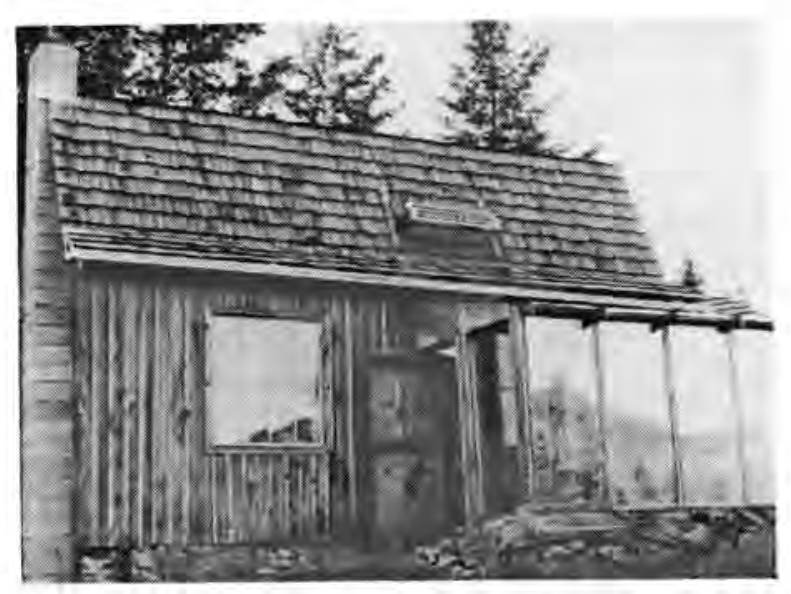

FIGURE 7.14. The Boone Home

maintenance. His wife is glad to be free from the inconvenience and danger of kerosene lighting and enjoys the home sound system. Boone plans to add additional panels to power a refrigerator in the future.

The PV users in this northern climate receive an average of 2 to 4 peak sun hours per day, and report that they are completely satisfied with system performance. Although their systems are modest they provide a substantial improvement in their lifestyle. No longer must odorous and expensive kerosene be burned for lighting, and the enjoyment of stereos can be had without the noise of gas generators or the inconvenience and expense of transporting batteries. It is surprising that so much convenience can be had at such a modest cost.

\subsection{SUMMARY OF USER EXPERIENCES WITH PV}

The PV owners whom we interviewed in California and Washington were quite pleased with the performance of their PV systems. Occasionally minor problems did arise; however, these were not significant enough to prevent owners from expanding their systems. 
Our interviews revealed a fairly consistant pattern of PV system expansion. Most owners begin with 1 to $635 \mathrm{~W}$ PV modules and a few automobile or golf cart storage batteries. These small systems can be purchased for as little as $\$ 500$, and will provide power for high priority needs such as music and lighting. Of course, man cannot survive on music and lighting alone, so many users supplement their PV system with a $1750 \mathrm{~W}$ Kohler or similar gas generator $(\$ 500)$. This allows the owner to operate vacuum cleaners and other appliances and provides backup to the PV system. Backup lighting is also provided by candles or kerosene.

Once an owner has built-up confidence in a PV system, he enlarges the system by adding a few more panels, batteries, a charge controller and an inverter. This larger system will provide sufficient power for operating most household appliances intermittently except for heating and cooling units and sizeable induction motors. These systems have performed well, and owners seldom use propane or gas generators except in the northern climates.

Some PV owners have enlarged their systems to 16 or more $35 \mathrm{~W}$ modules, added more batteries and a larger inverter. This size system is capable of operating all typical AC appliances (except heating and cooling units), minimizing life style changes.

The particular size system that you should purchase depends upon your energy needs, income, location and willingness to accept lifestyle changes. The authors strongly recommend that anyone who is considering a PV system visit a few installations in their area. 
APPENDIX I

FINANCIAL INCENTIVES FOR PHOTOVOLTAIC ENERGY SUPPLIES 


\section{APPENDIX I: FINANCIAL INCENTIVES FOR PHOTOVOLTAIC ENERGY SUPPLIES}

The federal government and many state governments offer a variety of financial incentives to stimulate the purchase of renewable energy systems, which usually apply to PV systems. These incentives, if applicable to your installation, significantly affect net purchase cost by allowing the purchaser to:

0 exempt the value of the system from property taxes,

- credit part of the installed cost against income taxes, and/or

0 be exempt or obtain a refund for sales taxes.

The applicability of these incentives will vary depending upon the location and nature of your installation.

As a guide to determine the types of incentives available we have assembled information on federal and state incentive plans. This information is updated frequently by the National Solar Heating and Cooling Information Center who will provide the information free of charge by request by calling the numbers listed. Further information can be obtained from your state energy office. 


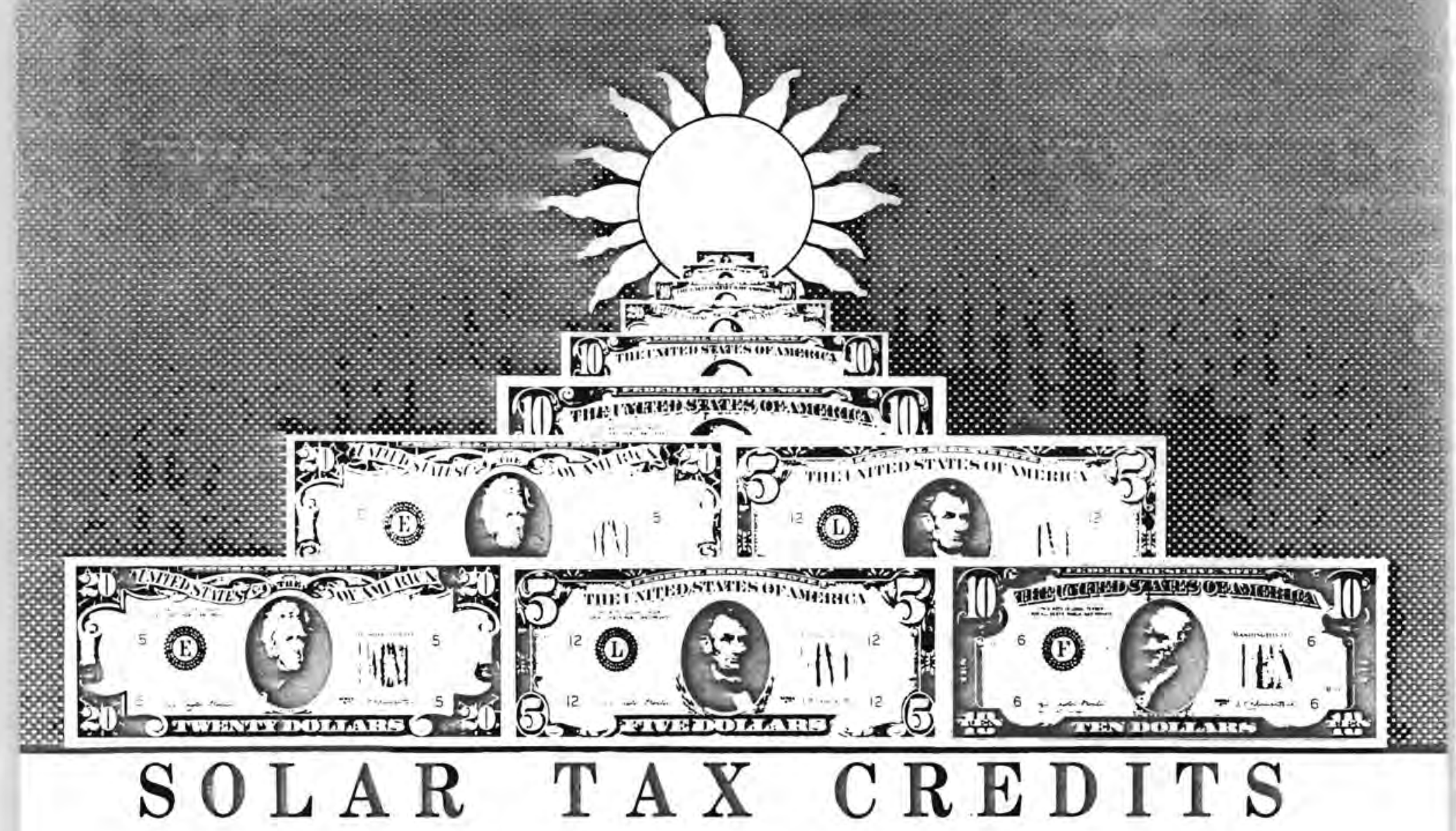

In an attempt to help

Americans reduce their consumption of nonrenewable fossil fuels, Congress passed the Crude Oil Windfall Profit Tax Act in 1979. Signed by President Carter in 1980, The Act includes the following solar tax credits.

Residential: Beginning January 1,1980 , the Federal Government is offering a 40 percent nonrefundable tax credit for investments designed to utilize renewable energy sources in both new and existing residences. This includes technologies for heating or cooling homes, supplying hot water, producing electricity, or harnessing wind or geothermal energy. The credit applies to investments up to $\$ 10,000$ a year, yielding a maximum tax credit of $\$ 4,000$. To qualify, the investment must be made by December 31,1985 , but the tax credit may be carried over until 1987. This increases the earlier effective 22 percent nonrefundable tax credit which began on April 20, 1977.

Business Energy Investment Credits: Businesses can receive a 10 percent refundable tax credit for investments in renewable resource property installed between October 1, 1978, and December 31, 1979. On investments made between January 1 , 1980 , and December 31,1985 , the Federal Government offers a 15 percent nonrefundable tax credit. Examples of eligible investments would be solar equipment to heat or cool buildings or to supply hot water, or technology utilizing wind energy. In addition, the government offers a 10 percent invest. ment credit for biomass property acquired between October 1, 1978, and December 31,1985 . For certain alcohol fuels, a 4 per gallon excise tax exemption is available to some producers.

Tax laws are complicated; to learn how they apply specifically to you, please write or call:

National Solar Heating and Cooling Information Center P.O. Box 1607

Rockville, MD 20850 (800) 523-2929

Pennsylvania: (800) 462-4983

Alaska \& Hawaii: (800)

$523-4700$ or your local IRS Office.

Approximately 20 states also have tax credit programs, energy grants, and other solar energy investment incentives. For further information please call your state representatives or your state energy office.

U.S. Department of Energy

Assistant Secretary for Conservation and Solar Energy

Office of Solar Applications

for Buildings

August 1980

DOE/CS-0186 


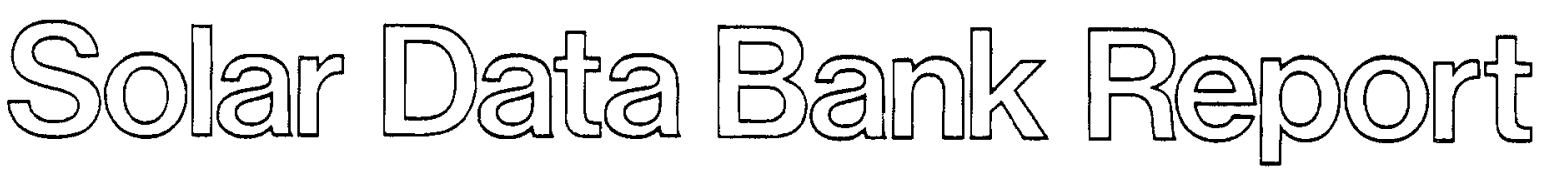

STATE TAX BREAKS FOR RESIDENTIAL SOLAR SYSTEMS

State

Alabama

Alaska

Arizona

Arkansas

California

Colorado

Connecticut

Delaware

Florida

Georgia

Hawaii

Idaho

Illinois

Indiana

Iowa

Kansas

Kentucky

Louisiana

Maine

Maryland

Massachusetts

Michigan

Minnesota
Property Tax Exemption

no

no

exemption

no

yes

exemption

local option

no

exemption

local option

exemption

no

exemption

exemption

exemption

exemption; refund based on efficiency of system

no

exemption

exemption

exemption statewide plus credit at local option

exemption

exemption

exemption
Income Tax Incentive

SaZes Tax Exemption

no

no

up to $\$ 200$ credit

not applicable

up to $\$ 1000$ credit

exemption

$100 \%$ deduction

no

up to $\$ 3000$ credit per no

application

up to $\$ 3000$ credit no

not applicable

exemption

$\$ 200$ credit for DHW

not applicable

systems

not applicable

exemption

no

refund

$10 \%$ credit

no

$100 \%$ deduction

no

no

no

up to $\$ 3000$ credit no

no

no

up to $\$ 1500$ credit no

no

no

no

no

up to $\$ 100$ credit

refund

no

no

up to $\$ 1000$ credit

exemption

up to $\$ 1700$ credit

exemption

up to $\$ 2000$ credit

no

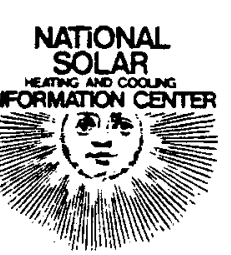

DR-107

04/80, rev. 03/81

The Center is operated by the Franklin Research Center for the U.S. Department of Housing and Urban Development and the U.S. Department of Energy. The statements and conclusions contained herein are based on information known by the Center at the time of printing. Periodlc updates are available. For more information, piease contact us at P.O. BOX 1607, ROCKVILLE, MD 20850 or call toll free (800) 523-2929. In Pennsylvania call (800) 462-4983. In Alaska and Hawaii call (800) 523-4700. 
STATE TAX BREAKS FOR RESIDENTIAL SOLAR SYSTEMS

State Property Tax Exemption

Mississippi no

Missouri no

Montana exemption

Nebraska no

Nevada limited exemption

New Hampshire local option

New Jersey exemption

New Mexico no

New York

N. Carolina

N. Dakota

Ohio

Oklahoma

Oregon

Pennsylvania

Rhode Island

S. Carolina no

S. Dakota

Tennessee

Texas

Utah

Vermont

Virginia

Washington

W. Virginia

Wisconsin

Wyoming

\section{exemption}

exemption

exemption

exemption

no

exemption

no

exemption

exemption

exemption

exemption

no

local option

local option

exemption

no

exemption

no
Income Tax Incentive

no

no

up to $\$ 125$ credit

no

not applicable

not applicable

no

up to $\$ 1000$ credit

no

up to $\$ 1000$ credit

$5 \%$ credit for two

years

up to $\$ 1000$ credit

up to $\$ 2800$ credit

up to $\$ 1000$ credit

no

up to $\$ 1000$ credit

up to $\$ 1000$ deduction

not applicable

not applicable

not applicable

up to $\$ 1000$ credit

up to $\$ 1000$ credit

no

not applicable

no

no*

not applicable
Sales Tax Exemption

exemption for colleges, junior colleges and universities

no

not applicable

refund

no

not applicable

exemption

no

no

no

no

exemption

no

not applicable

no

refund

no

no

no

exemption

no

no

no

no

no

no

no

*Wisconsin offers a direct rebate for part of solar expenditures; the rebate is unrelated to taxes. 
APPENDIX II

ADDITIONAL SOURCES OF INFORMATION 


\section{ADDITIONAL SOURCES OF INFORMATION}

In this directory, we have tried to give you an idea of the photovoltaic systems/products that are available, and how they can help you meet your energy needs. Although we've raised many questions that you should consider when choosing a system, we haven't raised or answered them all. This section will help you locate the answers to your questions. We have compiled a list of research organizations that can provide you with additional information on government-funded PV installations. Also, we have included a list of books that have proven to be quite helpful in preparing this directory. Many of these books should be available through your public library. 
RESEARCH ORGANIZATIONS

Aerospace Corporation

Stanley Leonard

P.0. Box 92957

Los Angeles, CA 95081

(213) $648-7040$

Battelle Pacific Northwest Laboratory

Raymond L. Watts

Sigma-4

Box 999

Richland, WA 99352

(509) $376-4348$

Jet Propulsion Laboratory

Elmer Christensen

4800 0ak Grove Dr.

Pasadena, CA 91103

(213) $577-9077$

Massachusetts Institute of Technology

Lincoln Laboratory

Marv Pope

292 Main Street

Lexington, MA 02173

(617) $862-5500$

NASA/Lewis Research Center

Bill Brainard

21000 Brookpark Road

Cleveland, $\mathrm{OH} \quad 44135$

(216) $433-6840$

Sandia National Laboratory

Don Schueler

Division 4719

P.0. Box 5800

A1buquerque, NM 87185

(505) $844-4041$

Solar Energy Research Institute

Don Ritchie

1617 Cole Blvd.

Golden, CO 80401

(303) 231-1372 
OTHER HELPFUL ORGANIZATIONS

- American Section International Solar Energy Society American Technological University

PO Box 1416

Killeen, TX 76541

(817) $526-1300$

- Solar Energy Industries Association George Tenet

1001 Connecticut Avenue, N.W.

Suite 800

Washington, D.C. 20036

(202) $293-2981$

- Renewable Energy Institute John Wilson 1050 17th Street, N.W. Suite 1100 Washington, D.C. 20036 (202) 822-9157

- Photovoltaics Division, SEIA Raymond Kendall, Chairman Motorola, Inc. 8201 East McDowel1 Road Scottsdale, AZ 85257 (602) $949-3775$ 


\section{REFERENCES}

Bechtel National Inc. 1979. Handbook for Battery Energy Storage in Photovoltaic Power Systems. SAND 80-7022,, San Francisco, CA. The purpose of this handbook is to provide the photovoltaic system designer with a source of interface design considerations, as well as performance, cost and other necessary information involved with the development and design of photovoltaic systems .

Caskey, D.L., B.C. Caskey and E.A. Aronson. 1980. Parametric Analys is of Residential' Grid Connected Photovoltaic Systems with Storage. SAND 79-2331, Sandia National Laboratories, Albuquerque, New Mexico. This report investigates the cost of using battery storage in residential grid-connected PV applications.

Cullen, J. 1980. How to be Your Own Power Company. Van Nostrand Reinhold Co., New York, New York. This book provides a simple method for designing and installing your own power system.

Intermediate Technology Development Group. 1980. The Power Guide: A Catalog of Small Scale Power Equipment. ed. P. Fraenkel, Charles Scribner's Son, New York, New York. This guide is to help people who want to purchase small scale power equipment for use in remote and underdeveloped areas. It lists the pros and cons of choosing various power sources and the availability of these products internationally.

Jacobson, E., G. Fletcher and G. Hein. 1980. Photovoltaic System Costs Using Local Labor and Materials in Developing Countries. Prepared for NASA Lewis Research Center by the Engineering Extension Laboratory of the Georgia Institute of Technology, Atlanta, Georgia. This study addresses the costs of using photovoltaics in countries that do not presently have high technology industrial capacity.

Matlin, R. W. and M. T. Katzman. 1977. The Economics of Adopting Solar Photovoltaic Energy Systems in Irrigation. C0014094-2, Massachusetts Inst itute of Technology Lincoln Laboratory. Lexington, Massachusetts. This study compares the costs of PV and conventional fossil fuels as energy sources for irrigation. Also, an estimate is made of the time to initial profitability, and the time of optimal investment.

Maycock, P., David E. Stirewalt, 1981, Photovoltaics, Sunlight to Electricity in One Step, Brick House Publishing Co., Andover, MA. This book covers the story of PV from the unique perspective of a DOE Division Director. Autographed copies from author, $\$ 10$, paper, $\$ 20$, cloth.

NASA Lewis Research Center. 1980. Photovoltaic Stand Alone Systems: Preliminary Engineering Design Handbook. DOE/NASA/0195-8111, Cleveland, OH.

PRC Energy Analysis Company. 1980. Solar Photovoltaic Applications Seminar. McLean, VA. This report provided technical information on photovoltaic components and systems. 
Paule, T. D. 1981. How to Design an Independent Power System. Best Energy Systems for Tomorrow Inc., Necedah Wisconsin.

Richter, H. P. 1977. Wiring Simplified. Park Publishing, Inc., St. Paul, MN. This book has been written for people who want to learn how to install electrical wiring, so that the finished job will be safe and practical. The installation will comply with the National Electrical Code.

Sandia National Laboratory. 1981. Simplified Design Guide for Estimating Photovoltaic Flat Array and System Performance. SAND 80-7185, Albuquerque, NM. Provides a methodology for estimating PV array and system performance. This report also contains a solar weather data base for 97 U.S. locations.

Solarex Corp. 1980. Guide to Solar Electricity. Washington, D.C. Provides basic information on the operation and use of photovoltaic systems and components. About $\$ 7.95$ plus handling and postage from Solarex Corp.

Stewart, J. W. 1979. How to Make Your Own Solar Electricity. Tab Books, Blue Ridge Summit, PA. Discusses how PV cells work, the various applications of PV and the future of PV. 
APPENDIX I I I

DOT MATRIX OF MANUFACTURING 
DOT MATRIX OF MANUFACTURING

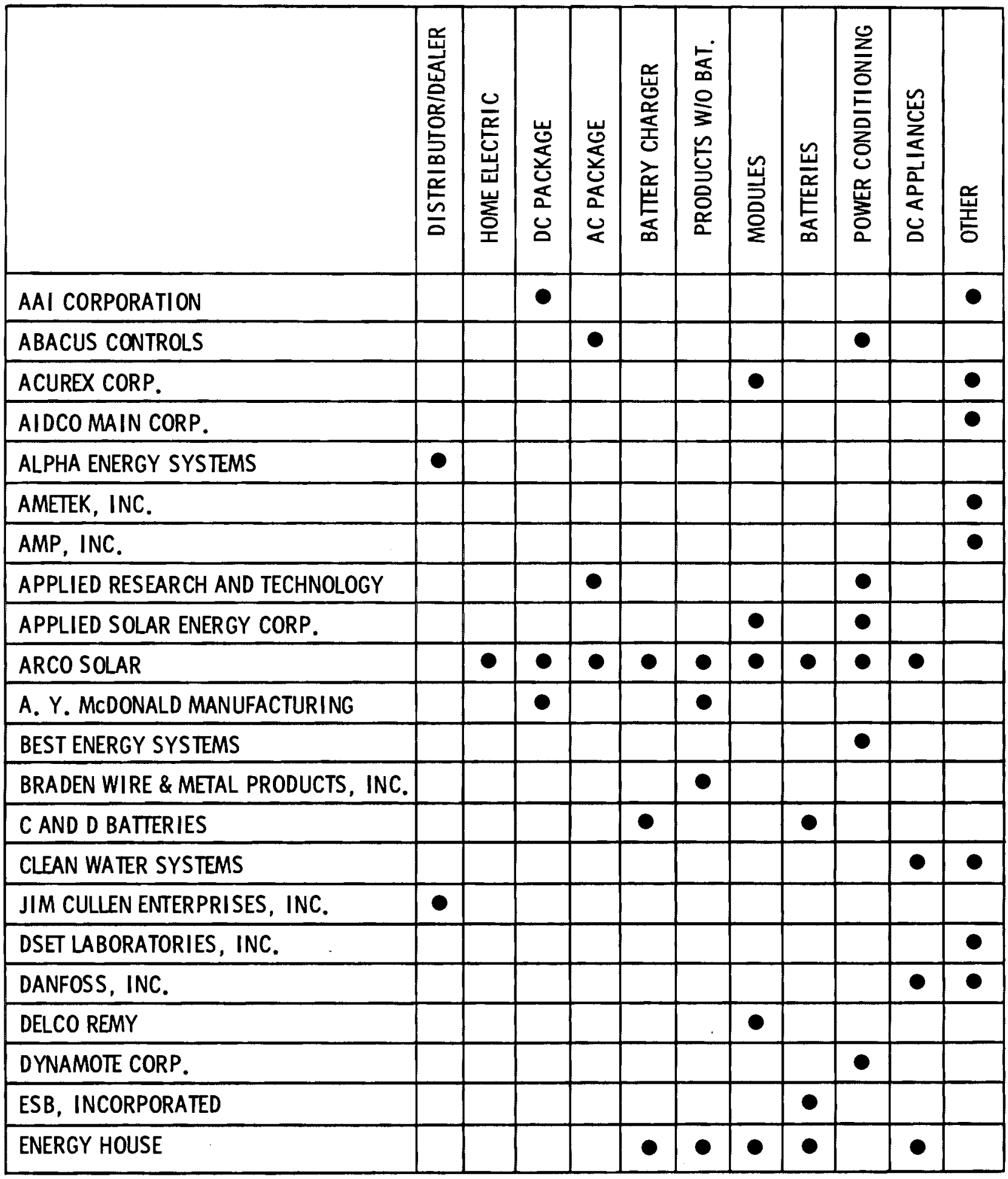




\begin{tabular}{|c|c|c|c|c|c|c|c|c|c|c|c|}
\hline & 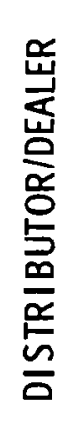 & 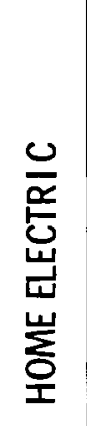 & 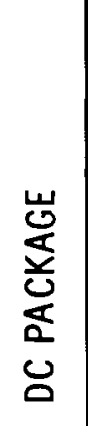 & 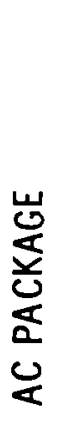 & 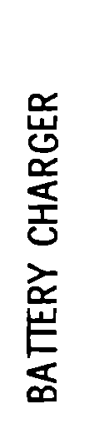 & 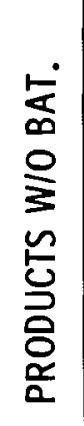 & $\begin{array}{l}\text { 岁 } \\
\text { 을 }\end{array}$ & 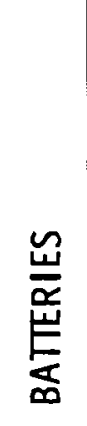 & 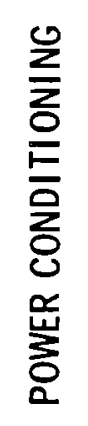 & 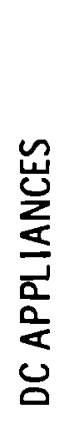 & $\begin{array}{l}\text { 壱 } \\
\text { 号 }\end{array}$ \\
\hline ENERGY UNLIMITED & & & & & - & & & & & $\bullet$ & \\
\hline ROGER ETHIER ASSOC. & & & & & & & & & & & $\bullet$ \\
\hline EXIDE CORP. & & & & & $\bullet$ & & & & & & \\
\hline FREE ENERGY SYSTEMS, INC. & & & $\bullet$ & $\bullet$ & & $\bullet$ & & $\bullet$ & $\bullet$ & $\bullet$ & $\bullet$ \\
\hline GATES ENERGY PRODUCTS & & & & & & & & & $\bullet$ & & \\
\hline GLASS ENERGY ELECTRONICS & - & & & & & & & & & & \\
\hline GLOBE-UNION, INC. & & & & & & & & - & & & \\
\hline HELIONETICS & & & & & & & & & $\bullet$ & & \\
\hline HYDROCAP CORP. & & & & & & & & $\bullet$ & & & \\
\hline INTERNATIONAL RECTIFIER & & & & & & & $\bullet$ & & & & \\
\hline IOTA ENGINEERING, INC. & & & & & & $\bullet$ & & & & & \\
\hline WILLIAM LAMB CO. & & & $\bullet$ & & & $\bullet$ & & & & $\bullet$ & \\
\hline LI-COR INC. & & & & & & & & & & & $\bullet$ \\
\hline MARCH MFG COMPANY & & & & & & & & & & $\bullet$ & \\
\hline MID PACIFIC SOLAR & & & & & & & $\bullet$ & & & & \\
\hline MILTON ROY & & & & & & $\bullet$ & & & & & \\
\hline MOBIL/TYCO SOLAR & & & & & & & $\bullet$ & & & & \\
\hline MONEGON LTD. & $\bullet$ & & & & & & & & & & \\
\hline MOTOROLA INC. & & & & & & $\bullet$ & $\bullet$ & & $\bullet$ & $\bullet$ & \\
\hline NATURAL POWER, INC. & & & & & & & & & & & 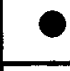 \\
\hline NOVA ELECTRIC & & & & & & & & $\bullet$ & - & & \\
\hline PARKER-MCCRORY MFG. COMPANY & & & & & & $\bullet$ & & & & & - \\
\hline
\end{tabular}




\begin{tabular}{|c|c|c|c|c|c|c|c|c|c|c|c|}
\hline & 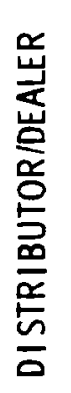 & 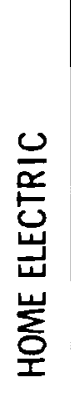 & 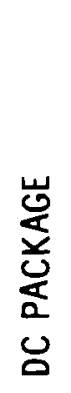 & 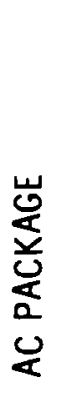 & 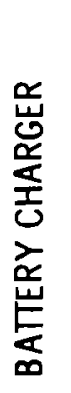 & 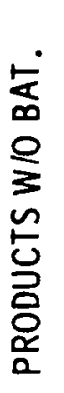 & 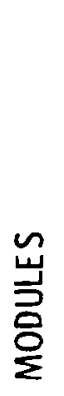 & 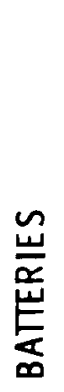 & 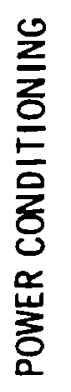 & 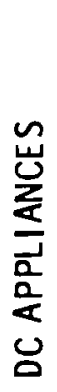 & $\begin{array}{l}\text { 䓌 } \\
\text { 夏 }\end{array}$ \\
\hline PENNWALT CORPORATIOI & & & & & & & 0 & & & & \\
\hline PHOTON POWER, INC. & & & & & & & - & & & & \\
\hline PHOTOVOLTAIC ENERGY & & & & & & & & & & & $\bullet$ \\
\hline PHOTOVOLTAICS INC. & & & & & & & & & & & $\bullet$ \\
\hline PHOTOWATT INTERNATIO & & & & & & - & - & & & & \\
\hline POWER SONIC CORP. & & & & & & & & $\bullet$ & & & \\
\hline RAIN BIRD INTERNATION & & & & & & - & & & & & \\
\hline REAL GAS \& ELECTRIC CO & & & & & & - & & & & & \\
\hline RENEWABLE ENERGY INST & & & & & & & & & & & $\bullet$ \\
\hline SES, INC. & & & & & & & $\bullet$ & & & & \\
\hline SIMICON, INC. & & & & & & & & & & & $\bullet$ \\
\hline SILICON SENSORS, INC. & & & & & & & - & & & & \\
\hline SILONEX & & & & & & & 0 & & & & \\
\hline SOLAR COMPONENTS COF & - & & & & & & & & & & \\
\hline SOLAR CONTRACTORS \& & & & & & & & & & & & 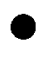 \\
\hline SOLAR DISC & & $\bullet$ & & & & & & & & & \\
\hline SOLAR MART & 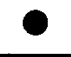 & & & & & & & & & & \\
\hline SOLAR POWER CORPORA & & & & & & & - & - & & & \\
\hline SOLAR USAGE NOW, INC & & & & & & - & & & & & \\
\hline SOLAR WAREHOU SE & & & & & & & & & & & 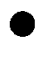 \\
\hline SOLAREX CORPORATION & $\bullet$ & - & - & 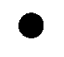 & $\bullet$ & $\bullet$ & - & & 0 & 0 & 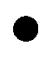 \\
\hline SOLARTHERM, INC. & & & & & & - & - & & & & \\
\hline SOLARWEST ELECTRIC & $\bullet$ & 0 & - & 0 & & $\bullet$ & 0 & $\bullet$ & 0 & • & 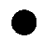 \\
\hline
\end{tabular}




\begin{tabular}{|c|c|c|c|c|c|c|c|c|c|c|c|}
\hline & 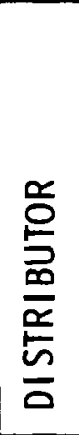 & 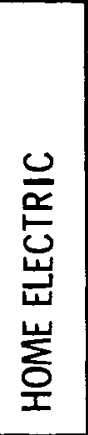 & 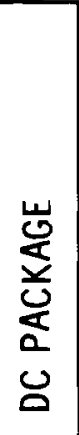 & 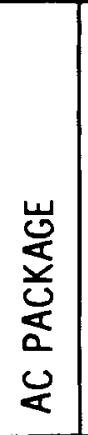 & 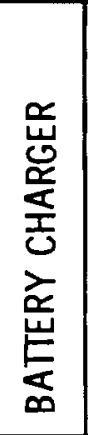 & 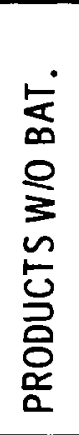 & $\begin{array}{l}\text { 㞻 } \\
\text { ○े } \\
\stackrel{0}{\Sigma}\end{array}$ & 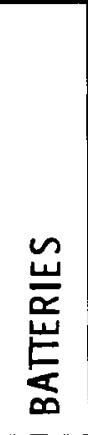 & 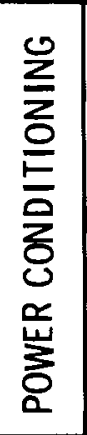 & 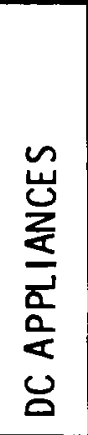 & 觅 \\
\hline SOLEC INTERNATIONAL, INC. & & & $\bullet$ & & $\bullet$ & & $\bullet$ & & & - & $\bullet$ \\
\hline SOLENERGY CORPORATION & & & & & & - & - & - & & & \\
\hline SOLLOS INC. & & & & & $\bullet$ & & - & & & & \\
\hline SPIRE CORPORATION & & & & & & & $\bullet$ & & & & 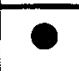 \\
\hline STANDARD SOLAR COLLECTORS, INC. & & $\bullet$ & & & & & & & & $\bullet$ & \\
\hline SURRETTE STORAGE BATTERY CO. & & & & & & & & $\bullet$ & & & \\
\hline TELEDYNE INET & & & & & & & & & $\bullet$ & & \\
\hline TIDELAND SIGNAL CORPORATION & & & - & & & & - & & & & \\
\hline TOPAZ, INC. & & & & & & & & & $\bullet$ & & \\
\hline TRI-SOLAR CORPORATION & & 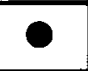 & $\bullet$ & & & $\bullet$ & & & & & \\
\hline UNITED ENERGY CORPORATION & & & & & 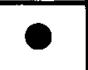 & & - & & - & - & \\
\hline WESTERN SOLAR REF. & & $\overline{0}$ & & & & & & & & 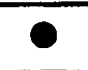 & \\
\hline WILLMORE ELECTRONICS CO. & & & & & & & & & - & & \\
\hline WINDWORKS & & & & & & & & & - & & \\
\hline ZOMEWORKS & & & & & & & & & & $\boldsymbol{0}$ & \\
\hline
\end{tabular}


APPENDIX IV

ADDRESS LIST 
AAI Corporation

Nick Kaplan

P0 Box 6767

Baltimore, MD 21204

(301) 628-3481

Abacus Controls, Inc.

F. Curtis Lambert

PO Box 893

Somerville, NJ 08876

(201) 526-6010

Acurex

Dariush Rafinejad

485 Clyde Avenue

Mountain View, CA 94042

(415) 964-3200

Advanced Energy Corporation

Gerry Gershenberg

14933 Calvert Street

Van Nuys CA 91411

(213) 728-2191

Aidco Main Corporation

R. Multer

Orr's Is land, ME 04066

(207) 833-6700

Alpha Energy Systems

George J. Bauer

120 East Kilgore Road

Kalamazoo, MI 49001

(616) $382-2532$

American Power Conversion Corp.

Ervin $F$. Lyon

89 Cambridge Street

Burlington, MA 01803

(617) 273-1570

Ametek, Inc. AVP Group

Robert A. Russe 11

1380 Welsh Road

Montgomeryville, PA 18936

(215) 647-2121
AMP, Incorporated

Edgar C. Gorman

Harrisburg, PA 17105

(717) $564-0100$

Applied Research and Technology of Utah (ARTU)

Robert W. McNamara

1918 North 90 West

Orem, UT 84057

(801) 224-2594

Applied Solar Energy Corp.

Thomas J. Brawley

PO Box 1212

City of Industry, CA 91749

(213) 968-6581

ARCO Solar

Photovoltaic Sales \& Marketing

Ms. Celine Herzing

20554 Plummer Street

Chatsworth, CA 91311

(213) 988-0667

Arco Solar

$\mathrm{Mr}$. George McClure

20554 Plummer Street

Chatsworth, CA 91311

Automatic Power, Inc. See Pennwalt

A.Y. McDonald

John D. Eckel

Energy Products Division

12th and Pine Street

Dubuque, IA 52001

(319) 583-7311, Ext. 227

Battelle

Pacific Northwest Laboratories

Raymond L. Watts

Sigma IV Bldg.

P.0. Box 999

Richland, WA 99352

(509) $376-4348$ 
Best Energy Systems

$\mathrm{Mr}$. Terrance D. Pau 1

Route 1, P0 Box 106

Necedah, WI 54646

(608) $565-7200$

Blue Sky Water Supply Co.

Ronald Shaw

PO Box 21359

Billings, MT 59104

(406) 259-0654

Braden Wire \& Metal Products, Inc. Martin L. Steger

PO Box 5087

San Antonio, TX 78201

(512) 734-5189

C \& D Batteries

R. N. Kauffman

Market Development Asst.

3043 Walton Road

Plymouth Meeting, PA 19462

(215) 828-9000, Ext 246

Clean Water Systems

Jack Cotter

15155 Stagg Street

Van Nuys, CA 91405

(213) $782-1207$

Jim Cullen Enterprises, Inc.

The Wilderness Home Power System

PO Box 732

Laytonville, CA 95454

(707) 984-6186

DSET Laboratories, Inc.

Ms. P.V. French

Box 1850, Black Canyon Stage

Phoenix, AZ 85029

(602) $465-7356$

Danfoss, Inc.

Stephen M. Madigan

16 Mckee Drive

Mahwah, NJ 07430

(201) $529-4900$

Delco Remy

D.L. "Sonny" Williams

2401 Columbus Avenue

Anderson, IN 46011

(317) $646-7404$
Dynamote Corp.

Stephen Handley

1200 West Nickerson

Seatt le, WA 98119

(206) $282-1000$

ESB Incorporated

2510 North Boulevard

Raleigh, NC 27604

(919) 834-8465

Energy House

Jack Zohar

P0 Box 848

Mercer Is land, WA 98040

(206) 236-0282

Energy Unlimited, Inc

Ted Gurniak

\#2 Aldwyn Center

Villanova, PA 19085

(215) $525-5215$

Roger Ethier Assoc.

205 Franklin Street

Alexander, VA 22314

(703) $683-2657$

Exide Corp. (Subsidiary of ESB)

Mr. Gene Cook

101 Gibraltar Road

Horsham, PA 19044

(215) 441-7482

Free Energy Systems, Inc.

Al Bakewe 11

Holmes Industrial Park

Holmes, PA 19043

(215) $583-4780$

Gates Energy Products

Mike Harrison

1050 S. Broadway

Denver, Co 80217

(303) 744-4806

General Electric

$\mathrm{Mr}$. Jim Marler

PO Box 8661, Room 114

Philadelphia, PA 19101

(215) $962-5835$ 
Glass Energy Electronics

Ron Wilson

4463 Woodland Park, Ave N.

Seattle, WA 98103

(206) 632-1645

Globe-Union, Inc.

Battery Division

Department $G$

Paul C. Bronesky

5757 North Green Bay Avenue

Milwaukee, WI 53201

(414) 228-2581

Helionetics

Delta Electronic Control Division

Stan Boyle

17312 Eastman Street

Irvine, CA 92714

(714) 546-4731

Honeywe 11 Motor Products

Roger Baird

PO Box 106

Rockford, IL 61105

(815) 966-3600

Hydrocap Corp.

George Peroni

975 N.W. 95th Street

PO Box 380698

Miami, FL 33150

(305) 696-2504

International Rectifier

Harold Weinstein

233 Kansas Street

E1 Segundo, CA 90245

(213) $322-3331$

Iota Engineering, Inc.

Sylvia D. Clayton

1735 E. Ft. Lowe 11 Rd., Suite 12

Tuscon, AZ 85719

(602) 327-5781

Koh ler Company

44 High Street

Kohler, WI
William Lamb Co.

10615 Chandler Blvd. North Hollywood, CA 91601

(213) 980-6911

LI-COR, Inc.

Photovoltaic Product Marketing

John Gewecke

PO Box 4425

Lincoln, NB 68504

(402) $467-3576$

March MFG Company

Mr. F. Ahline

1819 Pickwick Avenue

Glenview, IL 60025

(312) $729-5300$

Massachusetts Institute of

Technology Lincoln Laboratory

Marv Pope

PO Box 73

Lexington, MA 02173

Mid-Pacific Solar

Roberta Colvin

14202 Ventura Blvd.

Suite 101

Sherman Oaks, CA 91403

(213) 501-2988

Hartell Div Milton Roy

$\mathrm{Mr}$. Douglas Bingler

70 Industrial Drive

Ivyland, PA 18974

(215) 322-0730

Mobil/Tyco Solar

Mr. K. V. Ravi

16 Hickory Drive

Waltham, MA 02154

(617) 890-0909

Monegon LTD.

Mr. Harold L. Macomber

4 Professional Drive

Suite 130

Gaithersburg, MD 20760

(301) 840-0320 
Monegon LTD.

$\mathrm{Mr}$. Harold L. Macomber

4 Professional Drive

Suite 130

Gaithersburg, MD 20760

(301) 840-0320

Motorola, Inc.

Mr. Raymond Kenda 11

Solar Energy Dept.

5005 East McDowe 11 Road

PO Box 20924

Phoenix, AZ 85036

(602) 244-6900

NASA Lewis Research Center

Bill Brainard

21000 Brookpark Road

Cleveland, $\mathrm{OH} 44135$

Silonex Inc.

Dr. M. Pawlowsk i

Chief Engineer, Silicon Devices

331 Cornelia Street

Plattsburgh, NY 12901

(518) $561-3160$

Natural Power, Inc.

Brian Gordan

Francestown Turnpike

New Boston, NH 03070

(603) 487-5512

Norcold Incorporated

R.C. Matz

1510 Michigan Street

Sidney $\mathrm{OH} 45365$

(513) 492-1111

Nova Electric Man. Co.

Kenneth Niovitch

$263 \mathrm{Hillside} \mathrm{Ave.}$

Nutley, NJ 07110

(201) 661-3434

Pacific Energy Systems

Edward Delvers

427 E. Montecito Street

Santa Barbara, CA 93101

(805) 963-2155
Parmak

Parker-McCrory MFG. Company

Kenneth D. Turner

3175 Terrace Street

Kansas City, MO 64111

(816) $753-3175$

Pennwalt Corporation

Automatic Power Division

Robert Dodge

Hutchinson Street

Houston, TX 77002

(713) $228-5208$

Photon Power, Inc.

Mr. Martin Wenzler

10787 Gateway West

El Paso, TX 79935

(915) 593-2861

Photovoltaic Energy Systems, Inc.

Paul Maycock

2401 Childs Lane

Alexandria, VA 22308

(703) 780-7308

Photovoltaics, Inc.

Mr. Lawrence Curtin

1110 Brickle Avenue

Suite 430

Miami, FL 33131

(305) 374-2440

Photowatt Internationa 1, Inc.

George W. Lacey Jr.

2414 West 14th Street

Tempe, AZ 85281

(602) $894-9564$

Power Sonic Corp

Bruno A. Ender

Photovoltaic Marketing

P0 Box 5242

3106 Spring St

Redwood City, CA 94063

(415) 364-5001

Rain Bird International Inc.

Kenneth A. Ude

7045 North Grand Avenue

Glendora, CA 91740

(213) 963-9311 
Real Gas \& Electric Co.

James Weller

PO Box $F$

Santa Rosa, CA 95402

(707) $526-3400$

Renewable Energy Institute

John Wilson

1050 17th Street, NW, Suite 1100

Washington, D.C. 20036

(202) 822-9157

SES, Incorporated

Greg T. Love

Tralee Industrial Park

Newark, DE 19711

(302) 731-0990

Sandia Laboratories

Don Schueler

Division 4719

P.0. Box 5800

Albuquerque, NM 87115

(505) 844-4041

Semicon, Inc.

Robert A. Irvin

14 North Avenue

Burlington, MA 01803

(617) 272-9015

Silicon Sensors, Inc.

Ronald W. Ignatius

Highway 18 East

Dodgeville, WI 53533

(608) $935-2707$

Solar Components Corp.

Mr. Scott Keller

PO Box 237

121 Valley St

Manchester, NH 03105

(603) 668-8186

Solar Contractors \& Buildings, Inc. Mr. Michael Baker

8 Charles Plaza \# 805

Baltimore, MD 21201

(301) 727-6740
Solar Disc

Genos Colvin

540 Lagoon Drive

Honolulu, HI 96819

(808) 833-0001

Solar Energy Research Institute

Don Ritchie

1617 Cole Boulevard

Golden, C0 80401

(303) 231-1372

The Solar Mart

Division of McGill Stephens, Inc.

134 Vermont N.E.

Albuquerque, NM 87108

Solar Power Corporation

(Affiliate of Exxon Corp.)

C. William Clark

20 Cabot Road

Woburn, MA 01801

(617) $935-4600$

Solar Usage Now Inc.

Mr. Joseph Deah 1

Box 306

420 E. Tiffin Street

Bascam, OH 44809

(419) 937-2226

Solar Warehouse

Mr. Richard Brandt

140 Shrewsbury Ave

Red Bank, NJ 07701

Solarex Corporation

Ed Roberton

Marketing

1335 Piccard Drive

Rockville, MD 20850

(301) 948-0202

Solar General Store, Inc.

Bob Walker

445 Conger Lane

Garberville, CA 95440

(707) 923-3353 
Solartherm, Inc.

Carl Schleicher

1110 Fidler Lane

Silver Springs, MD 20910

(202) 882-4000

Solarwest Electric

Rob Robinson

232 Anacapa Street

Santa Barbara, CA 93101

(805) 963-9667

Solec Internationa1, Inc.

Robert F. Brown

12533 Chadron Avenue

Hawthorne, CA 90250

(213) 970-0065

Solenergy Corporation

Mr. Robert Willis

171 Merrimac St.

Woburn, MA 01801

(617) 938-0563

Sollos Inc.

Dr. Milo Macha

2231 Carmelina Avenue

Los Angeles, CA 90064

(213) 820-5181

Specialty Concepts

820 N. Lincoln Street

Burbank, CA 91506

Spire Corporation

Mr. Thomas Wilber

Patriots Park

Bedford, MA 01730

(617) 275-6000, Ext. 223

Standard Solar Collectors, Inc.

Claude Burly

1465 Gates Avenue

Brook lyn, NY 11385

(212) 456-1882

Surrette Storage Battery Co.

Po Box 3027

Salem, MA 01970

(617) 745-4444

Teledyne Inet

Fred Tamjidi

2750 West Lomita Blve.

Torrance, CA 90509

(213) $325-5040$
Tideland Signal Corporation

Carl Kotila

4310 Directors Row, Box 52430

Houston, TX 77052

(713) 681-6101

TriSolarCorp

Mr. Ron Matlin

10 DeAnge 10 Drive

Bedford, MA 01730

(617) $275-1200$

Topaz, Inc.

Powermark Division

Chuck Parker

3855 Ruffin Road

San Diego, CA 92123

(714) $565-8363$

United Energy Corporation

Bill Edwards

1176-D Aster Avenue

Sunnyvale, CA 94086

(408) 243-0330, or

PO Box 31089

Honolulu, HI 96820

(808) $836-1593$

Western Solar Refrigeration, Inc.

Ronald L. Strathman

715 "J" Street

San Diego, CA 92101

(714) 235-6002

Willmore Electronics Co.

Photovoltaics Products

Chris Ely

PO Box 1329

Hillsborough, NC 27278

Windworks

Thomas Werking

Box 44A, Route 3

Mukawongo, WI 53149

(414) 363-4088

Wisco Division, ESB Incorporated

$\mathrm{Mr}$. Jerry Fox

2510 North Boulevard

Raleigh, NC 27604

(919) 834-8465

Zomeworks

P0 Box 712

Albuquerque, NM 87103

(505) 242-5354 


\section{DISTRIBUTION}

No. of

Copies

\section{OFFS ITE}

27 DOE Technical Information

A. A. Churm

DOE Patent Division

9800 South Cass Avenue

Argonne, I11inois 60439

Andrew Krantz

Department of Energy

Forrestal Building

Washington, D.C. 20056

Dr. Morton B. Prince

Department of Energy

Forrestal Building

Washington, D.C. 20056

Lee Barrett

Photovoltaic Energy Technology Division

Department of Energy

600 E. Street, N.W.

Washington, D.C. 20585

99 See Address List Appendix IV, PG IV-1 through IV-6.

Aerospace Corporation

Stan ley Leonard

PO Box 92957

Los Angeles, CA 95081
No. of

Copies

Jet Propulsion Laboratory

Elmer Christensen

4800 0ak Grove Drive

Pasadena, CA 91103

Mary Cumminskey

Solar Age Magazine

Church $\mathrm{Hi} T$

Harrisville, NH 03450

Jack Dodd

OMB Room 8002

New Executive Office Building

726 Jackson Place, N.W.

Washington, D.C. 20503

ONSITE

DOE Richland Operations Office

H. E. Ransom

24 Pacific Northwest Laboratory

R. L. Watts (4)

S. A. Smith (3)

R. P. Mazzucchi

W. E. Gurwe 11

C. H. B Toomster

D. E. Deonigi

L. D. Williams

Economics Library (3)

Technical Information (5)

Publishing Coordination (2) 
